\title{
24. RADIOLARIA, LEG 4, DEEP SEA DRILLING PROJECT
}

W. R. Riedel and Annika Sanfilippo

Scripps Institution of Oceanography, La Jolla, California

\section{CONTENTS}

1. Introduction

504

2. Cretaceous occurrences

504

3. Cenozoic zonation

505

4. Definition of Cenozoic radiolarian zones 511

5. Correlation of microfossil zonations $\quad 513$

6. Cenozoic Radiolaria in the drill-cores 513

Site 29

Site 27,28

Site 31

Site 30

7. Systematic section (Cenozoic forms)

8. Evolutionary lineages

9. References

10. Explanation of Plates

540

11. Index of radiolarian names 


\section{INTRODUCTION}

As is indicated in the general description of the cores (Chapters 2-10 of this volume), radiolarians occur in Cretaceous deposits at Sites 24 and 28, in Eocene deposits at Sites 27, 28 and 29, possibly in Oligocene deposits at Site 27, and in Miocene deposits at Sites 30 and 31. Most of these occurrences are in short, isolated core sections, but the Eocene section at Site 29 provides a long sequence of highly radiolarian sediment which permits a fundamental advance in our understanding of the biostratigraphy of this microfossil group.

Stratigraphic correlation by means of radiolarians is not yet as routine a matter as it is with foraminifera and calcareous nannoplankton and, therefore, it has not been possible to provide simple lists of well-known species in other sections of this volume to substantiate the age-assignments indicated. Instead, all information on the occurrences of species is given in this present chapter, together with information necessary to justify the correlations.

In order to describe the stratigraphic positions of the radiolarian sediments obtained on Leg 4, it is necessary to provide an outline of a Cenozoic radiolarian zonation, the details of which are being prepared for publication elsewhere. In the outline of radiolarian zonation presented below, the approximate relation of calcareous microfossil zones to radiolarian zones is indicated wherever possible. It has been necessary to describe a number of new taxa in order to facilitate discussion of the zonation and evolutionary series, and generic assignments of some previously known species are changed to bring them into conformity with a system of classification believed to be more natural than Haeckel's (Riedel, 1967 and in press, a).

Much of the research leading to the development of the Cenozoic radiolarian zonation applied in this report has been supported by the Office of Naval Research Contract Nonr 2216(23) and National Science Foundation Grants GA-11489 and GA-658. The latter grant also made possible some progress toward the intercorrelation of foraminiferal, nannofossil and radiolarian zonations.

The authors are indebted to many colleagues throughout the world for providing samples from land-based sections which have been used in the development of the radiolarian taxonomy and stratigraphy.

\section{CRETACEOUS OCCURRENCES}

Sediments containing Cretaceous radiolarians were cored at Sites 24 and 28: At Site 24 (Cores 1 to 4 of Hole 24A) they occur from about 500 to about 560 meters (1640 to 1836 feet) below the sea floor, becoming progressively sparser and less well preserved downward, and at Site 28 they occur in only one sample at about 400 meters (1312 feet) below the sea floor.

Hole $24 \mathrm{~A}\left(6^{\circ} 16.58^{\prime} \mathrm{S}, 30^{\circ} 53.46^{\prime} \mathrm{W}\right.$; water depth 5148 meters)

\section{Sample 24A-1-1:}

The assemblage here is diverse and well preserved, and therefore most of the specimens illustrated from this hole are from this sample. The radiolarian preparations contain a large amount of fish skeletal debris (placoid scales?). The age, to judge from previous records of some of the species, is Upper Cretaceous, probably Campanian.

Below we list some of the commoner and more striking members of the assemblage. At this site there were no representatives of the families: Collosphaeridae Müller, Phacodiscidae Haeckel, Coccodiscidae Haeckel, Acanthodesmiidae Haeckel, Carpocaniidae Haeckel emend. Riedel, Pterocoryidae Haeckel emend. Riedel, or Cannobotryidae Haeckel emend. Riedel, probably because these families had not yet evolved.

Family ACTINOM MIDAE Haeckel 1862, emend. Riedel 1967b:

A spherical form with medullary shell and two (rarely more) strong, bladed spines, and cortical shell with tuberose surface and small pores is illustrated (Plate 1, Figure 1).

Subfamily SATURnALINAE Deflandre 1953: In addition to common fragments of saturnalin rings with many spines (Plate 1, Figure 3), there rarely occurs a form with two half-rings joined directly to the shell (c.f. Saturnalis minimus Squinabol, 1914, p. 287, Plate 22, Figure 1; Plate 23, Figure 6; originally described from the Jurassic and Middle Cretaceous of Italy); Plate 1, Figure 2.

Family SPONGODISCIDAE Haeckel 1862, emend. Riedel 1967b:

A number of forms occur, which are evidently related to species that have commonly been assigned to $\mathrm{Am}$ phibrachium Haeckel. The form illustrated in Plate 1, Figures 4 and 5 is comparable with $A$. ornatum Lipman (1960, p. 126, Plate 28, Figures 10 through 13), and that illustrated in Plate 1, Figures 6 and 7 resembles Amphibrachium concentricum Lipman (1960, p. 125, Plate 28, Figures 6 and 7); these species have been recorded from the Santonian-Campanian and Turonian of Western Siberia. There is also a simple, elongated form with two bladed spines in the main axis (Plate 1, Figure 8).

A form with a concentrically chambered circular disc and three strong marginal spines (Plate 1, Figure 9) occurs rather commonly. 
There is also a form (Plate 2, Figure 1) resembling Septinastrum dogeli Gorbovets (in Kozlova and Gorbovets, 1966, p. 86, Plate 4, Figures 4 and 5), recorded from the upper Campanian of Western Siberia, and one (Plate 2, Figure 2) apparently identical with Spongopyle insolita Kozlova (in Kozlova and Gorbovets, 1966, p. 91, Plate 4, Figures 11a and b), recorded from the Campanian of the eastern slope of the Urals.

A three-rayed form (Plate 2, Figure 3) may be identical with Euchitonia triradiata Lipman (1960, p. 129, Plate 29 , Figures 1 through 3 ), recorded from the SantonianCampanian of Western Siberia, but for a four-rayed form with a pronounced radial structure (Plate 2, Figure 4) it is impossible at present to make a satisfactory generic assignment.

Family PSEUDOAULOPHACIDAE Riedel 1967a: There are rare examples of a triangular pseudoaulophacid (Plate 2, Figure 5) resembling "Theodiscus" superbus Squinabol (1914, p. 271, Plate 20, Figure 4; recorded from the "Middle Cretaceous" of Italy) or Pseudoaulophacus gallowayi (White) (Pessagno, 1963, p. 202, Plate 2, Figures 1, 3 and 6; Plate 4, Figures 2, 5 and 7; Plate 7, Figures 2 and 4; recorded from the Campanian of Puerto Rico and Mexico), and common three-and four-rayed forms (Plate 2, Figures 6 and 7) in which the central portion tends to have a pseudoaulophacid structure and the arms a hagiastrin structure (Riedel, in press, a).

\section{Family THEOPER IDAE Haeckel 1881, emend.} Riedel 1967b:

There are rather few specimens (Plate 3, Figure 1) of a Theocapsomma (in the sense of Foreman, 1968, p. 29) resembling Tricolocapsa granti Campbell and Clark (1944b, p. 35, Plate 7, Figures 37 and 38; recorded from the early Maestrichtian or perhaps late Campanian of California) or Theocapsa salva Rüst $(1888$, p. 210 , Plate 28, Figure 5; 1892, p. 107, Plate 15, Figure 3).

A common form (Plate 3, Figure 2) with enclosed cephalis and very constricted mouth resembles Dicolocapsa verbeeki Tan Sin Hok (1927, p. 44, Plate 8, Figures 40 and 41; Gongylothorax verbeeki in Foreman, 1968, Plate 2, Figure 8; recorded from the Turonian or early Senonian of Indonesia and from the Santonian-Campanian to Maestrichtian of Cuba and California), but appears not to have a differentiated pore or tube in the thoracic wall near its junction with the cephalis.

There are a number of other theoperids which are illustrated but which cannot readily be compared with described species - a form probably assignable to Cornutella (Plate 3, Figure 3); a three-segmented form with rather large cephalis, inflated thorax and narrower abdomen (Plate 3, Figure 4); a rare form with strong, bladed feet and horn, and lamellar, sparsely perforate thorax (Plate 3, Figure 5); forms evidently related to Sciadiocapsa (Plate 3, Figures 6 and 7); and, common representatives of Dictyomitra with and without longitudinal ribs (Plate 3, Figures 8 through 10).

Family AM PHIPYNDACIDAE Riedel, 1967a:

This family is represented by a form (Plate 3 , Figure 11) with generally two or three transverse rows of pores on each segment, bearing some resemblance to Dictyomitra uralica Gorbovets (in Kozlova and Gorbovets, 1966, p. 116, Plate 6, Figures 6 and 7; recorded from the Campanian of Western Siberia) and Amphipyndax stocki (Campbell and Clark)-(Foreman, 1968, p. 78, Plate 8, Figures 12 a-c; recorded from Santonian to Paleocene of the Caribbean region and California).

Family A RTOSTROBIIDAE Riedel, 1967a:

There are two common species in this assemblage, one (Plate 3, Figure 12) resembling Theocampe mongolfieri (see section on Cenozoic radiolarians) but with abdominal pores less numerous and not in such pronounced longitudinal and transverse rows, and the other (Plate 3 , Figure 13) with a rough abdominal surface and flared peristome. This latter form occurs in the Santonian-Campanian of Cuba (Sample B191 of P. J. Bermudez; for locality see Foreman, 1966, p. 358) and is not known elsewhere.

Samples 24A-3-1, 78-80 cm; 24A-3-1, 87-89 cm; 24A-3-1, 136-138 cm;24A-3-1, 138-140 cm; 24A-4-1; 24A-4-2, 10-12 cm; 24A-4-2, 20-22 cm; 24A-4-2, 30-32 cm; and, 24A-4-2, 136-138 cm:

The radiolarian assemblages in these samples are sparser than those in Sample 24A-1-1, but appear not to differ markedly from it in species content.

Site $28\left(20^{\circ} 35.19^{\prime} \mathrm{N}, 65^{\circ} 37.33^{\prime} \mathrm{W}\right.$; water depth 5521 meters)

\section{Sample 28-9-Core Catcher:}

Rather few, moderately well preserved radiolarians. Small, nondescript spongodiscids constitute the major part of the assemblage, and there are a few pseudoaulophacids, small artostrobiids somewhat resembling Theocampe mongolfieri in general form, Dictyomitra spp. (some multicostate), and rare specimens of the genus Holocryptocapsa Tan Sin Hok. The assemblage is probably Upper Cretaceous in age.

\section{CENOZOIC ZONATION}

The three summary tables (Figures 1,2 and 3) present a zonation of Cenozoic radiolarians, as a framework for the stratigraphic interpretation of the assemblages sampled on Leg 4. The middle Eocene zonation is based on the results from Site 29, the late Eocene zonation 


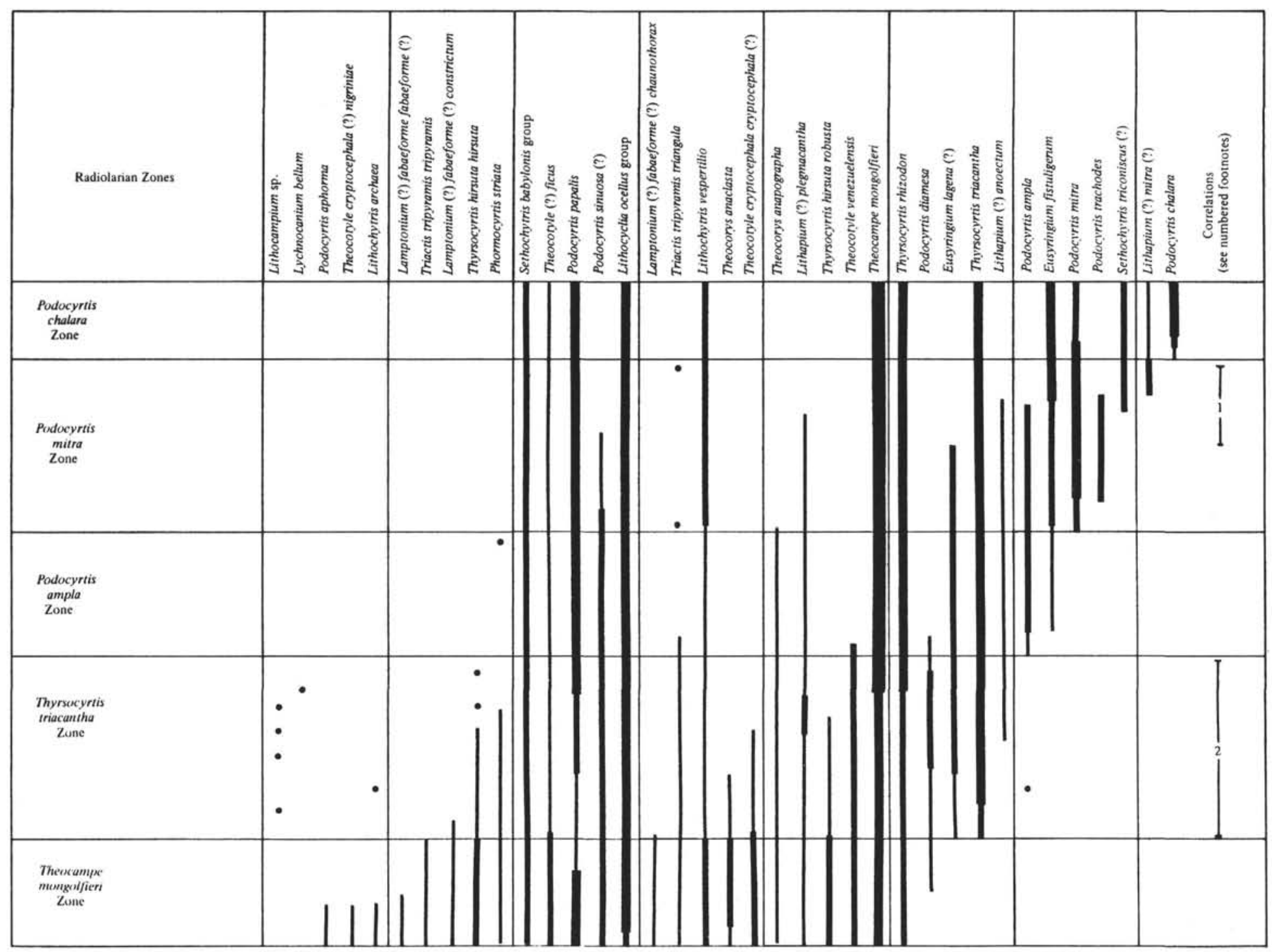

'DODO 123D. Early or middle Middle Eocene (B.M.Y. M.N.B.).

${ }^{2}$ DW BG 23B. Possibly Hanikeninu aragunensis Zone or bottom of Globigcrapsis kugieri Zone (Riedel and Funnell, 1964. p. 327).

Figure 1. Zonation of middle Eocene radiolarians. 


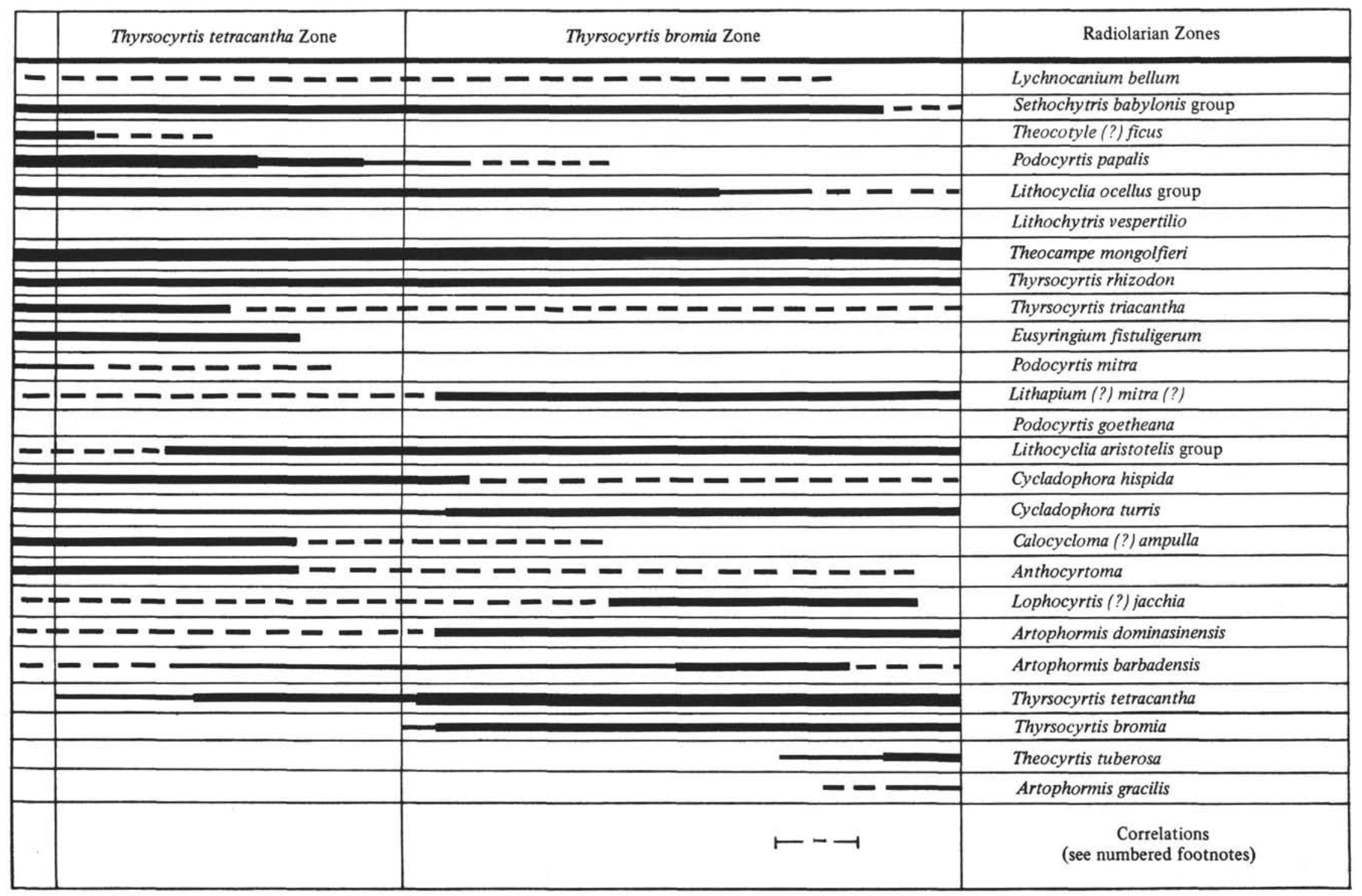

${ }^{1}$ JS 1077, Oceanic Formation, Bath, Barbados, Isthmolithus recurvus zone (Hay et al, 1967, fig. 8).

Figure 2. Zonation of late Eocene radiolarians 


\begin{tabular}{|c|c|c|c|c|c|c|c|c|}
\hline 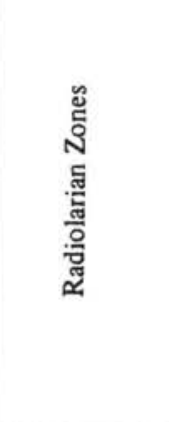 & 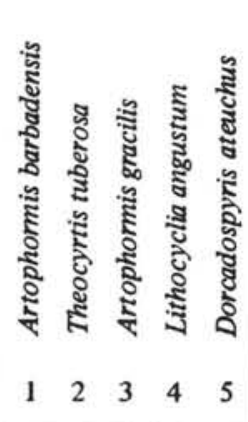 & 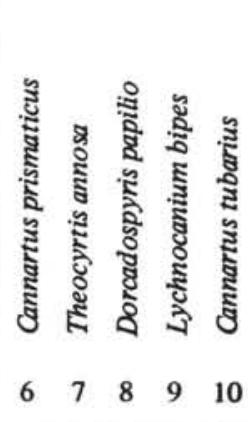 & 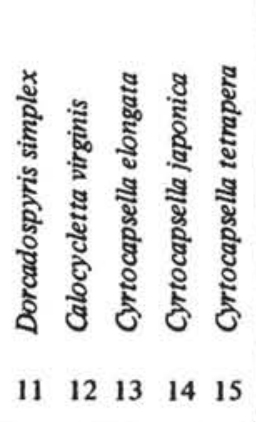 & 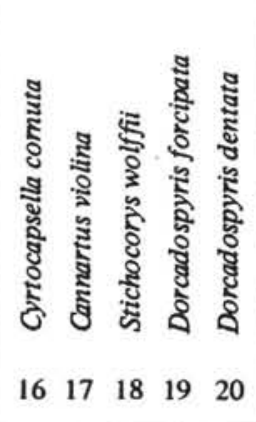 & 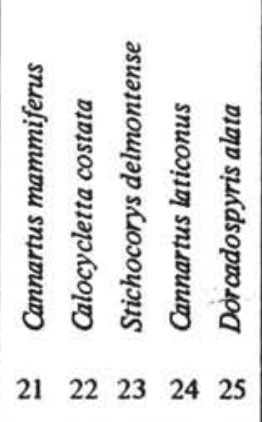 & 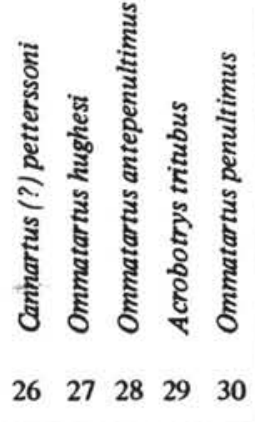 & 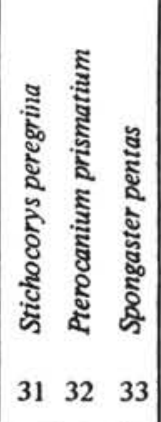 & 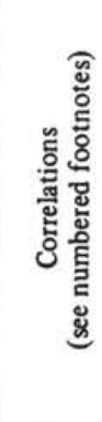 \\
\hline Quaternary & & & & & & & & \multirow{5}{*}{ 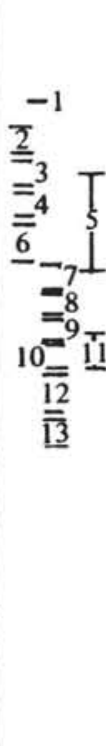 } \\
\hline $\begin{array}{l}\text { Pterocanium } \\
\text { prismatium } \\
\text { Zone }\end{array}$ & & & & & & & & \\
\hline $\begin{array}{l}\text { Spongaster } \\
\text { pentas } \\
\text { Zone }\end{array}$ & & & & & & & & \\
\hline $\begin{array}{l}\text { Stichocorys } \\
\text { peregrina } \\
\text { Zone }\end{array}$ & & & ? & ? & & & & \\
\hline $\begin{array}{l}\text { Ommatartus } \\
\text { penultimus } \\
\text { Zone }\end{array}$ & & & ? & $?$ & & & & \\
\hline
\end{tabular}

Figure 3. Zonation of Oligocene and Neogene radiolarians. 


\begin{tabular}{|l|l|l|l|l|l|l|l|l|l|l|}
\hline $\begin{array}{c}\text { Ommatartus } \\
\text { antepenul. } \\
\text { timus Zone }\end{array}$ \\
\hline $\begin{array}{c}\text { Cannartus (?) } \\
\text { petterssoni } \\
\text { Zone }\end{array}$
\end{tabular}

Figure 3. (Continued). 
${ }^{1} \mathrm{CAP} 38 \mathrm{BP}, 415$ centimeters. Earliest occurrence of Globorotalia truncatulinoides (F.L.P.).

2 SDSE 62, 1197-1210 centimeters. High in Zone N.21 (F.L.P.).

3 SDSE 58, 900-902 centimeters. Near middle of Zone N.21 (F.L.P.).

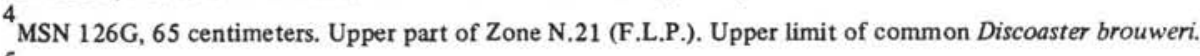

${ }^{5}$ SDSE 58, 984-986 centimeters. Zone N.21 (Blow, 1969, p. 306).

${ }^{6}$ CAP 38BP, approx. 500 centimeters. Lower part of Zone N.21; latest occurrence of Globigerinoides obliquus (F.L.P.).

${ }^{7}$ AMPH 37P, 250 centimeters. Lower part of Zone N.21 (F.L.P.). Upper limit of common Discoaster pentaradiatus.

${ }^{8}$ SDSE 62,1450 centimeters. Zone N.20 (F.L.P.).

${ }^{9}$ AMPH 37P, 350 centimeters. Approx. Zone N.19; latest occurrence of Globigerina nepenthes (F.L.P.).

${ }^{10}$ AMPH 37P, 450 centimeters. Lower part of Zone N.19 (F.L.P.). Latest occurrence of Ceratolithus tricorniculatus.

${ }^{11}$ LSDH 78P, 98-100 centimeters. Zone N.19 (Blow, 1969, p. 309). Lower part of Zone N.19 (F.L.P.).

12 LSDH 78P, 513-522 centimeters. Zone N.18 (F.L.P.). Earliest occurrence of Ceratolithus nugosus.

${ }^{13}$ LSDA 101G, 38 centimeters. Zone N.17 or 18 (Parker, 1967, p. 131).

14 RIS 12G, 13-19 centimeters. Zone N.18 (Blow, 1969, p. 306).

15 PROA 88P, 275 centimeters. Zone N.16 (Parker, 1967, p. 134).

${ }^{16}$ EM 8-11, 70-72 centimeters. Zone N.15 (W.H.B.).

${ }^{17}$ EM 7-1, 14-16 centimeters. Zone N.12 (W.H.B.).

${ }^{18}$ AMPH 6P, 15-17 centimeters. Zone N.11 (Blow, 1969, p. 308).

${ }^{19}$ AMPH 6P, 58-60 centimeters. Zone N.10 (Blow, 1969, p. 308).

${ }^{20}$ WR TR 11 Low (Bo. 202). Type locality of Globorotalia fohsi barisanensis Zone (Bolli, 1957, p. 101). Sphenolithus heteromorphus Zone (Bramlette and Wilcoxon, 1967, Table 1 and 2).

${ }^{21}$ SDSE 91, 319-320 centimeters. Zone N.9 (Blow, 1969, p. 311).

${ }^{22}$ WR TR 23 (K. 9391). Radiolarian-rich facies of the Globigerinatella insueta Zone near the Retrench trig. station, Golconda Estate, Trinidad (Bolli, 1957, p. 101).

${ }^{23}$ SDSE 91, 409-410 centimeters. Zone N.8 (Blow, 1969, p. 311).

${ }^{24}$ TTOC 178888. Helicosphaera ampliaperta Zone (Bramlette and Wilcoxon, 1967, Table 1 and 2).

${ }^{25}$ SDSE 91, 820-821 centimeters. Zone N.7 (Blow, 1969, p. 311).

${ }^{26}$ SDSE 91, 1209-1210 centimeters. Zone N.6 (Blow, 1969, p. 311).

27 CHUB 15, 78-82 centimeters. Approximate Catapsydrax stainforthi Zone (F. L. Parker in Riedel, 1959, p. 285).

${ }^{28}$ WAH 7P, $257-259$ centimeters. Zone N.5 (Blow, 1969, p. 311).

${ }^{29}$ WAH 7P, 519-521 centimeters. Zone N.4 (Blow, 1969, p. 311).

${ }^{30}$ CHUB 17, 11-15 centimeters. Approximate Globorotalia kugleri Zone (F. L. Parker in Riedel, 1959, p. 285). Zone N.4 (Blow, 1969, p. 308).

${ }^{31}$ DW BG 10, 13-15 centimeters. Probably Globorotalia kugleri Zone (Riedel and Funnell, 1964, p. 326). Zone N.4 (Blow, 1969, p. 308).

${ }^{32}$ RIS 111P, 280-282 centimeters. Zone N.4 (W.H.B.).

${ }^{33}$ JOIDES (Blake Plateau) 3358 feet (1023 meters). Sphenolithus predistentus Zone (Bramlette and Wilcoxon, 1967, Table 2).

${ }^{34}$ MP 5-1, 26-27 centimeters. Zone P.18 (Blow, 1969, p. 291).

${ }^{35}$ WR TR 39F (JS 1068). Just above top of Isthmolithus recurvus Zone (Hay et al., 1967, Figure 8). 
is based on the exposure of the Oceanic Formation at Bath Cliff, Barbados, and the Oligocene and Neogene zonation is a synthesis of results from many deep-sea cores and outcrops on land. The information forming the basis for Figure 1 will be found in Table 1 of this paper, while that forming the basis for Figures 2 and 3 will be presented in separate papers (in preparation). Because the Eocene zonation is based on two single sections and the later zonation is a patchwork, it is likely that the sequence will require modification when additional information becomes available; but, nevertheless, it seems possible to apply this draft at the present stage. Thicknesses of the middle and late Eocene zones are shown in approximately the same proportions in Figures 1 and 2 as they are in the lithologically rather uniform sequences at Site 29 and Bath Cliff, respectively. There is at present, however, no sufficient basis for estimating the relative durations of the zones shown in Figure 3.

In the figures, the relative abundances of species (abundant, common, few, rare) are indicated by the thicknesses of the vertical bars; intermittent rare occurrences are indicated by dashed lines, and isolated occurrences of individual specimens by dots. The tabulated species are arranged approximately in the order of their first appearances, with the earlier forms on the left and the later ones on the right. If species are not carried from one tabulation to the next (from Figure 1 to Figure 2, and from Figure 2 to Figure 3), this is because they do not occur in the younger assemblages. Cycladophora hispida, Calocycloma (?) ampulla and Anthocyrtoma are not included in Figure 1 or Table 1, although they occur through the entire middle Eocene section at Site 29.

The footnotes to Figures 1 through 3 present interpretations resulting from the examination of calcareous microfossils in some of the radiolarian samples, mainly by M. N. Bramlette, F. L. Parker, B. M. Funnell, W. H. Blow and H. M. Bolli. Initials of these workers in the footnotes to Figures 1,2 and 3 indicate personal communications from them. Where no such initials (or bibliographic references) are given the correlations are based on investigations by the present authors. Ranges of uncertainty in the correlations are indicated. Many of the samples used to interrelate the radiolarian zonation with those of the calcareous microfossils are from deep-sea sediment cores, and their locations may be found either in the published papers referred to or in Riedel (in press, b).

\section{DEFINITION OF CENOZOIC RADIOLARIAN ZONES}

As far as possible, the division into zones is here made in accordance with the following principles:

a) The base of each zone is defined by the first occurrence of a taxon that is easily recognizable, of known ancestry, of wide geographic distribution, and represented by numerous specimens in the assemblages in which it occurs.

b) Each zone should include the first or last occurrences of several taxa - i.e., should be a concurrent range zone. Because of this, and because some taxa undergo considerable morphologic evolution within zones, it may be possible in some cases to correlate remote samples with the upper, middle or lower part of some of the zones defined here.

\section{Theocampe mongolfieri Zone:}

Base is defined by the earliest evolutionary appearance of Theocampe mongolfieri. The zone includes the latest occurrences of Podocyrtis aphorma, Theocotyle cryptocephala (?) nigriniae, Lithochytris archaea and Lamptonium (?) fabaeforme fabaeforme (?), and the earliest evolutionary appearance of Podocyrtis diamesa. The top of the zone is coincident with the base of the Thyrsocyrtis triacantha Zone.

\section{Thyrsocyrtis triacantha Zone:}

Base is defined by the earliest appearance of Thyrsocyrtis triacantha, which is approximately synchronous with the earliest appearance of Eusyringium lagena (?) and the latest occurrences of Triactis tripyramis tripyramis and Lamptonium (?) fabaeforme (?) chaunothorax. The zone includes the latest occurrences of Lamptonium (?) fabaeforme (?) constrictum, Thyrsocyrtis hirsuta hirsuta, Theocorys anaclasta, Theocotyle cryptocephala cryptocephala (?) and Thyrsocyrtis hirsuta robusta, and the earliest appearance of Lithapium (?) anoectum. The top of the zone is coincident with the base of the Podocyrtis ampla Zone.

\section{Podocyrtis ampla Zone:}

The base is defined by the earliest evolutionary appearance of Podocyrtis ampla. The zone includes the latest occurrences of Theocotyle venezuelensis and Podocyrtis diamesa, and the earliest evolutionary appearance of Eusyringium fistuligerum. The top of the zone is coincident with the base of the Podocyrtis mitra Zone.

\section{Podocyrtis mitra Zone:}

The base is defined by the earliest evolutionary appearance of Podocyrtis mitra, which is approximately coincident with the latest occurrence of Theocorys anapographa. The zone includes the latest occurrences of Podocyrtis sinuosa (?), Lithapium (?) plegmacantha, Eusyringium lagena (?), Lithapium (?) anoectum and Podocyrtis ampla, the total range of Podocyrtis trachodes, and the earliest evolutionary appearances of Sethochytris triconiscus (?) and Lithapium (?) mitra (?). The top of the zone is coincident with the base of the Podocyrtis chalara Zone. 
Podocyrtis chalara Zone:

Base is defined by the earliest evolutionary appearance of Podocyrtis chalara. The top of the zone is not yet defined, but it may prove that the earliest evolutionary appearance of Podocyrtis goetheana will provide a suitable datum.

Regarding the unzoned interval, between the top of the radiolarian section represented at Site 29 and the base of Thyrsocyrtis tetracantha Zone, this interval is probably represented at the bottom of the Oceanic Formation on Barbados, where the radiolarians are poorly preserved in all samples available to us.

\section{Thyrsocyrtis tetracantha Zone:}

Base is defined by the earliest evolutionary appearance of Thyrsocyrtis tetracantha. The zone includes the last occurrences of Podocyrtis mitra, Theocotyle (?) ficus and Eusyringium fistuligerum, and perhaps the last occurrence of Podocyrtis goetheana. The top of the zone is coincident with the base of the Thyrsocyrtis bromia Zone.

\section{Thyrsocyrtis bromia Zone:}

Base is defined by the earliest appearance of Thyrsocyrtis bromia. The zone includes the last occurrences of Lychnocanium bellum, Podocyrtis papalis, Calocycloma (?) ampulla and the genus Anthocyrtoma, and the earliest evolutionary appearance of Artophormis gracilis. The top of the zone is coincident with the base of the Theocyrtis tuberosa Zone.

\section{Theocyrtis tuberosa Zone:}

Base is defined by the earliest appearance of Lithocyclia angustum. The zone includes the earliest occurrences of Cannartus prismaticus and Theocyrtis annosa. The top of the zone is coincident with the base of the Lychnocanium bipes Zone.

Lychnocanium bipes Zone:

The base is defined by the earliest appearance of Lychnocanium bipes, which is approximately synchronous with the earliest appearances of Dorcadospyris papilio and Cannartus tubarius. The zone includes the latest occurrences of Lithocyclia angustum, Theocyrtis annosa and Dorcadospyris papilio. The top of the zone is coincident with the base of the Calocycletta virginis Zone.

\section{Calocycletta virginis Zone:}

The base is defined by the earliest appearance of Calocycletta virginis, which is approximately synchronous with the latest occurrence of Artophormis gracilis and the earliest appearance of Dorcadospyris simplex, Cyrtocapsella elongata, C. japonica, C. tetrapera, C. cornuta and Cannartus violina. The zone includes the latest occurrence of Dorcadospyris ateuchus and the earliest appearance of Stichocorys wolffii, Dorcadospyris forcipata and $D$. dentata. The top of the zone is coincident with the base of the Calocycletta costata Zone.

\section{Calocycletta costata Zone:}

Base is defined by the earliest evolutionary appearance of Calocycletta costata, which is approximately synchronous with the latest occurrence of Cannartus prismaticus and the earliest appearances of Cannartus mammiferus and Stichocorys delmontensis. The zone includes the latest occurrences of Lychnocanium bipes and Cyrtocapsella elongata. The top of the zone is coincident with the base of the Dorcadospyris alata Zone.

\section{Dorcadospyris alata Zone:}

Base is defined by the earliest evolutionary appearance of Dorcadospyris alata, which is approximately synchronous with the latest occurrences of Cannartus tubarius, Dorcadospyris simplex, Stichocorys wolffii and Dorcadospyris forcipata. The zone includes the latest occurrences of Dorcadospyris dentata and Cannartus mammiferus. The top of the zone is coincident with the base of the Cannartus laticonus Zone.

\section{Cannartus laticonus Zone:}

The base is defined by the latest occurrence of Dorcadospyris alata, which is approximately synchronous with the latest occurrences of Calocycletta virginis and $C$. costata. The top of the zone is coincident with the base of the Cannartus (?) petterssoni Zone.

\section{Cannartus (?) petterssoni Zone:}

Base is defined by the earliest evolutionary appearance of Cannartus (?) petterssoni. The zone includes the earliest appearance of Ommatartus hughesi. The top of the zone is coincident with the base of the Ommatartus antepenultimus Zone.

\section{Ommatartus antepenultimus Zone:}

Base is defined by the earliest evolutionary appearance of Ommatartus antepenultimus, which is approximately synchronous with the latest occurrences of Cyrtocapsella japonica and Cannartus laticonus. The zone includes the latest occurrence of Cannartus (?) petterssoni and the earliest appearance of Acrobotrys tritubus. The top of the zone is coincident with the base of the Ommatartus penultimus Zone.

\section{Ommatartus penultimus Zone:}

The base is defined by the earliest evolutionary appearance of Ommatartus penultimus, which is approximately synchronous with the latest occurrence of Ommatartus antepenultimus. The top of the zone is coincident with the base of the Stichocorys peregrina Zone. 
Stichocorys peregrina Zone:

Base is defined by the earliest appearance of Stichocorys peregrina, which is approximately synchronous with the latest occurrences of Acrobotrys tritubus and Stichocorys delmontensis. The top of the zone is coincident with the base of the Spongaster pentas Zone.

\section{Spongaster pentas Zone:}

The base is defined by the earliest appearance of Pterocanium prismatium, which is approximately synchronous with the latest occurrence of Ommatartus hughesi. The zone includes a little more than the total range of Spongaster pentas, and the latest occurrence of Ommatartus penultimus. The top of the zone is coincident with the base of the Pterocanium prismatium Zone.

\section{Pterocanium prismatium Zone:}

Base is defined by the latest occurrence of Stichocorys peregrina. The top of the zone is defined by the latest occurrence of Pterocanium prismatium.

\section{CORRELATION OF MICROFOSSIL ZONATIONS}

In order that age assignments based on radiolarians can be compared with assignments based on other microfossil groups, it is necessary to attempt an interrelation of the radiolarian zonation with those for the foraminifera and calcareous nannoplankton. The result of such an attempt is given in Figure 4.

The most reliable basis for correlation of the various zonations would be the investigation of the three types of microfossils found together in samples from long, continuous sequences. An opportunity for this may be provided as the Deep-Sea Drilling Program continues, but at present the attempt must be based on less satisfactory information. The footnotes to Figures 1, 2 and 3 provide direct linkages between the radiolarian zonation and foraminiferal and/or calcareous nannoplankton zonations. These linkages are indicated by the absences of parentheses in Figure 4. Parentheses are used in Figure 4 to distinguish correlations based, not on observation of more than one microfossil group in the same sample, but on published correlations such as those by Bolli (1966, Table 3), Bramlette and Wilcoxon (1967, Table 2) and Blow (1969, Figures 15 and 16). Except for the Eocene, where information is too sparse, hachured areas are used to indicate, approximately, the degree of uncertainty in the correlation of the limits of calcareous microfossil zones with the limits of the radiolarian zones. These are broad because the presentation here is a conservative interpretation of the information given in Figures 1,2 and 3 and the footnotes thereto.

\section{CENOZOIC RADIOLARIA IN THE DRILL-CORES}

Tables 1 through 4 show the occurrences of radiolarians in Cenozoic samples from Leg 4. The letters A, C, F and $\mathrm{R}$ indicate that a species is abundant, common, few or rare in relation to the total radiolarian assemblage in a sample, and ( + ) is used to indicate isolated occurrences of one or two specimens. Time has not permitted an exhaustive search for all species in all samples; and, therefore, a (-) sign is used to indicate the absence of a species from a sample in which it was searched for.

Site $29\left(14^{\circ} 47.15^{\prime} \mathrm{N}, 69^{\circ} 19.38^{\prime} \mathrm{W}\right.$; water depth 4247 meters)

Well preserved radiolarians occur in all samples from about 125 meters to about 230 meters below the sea floor. This material forms the basis for proposing the following sequence of radiolarian zones, from the top downward, which apparently span approximately all of the Middle Eocene - Podocyrtis chalara Zone, Podocyrtis mitra Zone, Podocyrtis ampla Zone, Thyrsocyrtis triacantha Zone and Theocampe mongolfieri Zone. Species occurring at this site are shown in Table 1. As is the case with all assemblages described in this paper, the tabulation includes only a fraction of the total number of species in the material.

Sites $27\left(15^{\circ} 51.39^{\prime} \mathrm{N}, 56^{\circ} 52.76^{\prime} \mathrm{W}\right.$; water depth 5251 meters $)$ and $28\left(20^{\circ} 35.19^{\prime} \mathrm{N}, 65^{\circ} 37.33^{\prime} \mathrm{W}\right.$; water depth 5521 meters)

Poorly preserved radiolarians occur from about 455 meters to about 475 meters below the sea floor at Site 27 , and ones in a rather better state of preservation occur from about 170 meters to about 280 meters below the sea floor at Site 28. Species occurring at these sites are shown in Table 2. The assemblages in Core 6 of Site 27 appear to be of an age very near the Eocene-Oligocene boundary, while Core 7 of Site 27 and the upper samples from Site 28 are in the Podocyrtis mitra Zone (and probably the upper part of this zone).

Site $31\left(14^{\circ} 56.60^{\prime} \mathrm{N}, 72^{\circ} 01.63^{\prime} \mathrm{W}\right.$; water depth 3369 meters)

At this site, rather well preserved radiolarians occur from about 215 meters to about 280 meters below the sea floor. The forms occurring in this interval are shown in Table 3. The samples from Core 9 and the top of Core 10 appear to belong in the Calocycletta virginis Zone, while those from the remainder of Core 10 apparently belong in the Lychnocanium bipes Zone. The only serious inconsistency in this interpretation is the presence (in the lower samples from Core 10) of Dorcadospyris forcipata, which is not known to occur below the Calocycletta virginis Zone in the Pacific. It may be that the form here identified as $D$. forcipata is not really the same as the Pacific 
TABLE 1

Radiolarians at Site 29

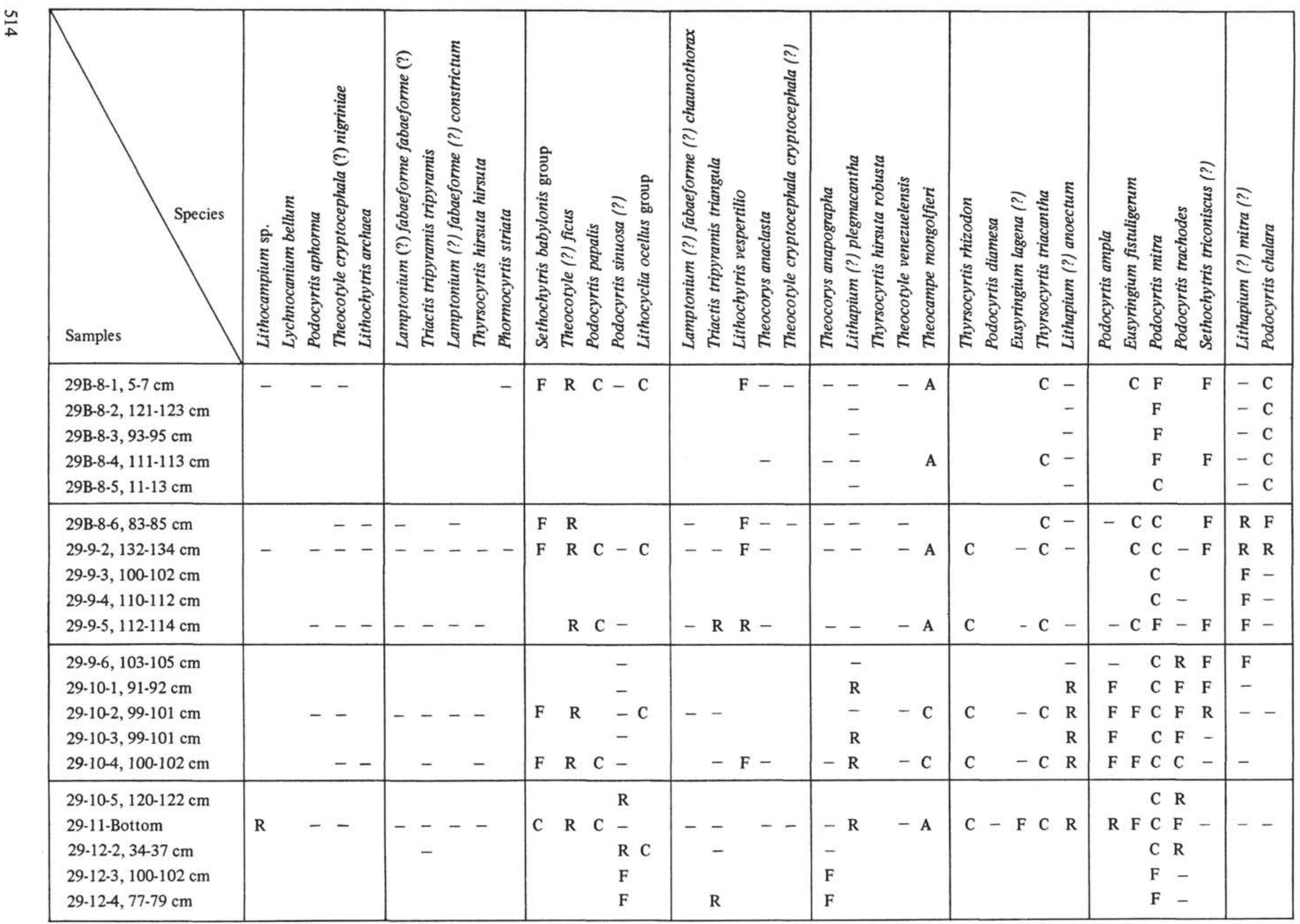


TABLE 1 - Continued

\begin{tabular}{|c|c|c|c|c|c|c|c|c|c|c|c|c|}
\hline $\begin{array}{l}29-12-5,108-110 \mathrm{~cm} \\
29-12-6,103-105 \mathrm{~cm} \\
29-13-\text { Bottom } \\
29-14-1,50-52 \mathrm{~cm} \\
29-14-2,117-119 \mathrm{~cm}\end{array}$ & $\begin{array}{l}--- \\
---\end{array}$ & $\begin{array}{l}- \\
-R\end{array}$ & $\begin{array}{lrrr}C & R & C & F \\
& & F \\
C & R & C & C \\
& & F \\
& & F\end{array}$ & $\begin{array}{l}-\mathrm{R}-- \\
-\quad--\end{array}$ & & $\mathrm{F}$ & $\begin{array}{l}-A \\
-A\end{array}$ & $\begin{array}{l}C-F \\
C-F\end{array}$ & F & $\begin{array}{l}\text { C R } \\
\text { C R }\end{array}$ & $\begin{array}{ll}\mathrm{F} & \mathrm{R} F-- \\
& \mathrm{R} F- \\
\mathrm{F} & \mathrm{R}--- \\
& \mathrm{R}- \\
\mathrm{R}-\end{array}$ & $\begin{array}{l}- \\
- \\
-\end{array}$ \\
\hline $\begin{array}{l}29-14-3,118-120 \mathrm{~cm} \\
29-14-4,102-104 \mathrm{~cm} \\
29-14-5,113-114 \mathrm{~cm} \\
29-14-6,135-137 \mathrm{~cm} \\
29-15-1,11-13 \mathrm{~cm}\end{array}$ & $\begin{array}{l}-- \\
---\end{array}$ & $\begin{array}{c}-- \\
---\end{array}$ & $\begin{array}{l}\text { C R C F C } \\
\text { F R C F }\end{array}$ & $\begin{array}{r}\mathrm{R}-- \\
\mathrm{R} \\
-\quad \mathrm{R} R--\end{array}$ & F $R$ & $\begin{array}{l}\mathrm{R} \\
\mathrm{R}-\mathrm{T} \\
\mathrm{R}\end{array}$ & $\begin{array}{l}-A \\
- \\
- \\
- \\
\end{array}$ & 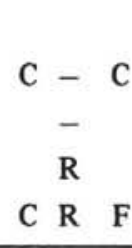 & C C & $\begin{array}{l}\mathrm{C} R \\
\mathrm{C} \mathrm{R}\end{array}$ & $\begin{array}{l}\mathrm{R} \\
\mathrm{R} \mathrm{R}-\quad- \\
\mathrm{R}- \\
\mathrm{R}- \\
\mathrm{R}--\quad-\end{array}$ & $\begin{array}{l}- \\
- \\
-\quad-\end{array}$ \\
\hline $\begin{array}{l}29-15-2,12-14 \mathrm{~cm} \\
29-15-3,13-15 \mathrm{~cm} \\
29-15-4,86-87 \mathrm{~cm} \\
29-15-5,90-92 \mathrm{~cm} \\
29-15-6,83-85 \mathrm{~cm}\end{array}$ & - & $\begin{array}{l}\mathbf{R} \\
- \\
- \\
- \\
\mathbf{R}\end{array}$ & F R F F & $\begin{array}{l}\mathrm{R} \\
\mathrm{R} \\
\mathrm{R} \\
-\mathrm{R}--\end{array}$ & F F & $\begin{array}{l}- \\
- \\
- \\
-\end{array}$ & $\begin{array}{l}- \\
- \\
- \\
-F C\end{array}$ & $\begin{array}{rrr} & R \\
& R \\
& F \\
\text { F } & R & F\end{array}$ & $\begin{array}{cc}\mathrm{c} \\
\mathrm{c} \\
\mathrm{c} \\
\mathrm{c} \\
\mathrm{c}\end{array}$ & $\begin{array}{l}\mathrm{C} \\
\mathrm{C} R \\
\mathrm{C} \\
\mathrm{C} R \\
\mathrm{C}\end{array}$ & $\begin{array}{l}-- \\
-- \\
---\end{array}$ & - \\
\hline $\begin{array}{l}29-16-1,116-118 \mathrm{~cm} \\
29-16-2,90-92 \mathrm{~cm} \\
29-16-3,86-88 \mathrm{~cm} \\
29-16-4,80-82 \mathrm{~cm} \\
29-16-5,84-86 \mathrm{~cm}\end{array}$ & $\mathrm{R}^{\mathrm{R}}-$ & $\begin{array}{c}- \\
---R \\
- \\
\text { R } \\
--\quad \text { R R }\end{array}$ & $\begin{array}{l}\text { F R F F C } \\
\text { F R F F }\end{array}$ & 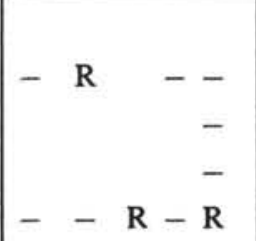 & $\begin{array}{ll}\mathrm{F} & \mathrm{F} \\
& \mathrm{F} \\
& \mathrm{F} \\
\mathrm{R} & \mathrm{R}\end{array}$ & $\begin{array}{ll}F & R \\
F & R \\
F & R \\
R & -\end{array}$ & $\begin{array}{l}- \\
\text { R F C } \\
\text { R } \\
\text { R } \\
- \text { F C }\end{array}$ & $\begin{array}{ll}\text { F F } & R \\
\text { C F } & F\end{array}$ & $\begin{array}{ll} & \mathrm{C} \\
\mathrm{R} & \mathrm{C} \\
\mathrm{C} & \mathrm{C}\end{array}$ & 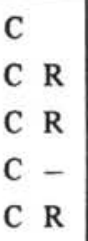 & - & $\begin{array}{ll}- & - \\
- & \\
- & \\
& -\end{array}$ \\
\hline
\end{tabular}


TABLE 1 - Continued

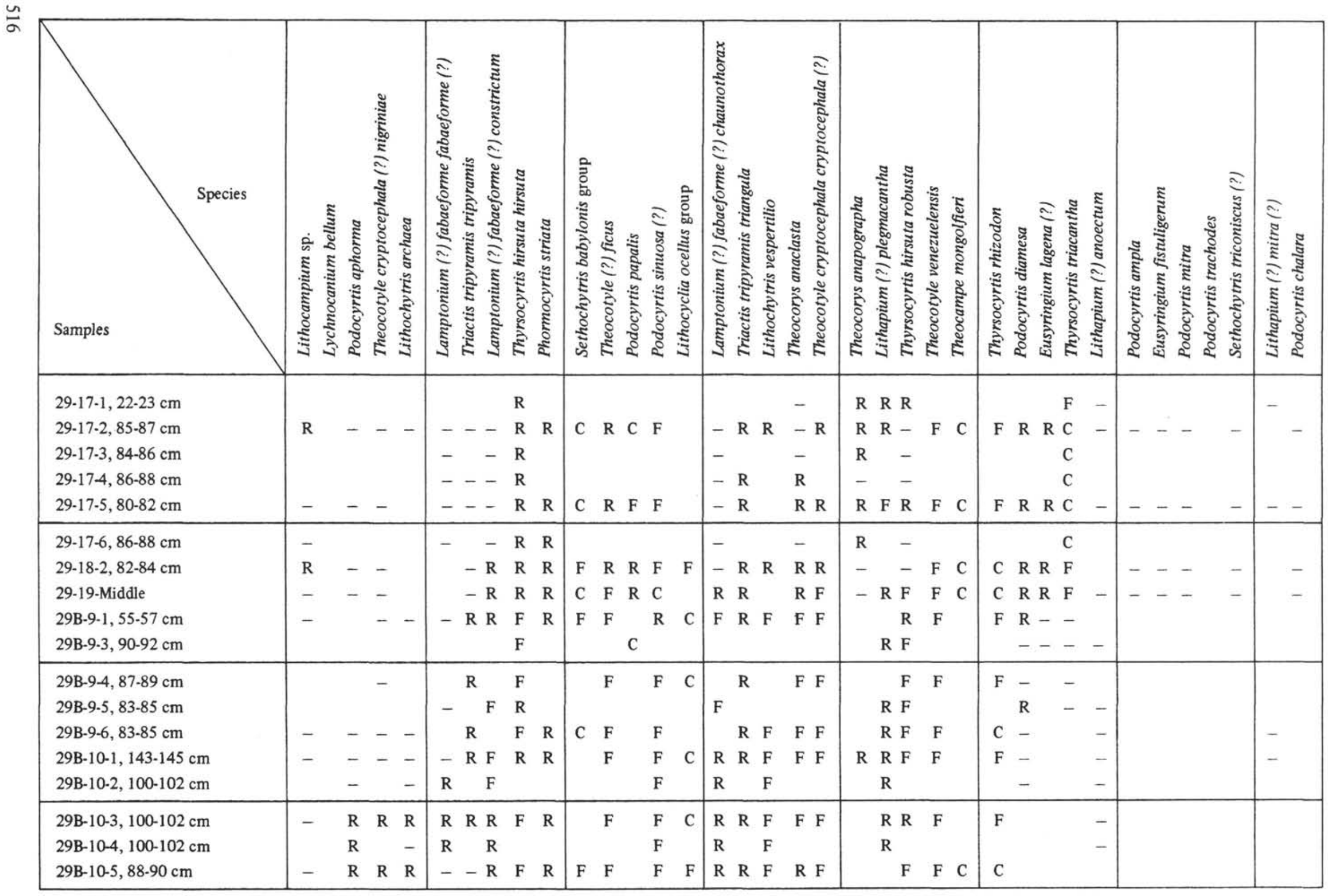


TABLE 2

Radiolarians at Sites 27 and 28

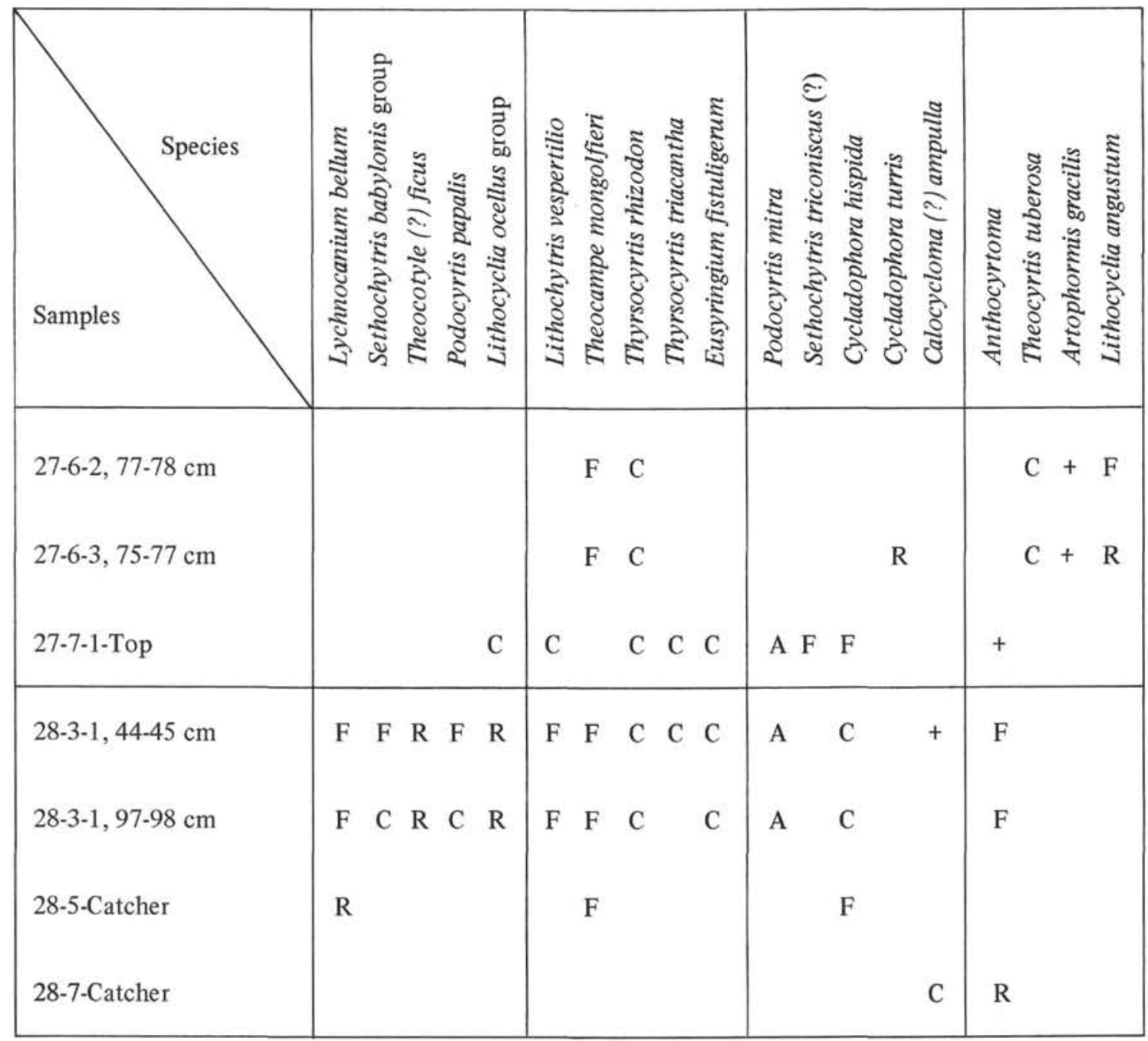


TABLE 3

Radiolarians at Site 31

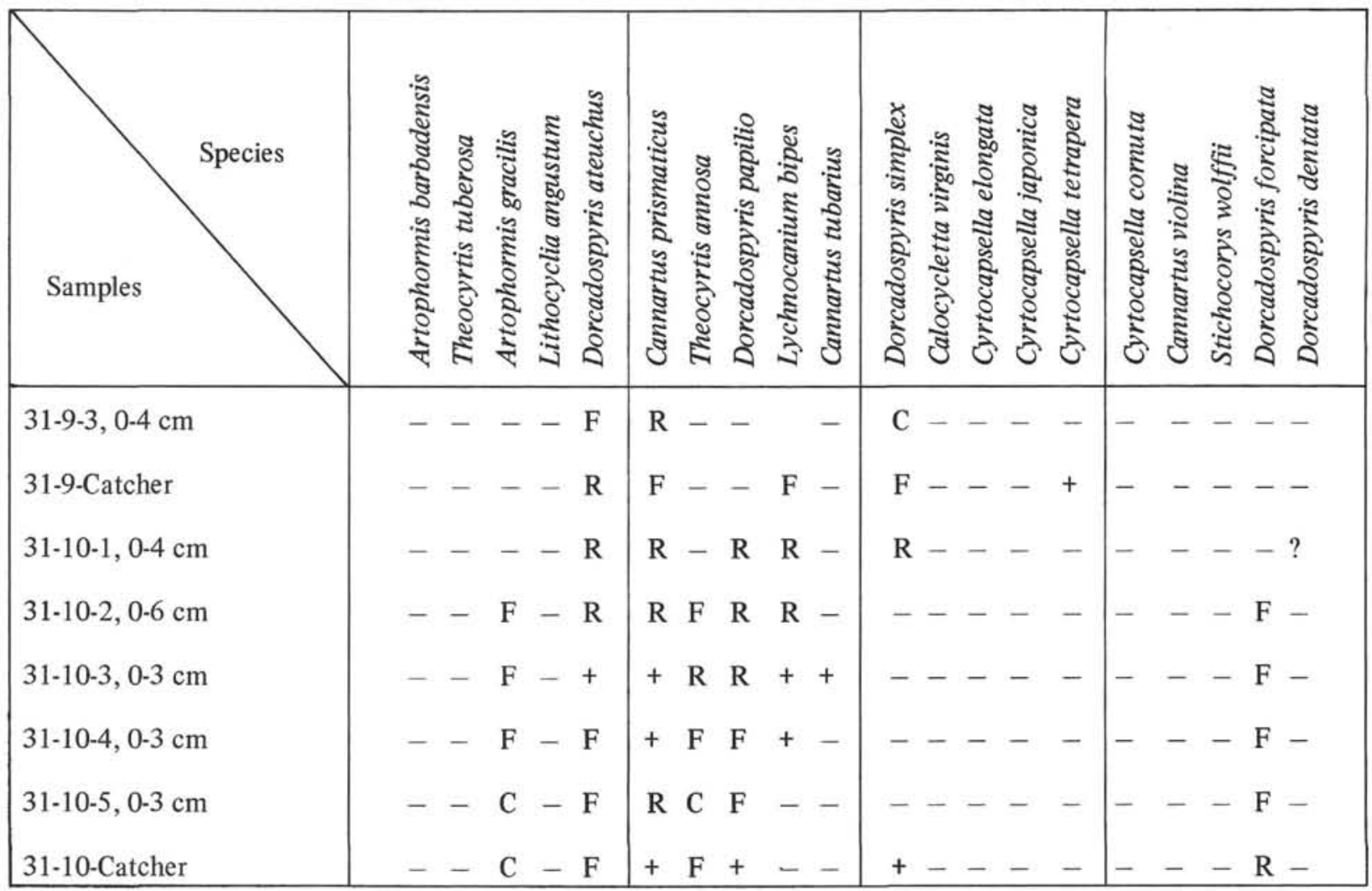

form, but instead shows only a superficial similarity. Although typical Calocycletta virginis is not present in this section, the upper samples contain a common form (Plate 14, Figure 11) which is similar except for the feet being wide and shovel-shaped rather than narrowly lamellar. This form occurs also in a Pacific assemblage from the lower part of the Calocycletta virginis Zone (CHUB 15, 78 to 82 centimeters).

Site $30\left(12^{\circ} 52.92^{\prime} \mathrm{N}, 63^{\circ} 23.00^{\prime} \mathrm{W}\right.$; water depth 1218 meters)

Radiolarians occur at various levels between about 380 meters and about 405 meters below the sea floor, varying in abundance and state of preservation from sample to sample. Table 4 shows occurrences in the well preserved assemblages. The samples from 30-10-3 to $30-12-2$ are assignable approximately to the Cannartus petterssoni Zone; the specimens of Ommatartus antepenultimus are early forms with scarcely developed polar caps. The samples from 30-12-4 to 30-13-2 may belong to the Cannartus laticonus Zone (if the few specimens of Calocycletta virginis and Dorcadospyris alata are reworked, which seems not improbable) or to the Dorcadospyris alata Zone.

\section{SYSTEMATIC SECTION (CENOZOIC FORMS)}

In this section, an attempt is made to classify the species here into natural genera which will be conformable with the revised family-level classification recently proposed (Riedel, 1967b and in press, a). With the abandonment of the geometrical classification of Haeckel, the earlier definitions of genera are no longer applicable, and emphasis is therefore placed on the relationships of species with the type species of established genera. The result is a genus-level classification which is in many places uncertain, and not yet nearly as comprehensive as Haeckel's, but which offers the possibility of being improved and expanded to reflect the true relationships of all Cenozoic polycystine radiolarians.

Type and figured specimens will be deposited in the U. S. National Museum, Washington, D. C. 
TABLE 4

Radiolarians at Site 30

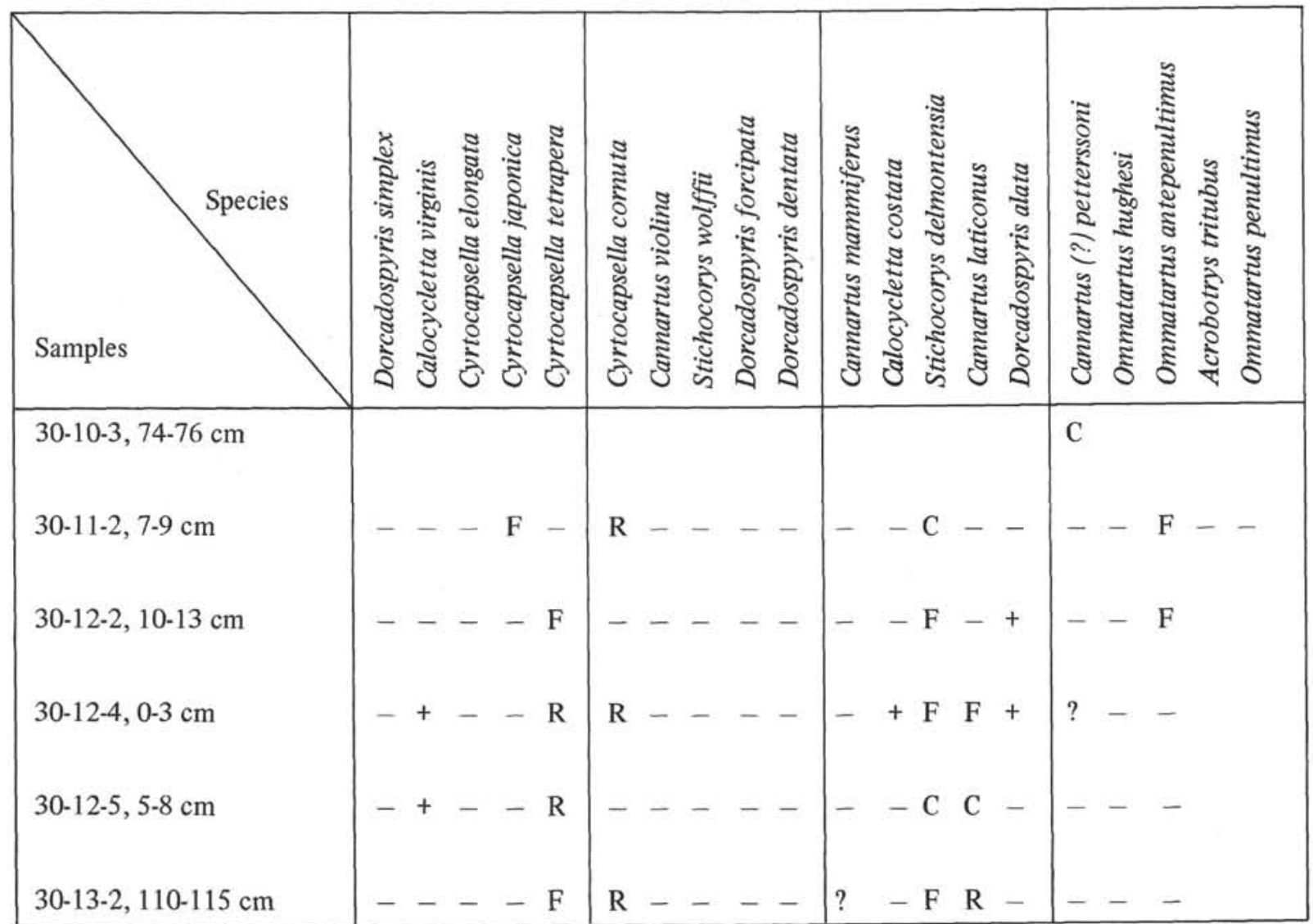

Dimensions of the skeletons are based on at least 25 specimens, from throughout the range of the species, unless otherwise indicated.

Two distinctive Eocene species occurring at Site 29, which are illustrated (Plate 4, Figure 1; Plate 10, Figure 6) but which time did not permit us to treat systematically, are Spongatractus pachystylus (Ehrenberg, 1873 , p. 256 ; 1875 , Plate 26, Figure 3; Haeckel, 1887 , p. 350) and Dictyophimus craticula (Ehrenberg, 1873, p. 223; 1875, Plate 5, Figures 4 and 5).

In view of the fact that the presence of a long axial rod has in the past been used as a distinguishing character for some genera, it is interesting to note that a long axial rod, branched distally, is present in some specimens of many of the larger cyrtoids in the assemblages from Site 29. Such an axial rod extends to the central or the distal part of the thorax in at least some speci- mens of Thyrsocyrtis hirsuta robusta, Podocyrtis papalis, $P$. aphorma and $P$. sinuosa, and into the abdominal cavity in at least some specimens of Theocotyle cryptocephala cryptocephala (?), Theocotyle venezuelensis, Theocotyle (?) ficus, Thyrsocyrtis rhizodon and Theocorys anaclasta. Thus, it occurs in several different lineages, and it does not appear to have taxonomic significance at the generic level.

Order POLYCYSTINA Ehrenberg

Polycystina Ehrenberg, 1838, emend. Riedel, 1967b, p. 291.

Suborder SPUMELLARIA Ehrenberg, 1875

Family ACTINOMMIDAE Haeckel

Actinommidae Haeckel, 1862, emend. Riedel, 1967b, p. 294. 


\section{Genus Lithapium Haeckel}

Lithapium Haeckel, 1887, p. 303. Type species (designated by Campbell, 1954, p. 69) Lithapium pyriforme Haeckel (1887, p. 303, Plate 14, Figure 9).

In the absence of any clear indication of the evolutionary development of the following two spherical to ellipsoidal forms, these species could be assigned on the basis of their general morphology to the genera Lithapium Haeckel 1887, Dorysphaera Hinde 1890 or Monostylus Cayeux 1897. Their doubtful assignment here to Lithapium is arbitrary, and does not imply any close relationship to the type species of that genus.

Lithapium (?) plegmacantha, new species (Plate 4, Figures 2 and 3):

Eucyrtidium ampullus [Ehrenberg] (?), Bury, 1862, Plate 12, Figure 1. [non] Eucyrtidium ampulla Ehrenberg, 1854, Plate 36, Figure 15.

Shell approximately spherical, but in one place drawn out as an acute, latticed cone which is surrounded by a bladed or conical spine. Pores subcircular to circular, and shell surface rough or thorny. Some specimens have several long three-bladed spines distributed over the surface with no regular arrangement. Length (excluding spine) 140 to $220 \mu$, breadth 115 to $180 \mu$.

Remarks: The relationships of this species are not known, but there is at least a superficial similarity to the much smaller pyriform medullary shells of some stylosphaerids.

Lithapium (?) anoectum, new species (Plate 4, Figures 4 and 5):

Similar to Lithapium (?) plegmacantha, but generally smaller, tending to be ellipsoidal, with rougher surface, no long auxiliary spines, and commonly with a short open tube with irregular termination at the end opposite the conical protuberance. Length (without spine) 125 to $180 \mu$, breadth 85 to $125 \mu$.

Lithapium (?) mitra (Ehrenberg) (?) (Plate 4, Figures 6 and 7):

[?] Cornutella mitra Ehrenberg, 1873, p. 221; 1875, Plate 2, Figure 8. [?] Cornutella circularis Ehrenberg, 1873, p. 221; 1875, Plate 2, Figure 4. [?] Podocyrtis (?) [sp.] Bury, 1862, Plate 9, Figure 4.

An acute cone with subcircular to polygonal pores increasing in size from the apex, with short apical horn and thorny surface. In most complete specimens, the shell is somewhat contracted distally, and terminates in an irregular number of spines of variable length. Total length 155 to $430 \mu$, maximum breadth 115 to $235 \mu$. Remarks: Although this species differs in its general form from Lithapium (?) anoectum, it seems clearly related to it because of the similar structure of wall and apex, and because it immediately succeeds it in the core. The transition takes place very rapidly, between 67 centimeters and 54 centimeters in 29-10-1 (an interval in which there is no evidence of an hiatus). It differs from the superficially similar sethophormids associated with it in that they have a less acute apex and, of course, collar pores.

The species assignment of this form is uncertain because of the inadequacy of Ehrenberg's illustrations and descriptions of Cornutella mitra and $C$. circularis.

In the latest occurrences of the species (e.g. in the Oceanic Formation of Barbados) the skeletons tend to become less thorny, more acutely conical, and with smaller pores-some of them to such an extent that it may be appropriate to separate them as a distinct species.

\section{Genus Cannartus Haeckel}

Cannartus Haeckel, 1881, p. 462. Type species (indicated by Campbell, 1954 , p. 74) Cannartus violina Haeckel (1887, p. 358, Plate 39, Figure 10).

Cannartus Haeckel, emend.; Riedel, in press, a.

Cannartus prismaticus (Haeckel) (Plate 15, Figure 1): Pipettella prismatica Haeckel, 1887, p. 305, Plate 39, Figure 6; Riedel, 1959, p. 287, Plate 1, Figure 1.

Cannartus tubarius (Haeckel) (Plate 15, Figure 2): Pipettaria tubaria Haeckel, 1887, p. 339, Plate 39, Figure 15; Riedel, 1959, p. 289, Plate 1, Figure 2.

Cannartus violina Haeckel:

Cannartus violina Haeckel, 1887 , p. 358 , Plate 39, Figure 10; Riedel, 1959, p. 290, Plate 1, Figure 3.

Cannartus mammiferus (Haeckel) (Plate 14, Figure 1): Cannartidium mammiferum Haeckel, 1887 , p. 375 , Plate 39, Figure 16. Cannartus mammiferus (Haeckel), Riedel, 1959, p. 291, Plate 1, Figure 4.

Cannartus laticonus Riedel (Plate 14, Figure 2): Cannartus laticonus Riedel, 1959, p. 291, Plate 1, Figure 5 .

Cannartus (?) petterssoni, new species (Plate 14, Figure 3):

Cannartus petterssoni, manuscript name proposed conditionally in Riedel and Funnell, 1964, p. 310.

Cortical shell rather thick-walled, approximately cylindrical (sometimes bulged at the equator), with pronounced protuberances surrounding each end of the cortical shell. Pores of the cortical shell circular or subcircular, smaller near the equator. Two medullary shells, of which the outer is commonly spherical, sometimes lenticular. Very broad spongy columns (in some specimens divided into narrow parallel zones) are 
separated from the cortical shell by a narrow clearer zone: the distal margin of this clearer zone is commonly at the end of the protuberances.

Length of spongy columns 25 to $100 \mu$ (commonly about $50 \mu$ ); their median breadth 50 to $85 \mu$. Length of cortical shell 80 to $100 \mu$; its maximum breadth (including protuberances) 75 to $95 \mu$. Breadth of outer medullary shell is 25 to $40 \mu$. (Measurements based on specimens from PROA 96P, 227 to 230 centimeters and SDSE 87,799 to 800 centimeters.)

Remarks: Although the spongy columns of some specimens show parallel zones, these are not distinct caps as in Ommatartus hughesi.

\section{Genus Ommatartus Haeckel}

Ommatartus Haeckel, 1881 , p. 463 . Type species (indicated by Campbell, 1954, p. 76) Ommatartus amphicanna Haeckel (1887, p. 396). Ommatartus Haeckel, emend.; Riedel, in press, a.

This species is named in honor of the late Prof. Hans Pettersson, who helped make possible the first stratigraphic application of Cenozoic radiolarians, in cores collected by the Swedish Deep-Sea Expedition.

Ommatartus antepenultimus, new species (Plate 14, Figure 4):

Panarium antepenultimum, manuscript name proposed conditionally in Riedel and Funnell, 1964, p. 311.

Cortical and medullary shells similar to those of Cannartus laticonus and Ommatartus penultimus. $C$. laticonus has no polar caps (the distal boundary of the narrow clearer zone between the cortical twinshell and spongy column is parallel to the distal wall of the cortical shell, as in Plate 14, Figure 2), while O. penultimus s.s. has caps at least as well developed as its holotype (Riedel, 1957a, Plate 1, Figure 1). $O$. antepenultimus includes all forms in which the development of the caps (and spongy columns) is intermediate between these two.

Length of spongy columns 20 to $90 \mu$; their median breadth 20 to $55 \mu$. Height of polar caps 15 to $35 \mu$. Length of cortal shell 90 to $115 \mu$; its maximum breadth (including protuberances) 75 to $115 \mu$. Breadth of outer medullary shell 25 to $40 \mu$. (Measurements based on specimens from AMPH 6P, 15 to 17 centimeters; SDSE 87, 399-400 centimeters; and PROA 102P, 490 to 492 centimeters.

Ommatartus hughesi (Campbell and Clark):

Ommatocampe hughesi Campbell and Clark, 1944a, p. 23, Plate 3, Figure 12.
Ommatartus penultimus (Riedel), sensu stricto:

Panarium penultimum Riedel, 1957a, p. 76, Plate 1, Figure 1; Riedel and Funnell, 1964, p. 311.

\section{Family PH ACODISCID AE Haeckel, 1881}

\section{Genus Triactis Haeckel}

Triactis Haeckel, 1881, p. 457.

Triactiscus Haeckel, 1887, p. 432. Type species (designated by Strelkov and Lipman, 1959, p. 433) Triactiscus tripyramis Haeckel (1887, p. 432, Plate 33, Figure 6).

Phacotriactis Sutton, 1896a, p. 61. Type species (by monotypy) Phacotriactis triangula Sutton (1896a, p. 61, Figure 3).

Triactiscus appears to be a junior objective synonym of Triactis under the provisions of Article 33 of the International Code of Zoological Nomenclature (and was so treated by Campbell, 1954, p. 81). Triactoma Rüst, however, is not such a synonym-it was evidently erected by Rüst to include forms with a spherical lattice-shell. The type species of Triactiscus may be $T$. tripyramis as indicated above, but a case might also be made for its being (by absolute tautonymy) Haliomma triactis Ehrenberg (1873, p. 236; 1875, Plate 28, Figure 4) which Haeckel (1887, p. 432) renamed Triactiscus tripodiscus. Whichever of the two possibilities is upheld does not affect the generic assignment of the species described below, because both candidates for type species of Triactiscus are evidently very closely related.

Triactis tripyramis tripyramis Haeckel (Plate 4, Figure 8):

Triactiscus tripyramis Haeckel, 1887, p. 432, Plate 33, Figure 6.

Similar in structure and dimensions to Triactis tripyramis triangula, but phacoid cortical shell circular or more circular than triangular. Although the evidence is inconclusive because of the rarity of the species, it appears that this subspecies may have evolved into Triactis tripyramis triangula.

This species was originally described from a sediment sample (Challenger Station 272) in which most of the radiolarians are Quaternary but which contains rare admixed Eocene forms including Theocotyle cryptocephala (?) nigriniae, Thyrsocyrtis hirsuta hirsuta and Podocyrtis papalis.

Triactis tripyramis triangula (Sutton) (Plate 4, Figures 9 and 10):

Phacotriactis triangula Sutton, 1896a, p. 61.

Phacoid cortical shell equilaterally triangular, usually thick-walled, with very small circular pores. From each corner of the shell projects a stout three-bladed spine, of about the same length as the radius of the 
shell. Medullary shell apparently double, the outer one with a diameter approximately one-third of the diameter of the cortical shell.

Length from one point of the cortical shell (excluding the spine) to the middle of the opposite side 115 to $150 \mu$.

Remarks: The sides of the triangular cortical shell are straight, concave or convex, and specimens are assigned to this subspecies rather than to the other if the shell is judged to be more triangular than circular.

\section{Family COCCODISCID AE Haeckel, 1862}

\section{Genus Lithocyclia Ehrenberg}

Lithocyclia Ehrenberg, 1847a, chart to p. 385. Type species (by monotypy) Lithocyclia ocellus Ehrenberg (1854, Plate 36 , Figure $30 ; 1873$, p. $240 ; 1875$, Plate 29, Figure 3).

Although it is not yet possible to define satisfactorily the limits of this genus, it seems advisable to include in it a wide variety of forms with and without radial spines, and with and without radiating spongy arms. Thus, it may perhaps be desirable to synonymize the following genus-group taxa with Lithocyclia:

Astractinium Haeckel, 1887, p. 476. Type species (designated by Campbell, 1954, p. 83) Astromma aristotelis Ehrenberg (1847b, p. 55, Figure 10; 1854, Plate 36 , Figure $32 ; 1873$, p. 217; 1875, Plate 30, Figures 3 and 4).

Astractura Haeckel, 1881, p. 459. Type species (indicated by Campbell, 1954, p. 82) Astractura ordinata Haeckel (1887, p. 476; Bury, 1862, Plate 14, Figure 3).

Astrococcura Sutton, 1896b, p. 138. Type species (by monotypy) Astrococcura concinna Sutton (1896b, p. 138).

Astrocyclia Haeckel, 1881, p. 458. Type species (indicated by Campbell, 1954, p. 82) Astrocyclia solaster Haeckel (1887, p. 466, Plate 36, Figure 7).

Hymenactinium Haeckel, 1887, p. 475. Type species (designated by Campbell, 1954, p. 83) Hymenactura copernici Haeckel (1887, p. 475, Plate 38, Figure 9).

Hymenactura Haeckel, 1881, p. 459. Type species (indicated by Campbell, 1954, p. 83) Hymenactura archimedis Haeckel (1887, p. 473, Plate 38, Figure 8).

Hymeniastrum Ehrenberg, 1847a, chart to p. 385. Type species (by monotypy) Hymeniastrum pythagorae Ehrenberg (1854, Plate 36, Figure $31 ; 1873$, p. 237; 1875 , Plate 30, Figure 5).

Pentactura Haeckel, 1881, p. 459. Type species (indicated by Campbell, 1954, p. 83) Astromma pentactis Ehrenberg (1873, p. $217 ; 1875$, Plate 30 , Figure 1).
Lithocyclia ocellus group (Plate 5, Figures 1 and 2): Medullary shell double. Phacoid cortical shell with circular to subcircular pores, 12 to $18 \mu$ on a diameter, covered in some specimens by a thin spongy layer. Cortical shell surrounded by a continuous spongy zone which, in late specimens especially, is usually concentrically zoned, the innermost zone commonly being the widest and most distinct. Spines of variable number (sometimes none), bladed, acute, originate within the spongy zone, or at the periphery of the cortical shell, or occasionally at the outer medullary shell.

Diameter of outer medullary shell 35 to $50 \mu$, of cortical shell 85 to $140 \mu$, of outer spongy zone 165 to $325 \mu$.

Remarks: The species-group name is here applied to a variety of forms that seem not to be satisfactorily differentiated, including, for example, Lithocyclia ocellus Ehrenberg (1854, Plate 36, Figure 30; 1873, p. 240$),$ L. stella Ehrenberg $(1873$, p. $240 ; 1875$, Plate 29 , Figure 2), and a number of species described in the genera Coccocyclia Haeckel and Astrocyclia Haeckel.

\section{Lithocyclia aristotelis group:}

This species-group name is used for a number of forms with skeletons similar to those of the $L$. ocellus group, but with separated spongy arms rather than a continuous spongy zone around the phacoid shell. In this group are included forms with three or four (or more?) arms, with or without terminal spines, and with or without a patagium:

Astromma pythagorae Ehrenberg, 1872a, p. 301; 1873, p. $217 ; 1875$, Plate 30 , Figure 2.

Astromma aristotelis Ehrenberg, 1847b, p. 55, Figure $10 ; 1854$, Plate 36 , Figure $32 ; 1873$, p. $217 ; 1875$, Plate 30, Figures 3 and 4.

Hymeniastrum pythagorae Ehrenberg, 1854, Plate 36, Figure $31 ; 1873$, p. 237; 1875, Plate 30, Figure 5.

[?] Astromma pentactis Ehrenberg, 1873,p. 217; 1875, Plate 30, Figure 1.

Lithocyclia angustum (Riedel) (Plate 13, Figures 1 and 2):

Trigonactura angusta Riedel, 1959, p. 292, Plate 1, Figure 6.

Family SPONGODISCIDAE Haeckel

Spongodiscidae Haeckel, 1862, emend. Riedel, 1967b, p. 295.

\section{Genus Spongaster Ehrenberg}

Spongaster Ehrenberg, 1860, p. 833. Type species (by monotypy) Spongaster tetras Ehrenberg (1860, p. $833 ; 1861$, p. $301 ; 1872$ b, Plate 6 [3], Figure 8 ). 
Spongaster pentas, new species (Plate 15, Figure 3): Spongy disc usually pentagonal, occasionally hexagonal. Rays from center to marginal angles generally not markedly denser (but usually slightly thicker) than the spongy structure between them. Central area (one-half to one-third of disc diameter) more dense, or thicker, with concentric structure. Diameter 170 to $290 \mu$. (Measurements based on specimens from MSN 143P, 796 to 798 centimeters and LSDH 78P, 63 to 522 centimeters.)

This species is distinguished from $S$. tetras, to which it is apparently very closely related, by its pentagonal or hexagonal outline.

\section{Suborder NASSELLARIA Ehrenberg, 1875}

Family ACANTHODESMIIDAE Haeckel, 1862 Acanthodesmiidae Haeckel; Riedel, 1967b, p. 296. A series of forms which seem to illustrate the development of Giraffospyris didiceros (Ehrenberg) (Goll, 1969 , p. 332 , text-figure 2 , Plate 60 , Figures $5,6,7$ and 9) are illustrated from Site 29 (Plate 5, Figures 3,4 and 5), but not treated systematically.

\section{Genus Dorcadospyris Haeckel}

Dorcadospyris Haeckel, 1881, p. 441. Type species (indicated by Campbell, 1954, p. 112) Dorcadospyris dentata Haeckel (1887, p. 1040, Plate 85, Figure 6).

Dorcadospyris Haeckel, emend.; Goll, 1969, p. 335. If the evolutionary sequence proposed by Riedel (1959, p. 293, text-figure 3) and the relationships indicated by Goll (1969, text-figure 2) are correct, it would seem appropriate to assign the following species to this genus.

Dorcadospyris ateuchus (Ehrenberg) (Plate 15, Figure 4):

Ceratospyris ateuchus Ehrenberg, 1873, p. 218.

Cantharospyris ateuchus (Ehrenberg); Riedel, 1959, p. 294, Plate 22, Figures 3 and 4.

Dorcadospyris papilio (Riedel) (Plate 15, Figure 5): Hexaspyris papilio Riedel, 1959, p. 294, Plate 2, Figures 1 and 2.

Dorcadospyris simplex (Riedel) (Plate 15, Figure 6): Brachiospyris simplex Riedel, 1959, p. 293, Plate 1, Figure 10.

Dorcadospyris forcipata (Haeckel) (Plate 15, Figure 7): Dipospyris forcipata Haeckel, 1887, p. 1037, Plate 85, Figure 1.

Dipodospyris forcipata Haeckel; Riedel, 1957a, p. 79, Plate 1, Figure 3.
Dorcadospyris dentata Haeckel:

Dorcadospyris dentata Haeckel, 1887, p. 1040, Plate 85, Figure 6; Riedel 1957a, p. 79, Plate 1, Figure 4.

Dorcadospyris alata (Riedel) (Plate 14, Figure 5):

Brachiospyris alata Riedel, 1959, p. 293, Plate 1, Figures 11 and 12.

\section{Family THEOPERIDAE Haeckel}

Theoperidae Haeckel, 1881, emend. Riedel, 1967b, p. 296.

\section{Genus Lamptonium Haeckel}

Lamptonium Haeckel, 1887, p. 1378. Type species (designated by Campbell, 1954, p. 132) Cycladophora enneapleura Haeckel (1887, p. 1378).

Lamptonium (?) fabaeforme fabaeforme (Krasheninnikov) (?) (Plate 5, Figure 6):

[?] Cyrtolcalpis fabaeformis Krasheninnikov, 1960, p. 296, Plate 3, Figure 11.

Cephalis spherical, surrounded by the thick wall continuing upward from the thorax, bearing a conical or bladed horn of variable length. Thorax inflated-pyriform, with rough or thorny surface, and with circular or subcircular pores which are largest in the midregion. Abdomen short, narrow, subcylindrical or tapering, with irregularly scattered pores and no differentiated termination.

Length of cephalis plus the thorax 140 to $225 \mu$, maximum breadth 115 to $155 \mu$. Earlier forms tend to be narrower.

Remarks: The relationship, if any, to some other forms with inflated thorax that occur in this sequence (Plate 6, Figures 1 through 4) has not been determined. Also, its specific identification and generic relationship are very uncertain. In general form it resembles the Middle Eocene Cyrtocalpis fabaeformis Krasheninnikov, but it (and probably also Krasheninnikov's species) is certainly not related to the type species of Cyrtocalpis, which is a carpocaniid. The only genus-group taxon with a type species which might possibly be related to the species here described seems to be Lamptonium, and this is the uncertain basis for the generic assignment made here.

Lamptonium (?) fabaeforme (?) constrictum, new subspecies (Plate 5, Figure 7):

Generally similar to the nominate subspecies, but differing in that at the base of the narrow part of the thorax is a constriction which is, however, not accompanied by an internal septal ring. The horn is often long, and in some specimens, twisted spirally. 
Length of cephalis plus thorax 165 to $235 \mu$, maximum breadth 125 to $190 \mu$.

Lamptonium (?) fabaeforme (?) chaunothorax, new subspecies (Plate 5, Figures 8 and 9):

Similar to the nominate subspecies, but with larger thoracic pores.

Length of cephalis plus thorax 165 to $235 \mu$, maximum breadth 135 to $170 \mu$.

\section{Genus Anthocyrtoma Haeckel}

Anthocyrtoma Haeckel, 1887, p. 1268. Type species (designated by Frizzell and Middour, 1951, p. 29) Anthocyrtis serrulata Ehrenberg (1873, p. 217; 1875, Plate 6, Figure 7).

In the middle Eocene sediments at Site 29, and in the Eocene part of the Oceanic Formation of Barbados, occur two or more species of dicyrtids with inflated thorax and rather constricted mouth (Plate 6, Figures 2 through 4 ), which seem to be closely related to the type species of this genus. They may also be related to the species questionably assigned to Lamptonium, but because of the uncertainty of the relationship the two groups of species are assigned to different genera for the time being (though the apparently close relationship of the type species of Lamptonium and Anthocyrtoma suggest that these two genera might appropriately be synonymized).

The limits of the species comprising this group have not yet been determined, and therefore all are tabulated together as Anthocyrtoma spp. There seems to be some tendency for the larger form to have its mouth more constricted higher in the section, and for the smaller form to become more hispid upward.

Dimensions of the larger form: length (cephalis plus thorax) 205 to $265 \mu$, maximum breadth (excluding spines) 165 to $220 \mu$, and the dimensions of the smaller form: length 150 to $230 \mu$, maximum breadth 115 to $185 \mu$.

\section{Genus Calocycloma Haeckel}

Calocycloma Haeckel, 1887, p. 1384. Type species (designated by Campbell, 1954, p. 132) Calocyclas casta Haeckel (1887, p. 1384, Plate 73, Figure 10).

It is not yet possible to be confident in the assignment of species to this and related genera, because there appears to be some confusion in the literature regarding the number of segments. In forms resembling the type species, the proximal part of the inflated segment has much smaller pores than the distal part, and there is commonly a change in contour between the two parts. In the specimens that have been observed from the Oceanic Formation on Barbados and from Site 29 the authors have not found a segmental division separating these two parts of the inflated segment, and, therefore, it is doubtful whether it is appropriate to assign them to this genus.

Calocycloma (?) ampulla (Ehrenberg) (Plate 6, Figure 1):

Eucyrtidium ampulla Ehrenberg, 1854, Plate 36, Figure $15 ; 1873$, p. $225 ; 1875$, Plate 10 , Figures 11 and 12.

Cephalis hemispherical to subspherical, with a few small pores or pits, bearing a small conical horn. Collar stricture not strongly expressed externally. Thorax conical proximally and inflated distally, with constricted mouth surrounded by a distinct peristome. Pores of the conical part small, subcircular, in approximate longitudinal rows separated by ribs; those of the inflated part much larger, with thick intervening bars from the points of junction of which arise surface thorns or spines.

Total length (excluding horn) 140 to $185 \mu$, maximum breadth (excluding spines) 125 to $175 \mu$.

Remarks: In the lowest samples dealt with, some specimens of this species tend to have smaller pores and a shorter conical proximal part of the thorax than do later specimens. The relation between this species and that reported by Nigrini from Leg 2 as Calocyclas casta Haeckel has not yet been determined.

\section{Genus Theocotyle, new genus}

Type species: Theocotyle venezuelensis, new species.

This genus is erected to include the members of the lineage leading from Theocotyle cryptocephala (?) nigriniae to $T$. venezuelensis, inclusive, and perhaps to $T$. (?) ficus. Shells are three-segmented, terminated in a distinctly differentiated peristomial collar. The cephalis is hemispherical to subspherical (bearing an apical horn), the thorax campanulate, hemispherical or conical, and the abdomen (the largest segment) subcylindrical to inflated.

In the Haeckelian system, the species included in this genus might be included in the genus Theocorys or Theocorythium. However, Theocorys is used later in this paper for two species which seem to be not closely related to those described here, and the type species of Theocorythium is apparently a pterocoryid. At least the first three of the four forms described below clearly belong to a distinct lineage, which seems best treated under a new generic name.

The generic name is derived from the Greek "theos" (divine) and "kotyle" (small cup; feminine). 
Theocotyle cryptocephala cryptocephala (Ehrenberg) (?) (Plate 6, Figures 7 and 8):

[?] Eucyrtidium cryptocephalum Ehrenberg, 1873, p. 227; 1875, Plate 11, Figure 11.

Similar in structure to Theocotyle cryptocephala (?) nigriniae, but with thicker shell wall, more inflated abdomen, and abdominal pores consistently larger than those of the thorax.

Length (excluding horn) 140 to $170 \mu$, maximum breadth 110 to $135 \mu$.

Theocotyle cryptocephala (?) nigriniae, new subspecies (Plate 6, Figures 5 and 6):

Cephalis hemispherical, with small circular pores, bearing a conical horn of variable length. Thorax campanulate, almost as wide as the abdomen, with circular pores. Lumbar stricture distinct. Abdomen subcylindrical or slightly inflated, usually longer than thorax but commonly shorter in early specimens. Abdominal pores subcircular, as large to about twice as large as those of the thorax, commonly in longitudinal rows. Abdomen terminates in a thickened poreless rim which occasionally bears three or more short, pointed projections.

Length (excluding horn) 110 to $205 \mu$, maximum breadth 70 to $125 \mu$.

Remarks: This species was recorded as Theocorys sp. by Nigrini in her report on the radiolarians from Leg 2 of this expedition, and the specimens illustrated by her are considered to be more typical of the subspecies than those illustrated here. Therefore, we designate as holotype the specimen illustrated in her Plate 4, Figure 12.

Theocotyle venezuelensis, new species (Plate 6, Figures 9 and 10; Plate 7, Figures 1 and 2):

Cephalis subspherical, with few small pores, bearing a short conical horn. Collar and lumbar strictures distinct. Thorax hemispherical (tending to become conical in late specimens), with circular pores. Abdomen inflated, much wider than the mouth and the thorax, with large circular pores and terminating in a thickened rim. Surface of thorax and abdomen rough.

Length (excluding horn) 155 to $240 \mu$, maximum breadth 125 to $210 \mu$.

Remarks: This species is distinguished from late specimens of Theocotyle cryptocephala cryptocephala by its larger and more inflated abdomen, and from Theocotyle (?) ficus by its larger abdominal pores, generally thinner wall, and usually hemispherical thorax. However, some late specimens with relatively small, almost conical thorax might be confused with Theocotyle (?) ficus; later specimens are considerably larger than earlier ones, with the thorax relatively smaller.

Theocotyle (?) ficus (Ehrenberg) (Plate 7, Figures 3, 4 and 5):

Eucyrtidium ficus Ehrenberg, 1873, p. 228; 1875, Plate 11, Figure 19.

Cephalis subspherical, with small circular pores, merging in contour with the thorax, bearing a bladed or conical horn of variable length. Cephalis conical, with small circular pores. Lumbar stricture very slight or not expressed externally. Abdomen large, inflated (sometimes with straight sides), with circular pores arranged quincuncially in apparent longitudinal rows, and with a thickened rim around the somewhat constricted mouth. The entire shell is thick-walled.

Length (excluding horn) 155 to $240 \mu$, maximum breadth 140 to $225 \mu$.

Remarks: The distinction of this species from Theocotyle venezuelensis is discussed under that heading.

\section{Genus Thyrsocyrtis Ehrenberg}

Thyrsocyrtis Ehrenberg, 1847b, chart to p. 54. Type species (indicated by Campbell, 1954, p. 130) Thyrsocyrtis rhizodon Ehrenberg (1873, p. 262; 1875, Plate 12, Figure 1).

Podocyrtarium Haeckel, 1887, p. 1337. Type species (designated by Campbell, 1954, p. 130) Podocyrtis tripodiscus Haeckel (1887, p. 1338, Plate 72, Figure 4).

The five forms described below are assigned to the same genus as a matter of convenience, rather than from a conviction that they are closely related. Thyrsocyrtis triacantha (and subsequently $T$. tetracantha) may be descended from $T$. hirsuta, but it is not yet possible to demonstrate this. T. rhizodon may also have developed from $T$. hirsuta hirsuta, but it is equally possible that it developed from Theocotyle cryptocephala (?) nigriniae - this possibility derives some credence from the fact that occasional specimens of the latter form have three short projections from the poreless abdominal rim. Thyrsocyrtis bromia may have developed from $T$. rhizodon. It may eventually prove desirable to establish two subgenera to accommodate these separate lineages.

Thyrsocyrtis rhizodon Ehrenberg (Plate 7, Figures 6 and 7):

Thyrsocyrtis rhizodon Ehrenberg, 1873, p. 262;1875, Plate 12, Figure 1.

[?] Podocyrtis rhizodon Ehrenberg, 1873, p. 253; 1875, Plate 15, Figure 2.

[?] Thyrsocyrtis rhizopus Haeckel, 1887, p. 1351. 
Cephalis subspherical, with rather few small pores, bearing a conical horn which is usually short but occasionally up to half the length of the shell. Collar stricture, and usually the lumbar stricture, distinct. Thorax campanulate, with small subcircular pores. Abdomen barrel-shaped, wider and usually longer than the thorax, with pores commonly 2 to 3 times as large as those of the thorax. Surface of thorax and abdomen rough. Three short feet arise smoothly from the poreless abdominal rim, and are terminally truncate or bluntly pointed, sometimes with an outwardly direct ridge or indistinct thorn, or occasionally more complicatedly branched.

Length (excluding horn and feet) 125 to $180 \mu$, maximum breadth 85 to $125 \mu$.

Remarks: Later specimens tend to have a more robust wall than earlier ones, and consequently have the collar and lumbar strictures less pronounced or not at all expressed externally. Also, in later specimens, the feet are usually short and not branched terminally.

\section{Thyrsocyrtis bromia Ehrenberg:}

Thyrsocyrtis bromia Ehrenberg, 1873, p. 260; 1875, Plate 12, Figure 2.

Although no transitional forms have been found (perhaps because of too wide spacing of available samples), it seems probable that $T$. bromia arose from $T$. rhizodon, the latter persisting to occur together with the former.

Thyroscyrtis hirsuta hirsuta (Krasheninnikov) (Plate 7, Figures 8 and 9):

Podocyrtis hirsutus Krasheninnikov, 1960, p. 300, Plate 3, Figure 16.

Cephalis subspherical, poreless or with a few small pores, bearing a cylindrical or elongate conical horn which is extremely variable in length and thickness. Collar and lumbar strictures distinct. Thorax campanulate, somewhat inflated, with subcircular pores. Abdomen subcylindrical or slightly inflated, of approximately the same length and breadth is the thorax, with subcircular pores generally slightly larger than those of the thorax. Shell wall not very robust, of about the same thickness in thorax and abdomen, with rough surface. Three feet arise smoothly from poreless rim of abdomen, and are subcylindrical and tapered (often widest medially), slightly divergent, generally curved with convexity inward, often as long as the abdomen.

Length (excluding horn and feet) 120 to $195 \mu$, maximum breadth 80 to $140 \mu$.

Remarks: This form differs from Thyrsocyrtis rhizodon in having simply pointed feet. Earlier forms, considered more typical of this subspecies, have a more conical thorax and smoother shell surface.

Thyrsocyrtis hirsuta robusta, new subspecies (Plate 8, Figure 1):

Similar to Thyrsocyrtis hirsuta hirsuta but with usually more inflated thorax, larger pores, shell wall more robust and very rough or slightly thorny, and feet which are sometimes straight or curved with convexity outward, and sometimes ragged terminally.

Length (excluding horn and feet) 195 to $230 \mu$, maximum breadth 115 to $155 \mu$.

Remarks: This form differs from Thyrsocyrtis triacantha in having a larger thorax, and an abdominal wall structure not so pronouncedly different from that of the thorax.

Thyrsocyrtis triacantha (Ehrenberg) (Plate 8, Figures 2 and 3):

[?] Podocyrtis cothurnata Ehrenberg, 1854, Plate 36, Figure 21; 1873, p. 250; 1875, Plate 14, Figure 1.

[?] Podocyrtis schomburgkii Ehrenberg, 1847b, Figure $1 ; 1854$, Plate 36 , Figure $22 ; 1873$, p. $253 ; 1875$, Plate 14, Figure 7.

Podocyrtis princeps Ehrenberg, 1873, p. 252; 1875, Plate 13, Figure 1.

Podocyrtis radicata Ehrenberg, 1873, p. 253; 1875, Plate 13, Figure 5.

Podocyrtis triacantha Ehrenberg, 1873, p. 254; 1875, Plate 13, Figure 4.

Cephalis subspherical, poreless or with a few small pores, bearing a cylindrical or elongate-conical horn of variable length and thickness. Collar stricture distinct. Thorax considerably shorter than abdomen, broadly conical or slightly inflated, with small subcircular pores. Lumbar stricture slight. Abdomen is the broadest segment with thick wall, large subcircular pores, and poreless distal rim, occasionally with thorny surface. Three feet cylindrical, of variable length (often longer than abdomen), curved with convexity generally outward, with terminations simple or ragged, rarely forked.

Length (excluding horn and feet) 145 to $220 \mu$, breadth of abdomen 120 to $180 \mu$.

Remarks: This form is defined more broadly than earlier authors defined it and related species, but at present we find it difficult to separate species or subspecies within it. We have, however, excluded a larger form (Plate 8, Figure 4) with less robust, broader abdomen, relatively small abdominal pores, and generally three-bladed feet. 
Thyrsocyrtis tetracantha (Ehrenberg):

Podocyrtis tetracantha Ehrenberg, 1873, p. 254; 1875, Plate 13, Figure 2.

Podocyrtis aculeata Ehrenberg, 1873, p. 248; 1875, Plate 13, Figure 3.

Podocyrtis pentacantha Ehrenberg, 1873, p. 252;1875, Plate 17, Figure 1.

The earliest specimens of $T$. tetracantha have a less robust abdomen with no thickened termination, and commonly no well-developed feet. It seems likely that these early forms developed from $T$. triacantha by loss of the differentiated peristomial rim and the feet.

\section{Genus Eusyringium Haeckel}

Eusyringium Haeckel (1881, p. 437). Type species (designated by Frizzell and Middour, 1951, p. 35) Eusyringium conosiphon Haeckel (1887, p. 1496, Plate 78, Figure 10).

[?] Sethocapsa Haeckel (1881, p. 433). Type species (indicated by Strelkov and Lipman, 1959, p. 456) Sethocapsa pyriformis Haeckel (1887, p. 1310, Plate 57, Figure 2).

Eusyringium lagena (Ehrenberg) (?) (Plate 8, Figures 5,6 and 7);

[?] Lithopera lagena Ehrenberg, 1873, p. 241; 1875, Plate 3, Figure 4.

[?] Sethocapsa lagena (Ehrenberg), Haeckel, 1887, p. 1310.

[?] Sethocapsa pyriformis Haeckel, 1887, p. 1310, Plate 57, Figure 2.

Cephalis subspherical, with few small pores, bearing a stout conical horn. Thorax pyriform with no appendages, thick wall, subcircular pores, and very constricted mouth. Some late specimens have an abdomen in the form of a narrow tube with very thin wall and irregular pores (commonly elongated longitudinally).

Length to base of thorax 110 to $170 \mu$, maximum breadth 70 to $115 \mu$.

Remarks: The ancestry of this species is uncertain, but it may have arisen from a form such as Dictyophimus babylonis by loss of the feet.

Eusyringium fistuligerum (Ehrenberg) (Plate 8, Figures 8 and 9):

[?] Eucyrtidium tubulus Ehrenberg, 1854, Plate 36, Figure $19 ; 1873$, p. $233 ; 1875$, Plate 9, Figure 6.

[?] Theosyringium tubulus (Ehrenberg), Haeckel, 1887, p. 1410 .
Eucyrtidium fistuligerum Ehrenberg, 1873, p. 229; 1875, Plate 9, Figure 3.

Eusyringium fistuligerum (Ehrenberg), Haeckel, 1887, p. 1498.

Eucyrtidium sipho Ehrenberg, 1873, p. 233; 1875, Plate 9, Figure 2.

Eusyringium sipho (Ehrenberg), Haeckel, 1887, p. 1497.

Cephalis thick-walled, subspherical, with very few small pores, bearing a thick conical spine with rough surface, approximately as broad at the base as the cephalis itself. Collar stricture indistinct. Thorax thickwalled, pyriform in early specimens to almost fusiform in some late specimens, with circular pores which are larger distally than proximally. Occasionally, the thorax bears three inconspicuous wings proximally. In some specimens, a stricture separates off the narrower proximal part of the thorax. Abdomen narrow, tubular, of variable length, with irregular subcircular pores and a wall which is thinner than that of the thorax in early specimens and similar to that of the thorax in late specimens. In late specimens the junction between thorax and abdomen is obscured, the one merging imperceptibly into the other.

Length to base of thorax 135 to $225 \mu$, maximum breadth 60 to $150 \mu$.

Remarks: Only specimens with a moderately robust abdominal wall are here assigned to Eusyringium fistuligerum, those with a very tenuous abdomen being assigned to Eusyringium lagena (?). The presence of a stricture in some specimens between the narrower proximal and broader distal parts of the thorax seems to be of little importance, being developed strongly in some individuals, weakly in others, and not at all in still others.

\section{Genus Sethochytris Haeckel}

Sethochytris Haeckel (1881, p. 433). Type species (indicated by Campbell, 1954, p. 124) Sethochytris triconiscus Haeckel (1887, p. 1239, Plate 57, Figure 13). Although we have not been able to find $S$. triconiscus at its type locality: the sediment sample from Challenger Station 268, that sample does contain a little Eocene admixture indicated by rare specimens of the Lithocyclia ocellus group, Theocampe mongolfieri and Lithochytris vespertilio.

It might appear more convenient (for stability of nomenclature) to use Dictyophimus Ehrenberg as the generic name of the two species described below, but the correct type species of that genus seems not to be closely related to them. Campbell $(1954$, p. 122) designated Lychnocanium lucerna Ehrenberg as the type species of Dictyophimus, but the facts that the first species described in this genus are $D$. crisiae Ehrenberg 
and D. (?) tethyis Ehrenberg, and that the latter was questionably assigned, lead to the conclusion that the type species should be $D$. crisiae Ehrenberg (1854, p. 241) as indicated by Nigrini (1967, p. 66).

Sethochytris babylonis (Clark and Campbell) group (Plate 9, Figures 1, 2 and 3):

Dictyophimus babylonis Clark and Campbell, 1942, p. 67, Plate 9, Figures 32 and 36.

Lychnocanium lucerna Ehrenberg, 1847b, Figure 5; 1854, Plate 36, Figure 6; 1873, p. 244.

Included in this group of at least superficially similar species are a wide variety of forms with small spherical cephalis, pyriform to tetrahedral thorax with very restricted mouth, and robust cylindrical or conical feet and horn. This group is widespread and long-ranging, and its component species have not yet been satisfactorily differentiated. Excluded from the group are very large forms with inflated pyriform thorax (Plate 8 , Figure 10) and forms with three-bladed feet. The length of the shell (excluding feet and horn) in the Sethochytris babylonis group is 95 to $155 \mu$, and its breadth 80 to $150 \mu$.

Sethochytris triconiscus Haeckel (?) (Plate 9, Figure 6): Rhopalocanium ? Bury, 1862, Plate 5, Figure 4.

[?] Lithochytris barbadensis Ehrenberg, 1875, p. 160, Plate 5, Figure 2.

[?] Sethochytris triconiscus Haeckel, 1887, p. 1239, Plate 57, Figure 13.

Cephalis poreless, spherical, bearing a stout conical horn. Thorax pyriform with circular pores, drawn out in its distal part into three divergent cylindrical porous tubes, which are open terminally. In some specimens, a rib terminating in a short free spine can be distinguished in the outer wall of the distal portion of these tubes.

Total length of skeleton 150 to $210 \mu$, its total breadth 100 to $170 \mu$.

Remarks: Although this species superficially resembles some species of Lithochytris, it is clearly developed from a member of the Sethochytris babylonis group, as is indicated by the transitional forms illustrated on Plate 9, Figures 4 and 5. Lithochytris barbadensis may be one such transitional form.

\section{Genus Lithochytris Ehrenberg}

Lithochytris Ehrenberg, 1847a, chart to p. 385. Type species (indicated by Campbell, 1954, p. 132) Lithochytris vespertilio Ehrenberg (1873, p. 239; 1875, Plate 4, Figure 10).
Lithochytris archaea is evidently the earliest species of this genus, and indicates its origin from a probably open podocyrtid (possibly resembling that illustrated on Plate 10, Figure 1).

Lithochytris archaea, new species (Plate 9, Figure 7):

Cephalis spherical, with a few small pores and bearing a stout conical horn of about the same length to three times the length. Collar stricture distinct in some specimens, not in others. Thorax inflatedhemispherical, with thick wall and circular pores. Lumbar stricture distinct. Abdomen joined to the divergent feet through most of their length, with circular pores and truncate distally. The three feet are strong and prominent; throughout the length of the abdomen they are evident as prominent ridges beyond the surface of the abdominal wall, and their free distal portions are robust and cylindro-conical.

Total length 180 to $270 \mu$, maximum breadth 125 to $195 \mu$.

Remarks: The distinction from Lithochytris vespertilio is given under that heading. Many of the specimens in older assemblages have the feet less integrated into the abdominal wall, and the abdomen longer and less triangular, than in the holotype.

Lithochytris vespertilio Ehrenberg (Plate 9, Figures 8 and 9):

Lithochytris vespertilio Ehrenberg, 1873, p. 239; 1875, Plate 4, Figure 10.

Lithochytris lucerna Haeckel, 1887, p. 1364, Plate 67, Figure 14.

Lithochytris cheopsis Clark and Campbell, 1942, p. 81, Plate 9, Figure 37.

Cephalis subspherical, with few small pores, bearing a short, stout conical horn. Thorax small, inflatedhemispherical, with circular pores. Some early specimens have a slight collar stricture, but in late specimens the horn, cephalis and thorax together tend to have a smooth contour, set off from the abdomen by a change in contour. Abdomen almost tetrahedral (truncated proximally and closed distally) in form, the three distal corners prolonged into structures resembling stubby, proximally latticed, distally robust and conical feet. The homologues of the proximal parts of the feet of Lithochytris archaea are reduced to ribs within the abdominal wall at the edges of the tetrahedron. Abdominal pores are subcircular, and the entire shell is thick-walled.

Total length 200 to $260 \mu$, maximum breadth 135 to $250 \mu$. 
Remarks: This form differs from Lithochytris archaea in having shorter free distal feet, and in having the part of the feet from the collar stricture to the end of the abdomen reduced to ribs within the abdominal wall. It is interesting to note that, while early specimens are invariably longer than they are wide, a considerable number of the late specimens closely approach the proportions of a regular tetrahedron.

\section{Genus Lychnocanium Ehrenberg}

Lychnocanium Ehrenberg, 1847a, chart to p. 385. Type species (desginated by Campbell, 1954, p. 124) Lychnocanium falciferum Ehrenberg (1854, Plate 36, Figure $7 ; 1875$, p. 160, Plate 8, Figure 4).

It is not yet possible to specify appropriate limits for the genus Lychnocanium, and the following two species are assigned here more as a matter of temporary convenience than from any conviction that they are closely related to each other and to the type species. It may eventually prove desirable to synonymize some or all of the following genus-group taxa with Lychnocanium:

Acerahedrina Vinassa, 1900 , p. 581 . Type species (by monotypy). Acerahedrina hirta Vinassa (1900, p. 581. Plate 2, Figure 32).

Acerocanium Vinassa, 1900, p. 580. Type species (by monotypy) Acerocanium globosum Vinassa (1900, p. 581, Plate 2, Figure 28).

Lithornithium Ehrenberg, 1847b, chart to p. 54. Type species (indicated by Campbell, 1954, p. 132) Lithocampe hirundo Ehrenberg (1840, p. 200; 1854, Plate 19, Figure 53).

Lychnocanoma Haeckel, 1887, p. 1229. Type species (designated by Campbell, 1954, p. 124) Lychnocanium clavigerum Haeckel (1887, p. 1230, Plate 61, Figure 4).

Lychnocanium bellum Clark and Campbell (Plate 10, Figure 5):

Lychnocanium bellum Clark and Campbell, 1942, p. 72, Plate 9, Figures 35 and 39.

Lychnocanium sp., Riedel, 1957b, p. 259, Plate 63, Figure 5.

Lychnocanium bipes Riedel (Plate 15, Figure 8):

Lychnocanium bipes Riedel, 1959, p. 294, Plate 2, Figures 5 and 6.

\section{Genus Pterocanium Ehrenberg}

Pterocanium Ehrenberg, 1847a, chart to p. 385. Type species (indicated by Campbell, 1954, p. 130) Pterocanium proserpinae Ehrenberg $(1858$, p. $39 ; 1872 \mathrm{~b}$ Plate 11, Figure 22).
[?] Lamprodiscus Ehrenberg, 1860, p. 831. Type species (designated by Campbell, 1954, p. 122) Lamprodiscus monoceros Ehrenberg (1872a, p. 314; 1872b, Plate 7, Figure 2).

Pleuropodium Haeckel, 1881, p. 436. Type species (indicated by Campbell, 1954, p. 130) Podocyrtis charybdea Müller (1855, p. 673; 1858, Plate 6, Figures 7 through 10).

Pterocanidium Haeckel, 1887, p. 1332. Type species (designated by Campbell, 1954, p. 130) Pterocanium eucolpum Haeckel (1887, p. 1332, Plate 73, Figure 4).

It is not yet possible to define satisfactorily the limits of this genus, but it seems clear that the following species is closely related to its type species.

Pterocanium prismatium Riedel:

Pterocanium prismatium Riedel, 1957a, p. 87, Plate 3, Figures 4 and 5.

The original description of this species admitted specimens without thorns on the three thoracic ribs, but such forms are now excluded.

\section{Genus Cycladophora Ehrenberg}

Cycladophora Ehrenberg, 1847a, chart to p. 385. Type species (indicated by Campbell, 1954, p. 132) Cycladophora stiligera Ehrenberg (1873, p. 223; 1875, Plate 18, Figure 3).

Calocyclas Ehrenberg, 1847b, chart to p. 54. Type species (indicated by Campbell, 1954, p. 132) Calocyclas turris Ehrenberg (1873, p. 218; 1875, Plate 18, Figure 7).

Cycladophora hispida (Ehrenberg) (Plate 10, Figure 9): Anthocyrtis hispida Ehrenberg, 1873, p. 216; 1875, Plate 8, Figure 2.

Cycladophora turris (Ehrenberg), (Plate 13, Figures 3 and 4):

Calocyclas turris Ehrenberg, 1873, p. 218; 1875, Plate 18, Figure 7.

Cycladophora stiligera Ehrenberg, 1873, p. $223 ; 1875$, Plate 18, Figure 3.

Cycladophora turris evidently developed from C. hispida by the feet becoming joined to form an abdomen.

Genus Lophocyrtis Haeckel

Lophocyrtis Haeckel, 1887, p. 1410. Type species (designated by Campbell, 1954, p. 134) Eucyrtidium stephanophorum Ehrenberg (1873, p. 233; 1875, Plate 8 , Figure 14). 
Lophocyrtis (?) jacchia (Ehrenberg):

Thyrsocyrtis jacchia Ehrenberg, 1873, p. 261; 1875, Plate 12, Figure 7.

Thyrsocyrtis dionysia Ehrenberg, 1873, p. 260; 1875, Plate 12, Figure 5.

[?] Eucyrtidium stephanophorum Ehrenberg, 1873, p. $233 ; 1875$, Plate 8 , Figure 14.

[?] Podocyrtis amphiacantha Ehrenberg, 1873, p. $248 ; 1875$, Plate 17, Figure 2.

It is not yet possible to demonstrate a close relationship between Lophocyrtis (?) jacchia and the type species of this genus, and therefore the generic assignment is only tentative. Early forms of $L$. (?) jacchia appear possibly to be related to Dictyopodium eurylophos (1873, p. 223; 1875, Plate 19, Figure 4), which was indicated as the type species of Dictyopodium Ehrenberg (1847b, chart to p. 54) by Campbell (1954, p. 130).

\section{Genus Theocorys Haeckel}

Theocorys Haeckel, 1881, p. 434. Frizzell and Middour (1951, p. 30) designated Eucyrtidium turgidulum Ehrenberg (1872a, p. 312; 1872b, Plate 7, Figure 13) as the type species of this genus, and Strelkov and Lipman (1959, p. 457) indicated that the type species is Theocorys veneris Haeckel (1887, p. 1415, Plate 69, Figure 5), but Campbell (1954, p. 134) was legally correct in indicating, as the type species, the first species described in the genus (Theocorys morchellula Rüst, 1885, p. 308, Plate 37, Figure 6).

Assignment of the following species to Theocorys is not based on a belief that they are closely related to any of the above candidates for type species, but is only a temporary expedient pending determination of where their true relationships lie.

Theocorys anaclasta, new species (Plate 10, Figures 2 and 3):

Cephalis spherical, poreless or with few small pores, bearing a stout conical horn of variable length. Collar and lumbar strictures distinct. Thorax conical to hemispherical, with small subcircular pores. Abdomen broader than thorax, with thick wall (less robust in late specimens) and large rounded pores. Abdomen inflated in its main part, then constricting distally and expanded terminally, lacking distinct terminal ring. Proximal part of abdomen often thorny, and thorax less so.

Length (excluding horn) 225 to $390 \mu$, maximum breadth 135 to $235 \mu$. Measurements based on 20 specimens.
Theocorys anapographa, new species (Plate 10, Figure 4):

Cephalis spherical, poreless or with a few small pores, bearing a thin conical horn of about the same length. Collar and lumbar strictures distinct. Thorax conical to campanulate, with pores subcircular or irregular, commonly of various sizes. Abdomen subcylindrical, broader and commonly longer than the thorax, usually increasing in width distally especially in late specimens. Abdominal pores rounded, irregular in size and shape, larger than those of the thorax, increasing in size distally. Thoracic and abdominal wall sometimes thorny.

Length (excluding horn) 140 to $220 \mu$, maximum breadth 110 to $155 \mu$.

Remarks: This species is probably closely related to the form illustrated as Clathrocyclas sp. by Nigrini (Plate 4, Figure 2) in her report on Eocene radiolarians from Leg 2 of this Deep-Sea Drilling program.

\section{Genus Stichocorys Haeckel}

Stichocorys Haeckel, 1881, p. 438. Type species (indicated by Campbell, 1954, p. 140) Stichocorys wolffii Haeckel (1887, p. 1479, Plate 80, Figure 10).

\section{Stichocorys wolffii Haeckel:}

Stichocorys wolffii Haeckel, 1887, p. 1479, Plate 80, Figure 10; Riedel, 1957a, p. 92, Plate 4, Figures 6 and 7.

Stichocorys delmontensis (Campbell and Clark) (Plate 14, Figure 6):

Eucyrtidium delmontense Campbell and Clark, 1944a, p. 56, Plate 7, Figures 19 and 20; Riedel, 1952, p. 8, Plate 1, Figure 5; Riedel, 1957a, p. 93.

Stichocorys peregrina (Riedel):

Eucyrtidium elongatum peregrinum Riedel, 1953, p. 812, Plate 85, Figure 2; Riedel, 1957a, p. 94.

\section{Genus Cyrtocapsella Haeckel}

Cyrtocapsella Haeckel, 1887, p. 1512. Type species (designated by Campbell, 1954, p. 143) Cyrtocapsa tetrapera Haeckel (1887, p. 1512, Plate 78, Figure 5).

Syringium Principi, 1909, p. 19. Type species (by monotypy) Syringium vinassai Principi (1909, p. 19, Plate 1, Figure 60).

[?] Eusyringoma Haeckel, 1887, p. 1498. Type species (designated by Frizzell and Middour, 1951, p. 35) Eucyrtidium lagenoides Stöhr (1880, p. 104, Plate 20, Figure 8).

Cyrtocapsella tetraperaHaeckel (Plate 14, Figure 7):

Cyrtocapsa tetrapera Haeckel, 1887, p. 1512, Plate 78, Figure 5; (cf.) Nakaseko, 1955, p. 119, Plate 11, Figure 7. 
Cyrtocapsa compacta Haeckel, 1887, p. 1512, Plate 77, Figure 8; Nakaseko, 1955, p. 119, Plate 11, Figure 6.

Cyrtocapsa pyrum Haeckel, 1887, p. 1513, Plate 78, Figure 8.

[?] Eucyrtidium globicephalum Vinassa, 1890, p. 586, Plate 3, Figure 23.

Theocapsa elongata Vinassa, 1900, p. 584, Plate 3, Figure 8.

Tricolocapsa hexagonata Vinassa, 1900, p. 584, Plate 3, Figure 9.

[?] Tricolocapsa elliptica Vinassa, 1900, p. 584, Plate 3, Figure 10.

Eusyringium haeckelianum Vinassa, 1900, p. 587, Plate 3, Figure 25.

[?] Eusyringium oligoporum Vinassa, 1900, p. 587, Plate 3, Figure 26.

Eusyringium marianii Vinassa, 1900, p. 587; Plate 3, Figure 27.

Cyrtocapsa rothpletzi Vinassa, 1900, p. 588, Plate 33, Figure 34.

Cyrtocapsa brevicornis Vinassa, 1900, p. 589, Plate 3, Figure 35.

Cyrtocapsa hirta Vinassa, 1900, p. 589, Plate 3, Figure 36.

Cyrtocapsa macropora Vinassa, 1900, p. 589, Plate 3, Figure 37.

Cyrtocapsa strangulata Vinassa, 1900, p. 589, Plate 3, Figure 38.

[?] Cyrtocapsa bicornis Vinassa, 1900, p. 589, Plate 3 , Figure 39.

Cyrtocapsa miocenica Vinassa, 1900, p. 590, Plate 3, Figure 42; Lucchese, 1927, p. 108, Plate 8, Figure 15.

Cyrtocapsa miocenica laevicauda Vinassa, 1900, p. 590, Plate 3, Figure 43.

Stichocapsa hexagona Vinassa, 1900, p. 590, Plate 3, Figure 44.

[?] Stichocapsa elongata Vinassa, 1900, p. 590, Plate 3 , Figure 45.

[?] Stichocapsa laevigata Vinassa, 1900, p. 590, Plate 3, Figure 46.

Stichocapsa macropora Vinassa, 1900, p. 591, Plate 3, Figure 47; Martin, 1904, p. 451, Plate 130, Figures 6 and 7.

Stichocapsa hirta Vinassa, 1900, p. 591, Plate 3, Figure 48.

Stichocapsa strangulata Vinassa, 1900, p. 591, Plate 3, Figure 49.

Stichocapsa longicauda Vinassa, 1900, p. 591, Plate 3, Figure 50.
Artocapsa dunikowskyi Vinassa, 1900, p. 591, Plate 3, Figure 51.

Eucyrtidium isseli Principi, 1909, p. 18, Plate 1, Figure 56.

Eusyringium curvispina Principi, 1909, p. 18, Plate 1, Figure 59.

Syringium vinassai Principi, 1909, p. 19, Plate 1, Figure 60.

Cyrtocapsa poligonalis Principi, 1909, p. 19, Plate 1, Figure 61.

Cyrtocapsa marinellii Principi, 1909, p. 19, Plate 1, Figure 63.

[?] Stic[h] ocapsa brevicauda Principi, 1909, p. 20, Plate 1, Figure 65.

[?] Theocapsa piriformis Lucchese, 1927, p. 106, Plate 8, Figure 6.

Eucyrtidium lagenoides Stöhr; Lucchese, 1927, p. 107, Plate 8, Figure 11, [non E. lagenoides Stöhr] .

Eucyrtidium globicephalum Vinassa; Lucchese, 1927, p. 108, Plate 8, Figure 13.

Cyrtocapsa miocenica imperforaticauda Lucchese, 1927, p. 109, Plate 8, Figure 16.

Eucyrtidium ichikawai Nakaseko, 1955, p. 112, Plate 11, Figures 1, 3 and 5; Nakaseko and Chiji, 1964, p. 91 , text-figure 5 .

Eusyringium nipponicum Nakaseko, 1955, p. 114, Plate 10, Figure 10; Plate 11, Figure 2.

[?] Eusyringium yatsuoense Nakaseko, 1955, p. 115, Plate 11, Figure 4.

Cyrtocapsa subconica Nakaseko, 1955, p. 120, Plate 11, Figure 9.

Podocampe yatsuoensis Nakaseko, 1955, p. 127, Plate 11, Figure 8.

Cyrtocapsa miocenica Vinassa ?; Bachmann, Papp and Stradner, 1963, p. 129, Plate 6, Figure 24.

Cyrtocapsella cornuta Haeckel (Plate 14, Figure 8):

Cyrtocapsa cornuta Haeckel, 1887, p. 1513, Plate 78, Figure 9.

[?] Eucyrtidium lagenoides Stöhr, 1880, p. 104, Plate 20, Figure 8.

Eucyrtidium typus Vinassa, 1900, p. 587, Plate 3, Figure 24.

Lithocampe micropyle Vinassa, 1900, p. 587, Plate 3 , Figure 28.

Cyrtocapsella elongata (Nakaseko):

Theocapsa elongata Nakaseko, 1963, p. 185, Plate 3, Figures 4 and 5. 
Cyrtocapsella japonica (Nakaseko) (Plate 14, Figure 9):

Eusyringium japonicum Nakaseko, 1963, p. 193, textfigures 20 and 21, Plate 4, Figures 1, 2, and 3.

[?] Dicolocapsa elongata Vinassa, 1900, p. 582, Plate 2, Figure 36.

[?] Theocapsa cayeuxi Vinassa, 1900, p. 584, Plate 3, Figure 7.

Theocapsa himiensis Nakaseko, 1963, p. 184, textfigure 15, Plate 3, Figures 1, 2 and 3.

Eusyringium isozakiense Nakaseko, 1963, p. 194, Plate 4, Figures 5, 6 and 7, 11 and 12.

\section{Genus Artophormis Haeckel}

Artophormis Haeckel, 1881, p. 438. Type species (indicated by Campbell, 1954, p. 139) Artophormis horrida Haeckel (1887, p. 1458, Plate 75, Figure 2).

Although it seems very unlikely that the three following species are closely related to the type species of this genus, the generic name is retained because it seems inappropriate to erect a new genus for them in this paper dealing with samples in which they are not well represented-this will be done in a paper on the radiolarians of Barbados which is in preparation.

Artophormis dominasinensis (Ehrenberg):

Podocyrtis dominasinensis Ehrenberg, 1873, p. 250; 1875, Plate 14, Figure 4.

Podocyrtis brevipes Ehrenberg, 1873, p. 249; 1875, Plate 16, Figure 6.

Eucyrtidium apiculatum Ehrenberg, 1873, p. 225; 1875, Plate 10, Figure 10.

Although Ehrenberg's original figure of this species shows an apparently three-lobed cephalis, our examination of specimens from Barbados leads us to conclude that this species is not a pterocoryid because when its cephalis is bulged this is not in the regular manner characteristic of that family. Our form is apparently not the same as that recorded as ? Clathrocyclas dominasinensis by Nigrini in her report on the radiolarians from Leg 2 of this expedition.

Artophormis barbadensis (Ehrenberg) (Plate 13, Figure 5):

Calocyclas barbadensis Ehrenberg, 1873, p. 217; 1875, Plate 18, Figure 8.

Cephalis spherical, with thorny surface and a moderate number of small subcircular pores, bearing a loosely spongy (occasionally latticed-bladed) apical horn. Collar stricture pronounced. Thorax inflated-campanulate, with thorny surface and subcircular pores. Lumbar stricture distinct. Abdomen tending to be somewhat longer than thorax and with slightly thinner wall, truncate-conical, with thorny surface and irregular subcircular pores. Fourth segment short, formed of very irregular latticework of which some elements are longitudinal ribs which commonly extend a short distance as free terminal spines. No differentiated termination of fourth segment.

Measurements based on 7 specimens from Site 29 and 37 from the Oceanic Formation at Bath, Barbados. Length of first three segments (excluding horn) 95 to $145 \mu$. Maximum breadth of the abdomen 70 to $120 \mu$. Ratio of abdomen length: thorax length (0.8-1.8): 1 .

Remarks: This species is distinguished from $A$. gracilis by the abdomen being longer and truncate-conical rather than inflated, and by the fourth segment being less developed. It is distinguished from A. dominasinensis by the generally latticed horn, proportionately shorter abdomen, and the development of a fourth segment.

Artophormis gracilis Riedel (Plate 13, Figures 6 and 7): Artophormis gracilis Riedel, 1959, p. 300, Plate 2, Figures 12 and 13.

\section{Genus Phormocyrtis Haeckel}

Phormocyrtis Haeckel, 1887, p. 1368. Type species (designated by Campbell, 1954, p. 134) Phormocyrtis longicornis Haeckel (1887, p. 1370, Plate 69, Figure $15)$.

It seems very unlikely that the following species is closely related to the type species of this genus, but it is retained here until its relationships are understood.

Phormocyrtis striata Brandt (Plate 10, Figure 7):

Phormocyrtis striata Brandt, 1935, in Wetzel, 1935, p. 55, Plate 9, Figure 12.

Cephalis hemispherical, with samll pores, and bearing a bladed horn of about the same length or somewhat longer. Collar stricture indistinct. Thorax inflated-hemispherical, with circular pores irregularly arranged. Lumbar stricture distinct. Abdomen (constituting the main part of the shell) fusiform, its greatest breadth usually near the middle, with circular pores in longitudinal rows usually separated by ridges. Termination ragged, toothed, or in rare specimens closed.

Total length 170 to $255 \mu$, maximum breadth 70 to $100 \mu$.

Remarks: In assemblages older than those described here (very early Eocene or Paleocene) the abdomen of this species tends to be triangular in cross section. 


\section{Genus Lithocampium Haeckel}

Lithocampium Haeckel, 1881, p. 437. Type species (indicated by Campbell, 1954, p. 141) Lithocampium stabile Rüst (1885, p. 311, Plate 38, Figure 6).

Assignment of the following species to this genus does not result from a belief that it is closely related to the type species, but is only a matter of convenience pending determination of its relationships.

Lithocampium sp. (Plate 10, Figure 8):

Cephalis subspherical, with few small pores, bearing a bladed horn of about the same length. Collar and subsequent strictures not expressed externally. Thorax truncate-conical or slightly inflated, with circular pores irregularly arranged. Third segment the largest, barrel-shaped, with circular pores regularly quincuncially arranged. Fourth segment shorter, thinnerwalled, with pores in transverse rows and tapering to the unrimmed mouth.

Total length 115 to $170 \mu$, maximum breadth 65 to $85 \mu$.

Remarks: This species bears a superficial resemblance to Lithocampe turgida Krasheninnikov (1960, p. 301, Plate 3, Figure 17), but the latter is much larger and has its greatest breadth near the base of the third segment.

\section{Family PTER OCOR YIDAE Haeckel}

Pterocoryidae Haeckel, 1881, emend. Riedel, 1967b, p. 296.

\section{Genus Podocyrtis Ehrenberg}

Podocyrtis Ehrenberg, 1847a, chart to p. 385. Type species (indicated by Campbell, 1954, p. 130) Podocyrtis papalis Ehrenberg (1847a, Figure 2; 1854, Plate 36, Figure 23; 1873, p. 251).

\section{Subgenus Podocyrtis Ehrenberg}

Podocyrtis (Podocyrtidium) Haeckel, 1887, p. 1344.

Podocyrtis (Podocyrtis) in Campbell, 1954, p. 130.

To this nominate subgenus are assigned the members of the lineage leading from Podocyrtis papalis to P. ampla, inclusive.

Podocyrtis (Podocyrtis) papalis Ehrenberg (Plate 11, Figure 1):

Podocyrtis papalis Ehrenberg, 1847b, Figure 2; 1854, Plate 36, Figure 23; 1873, p. 251.

Podocyrtis fasciata Clark and Campbell, 1942, p. 80, Plate 7, Figures 29 and 33.
Cephalis is subhemispherical, with many small pores, bearing a horn of variable length which is usually threebladed, sometimes conical. Collar stricture marked by change in contour. Thorax inflated-conical, with circular pores in longitudinal rows separated by ribs. Lumbar stricture not (or only very slightly) expressed externally. Abdomen inverted truncate-conical, with pores and ribs similar to those of thorax. Pored part of abdomen generally shorter than thorax, and this is followed by a poreless part of the abdominal wall from which arise three large, shovel-shaped feet.

Length (excluding horn) 170 (rarely 150 ) to $280 \mu$, maximum breadth 95 to $140 \mu$.

Remarks: This form is here described very broadly, and later careful study may prove the desirability of separating it into several species or subspecies.

Podocyrtis (Podocyrtis) diamesa, new species (Plate 12, Figures 4, 5 and 6):

Cephalis elongate-hemispherical, with small pores, bearing a horn of variable length which is bladed in early specimens, conical and robust in late specimens. Collar stricture marked by change in contour. Thorax inflated-conical, with pores circular and in longitudinal rows separated by ridges in early specimens, larger and lacking intervening ridges. in late specimens. Thorax and abdomen of variable proportions, but often of approximately the same length. Slight lumbar stricture. Abdomen tapering distally, sometimes slightly inflated. Abdominal pores subcircular in longitudinal rows, in early specimens similar in size to distal thoracic pores and separated by longitudinal ridges, in late specimens larger and lacking longitudinal ridges. Three feet shovelshaped, irregular in some specimens with very restricted aperture.

Length (excluding horn) 220 to $360 \mu$, maximum breadth 140 to $180 \mu$.

Remarks: This form is clearly transitional, early specimens approaching Podocyrtis papalis and late ones Podocyrtis ampla. It differs from $P$. papalis in its larger size and the presence of a lumbar stricture, and from $P$. ampla in its general form being spindle-shaped rather than conical.

Podocyrtis (Podocyrtis) ampla Ehrenberg (Plate 12, Figures 7 and 8):

Podocyrtis (?) ampla Ehrenberg, 1873, p. 248, 1875, Plate 16, Figure 7.

Cephalis subspherical, with few small pores, bearing a stout conical horn of variable length. Collar and lumbar strictures not pronounced. Thorax conical, of approximately the same length as the abdomen, 
with circular pores in longitudinal rows separated by ridges. Abdomen truncate-conical or subcylindrical, slightly inflated, with pores, larger than those of the thorax, usually arranged in approximate longitudinal rows without intervening ridges. Abdomen terminates in a narrow, thickened rim from which arise (in early specimens only) three small, shovel-shaped or spathulate feet.

Length (excluding horn and feet) 240 to $280 \mu$, maximum breadth 170 to $205 \mu$.

Remarks: This species is distinguished from Podocyrtis diamesa by being conical rather than spindle-shaped, in general form. An interesting feature is the narrow, thickened rim terminating the abdomen, which is foreshadowed by some late specimens of $P$. diamesa having the poreless distal part of the abdominal wall narrower than that of earlier specimens.

\section{Subgenus Lampterium Haeckel}

Lampterium Haeckel, 1881, p. 434. Type species (indicated by Campbell, 1954, p. 132) Cycladophora goetheana Haeckel (1887, p. 1376, Plate 65, Figure 5).

Podocyrtonium Haeckel, 1887, p. 1347. Type species (designated by Campbell, 1954, p. 130) Podocyrtis pedicellaria Haeckel $(1887$, p. 1347, Plate 72 , Figure 8).

This subgenus comprises those forms (beginning with Podocyrtis aphorma) that developed from Podocyrtis papalis and evolved into Podocyrtis chalara. It appears highly probable that Cycladophora goetheana Haeckel and similar forms represent the culmination of this lineage, and that the following genus-group taxa should therefore be synonymized with Lampterium:

Lamptidium Haeckel, 1887, p. 1377. Type species (designated by Campbell, 1954, p. 132) Cycladophora hexapleura Haeckel (1887, p. 1377; Bury, 1867, Plate 13, Figure 7).

Tetralacorys Haeckel, 1881 , p. 436 . Type species (indicated by Campbell, 1954, p. 132) Alacorys lutheri Haeckel (1887, p. 1370, Plate 65, Figure 4).

Podocyrtis (Lampterium) aphorma, new species (Plate 11, Figure 2):

Cephalis hemispherical, with many small pores, bearing a three-bladed horn of about the same length. Collar stricture marked by change in contour. Thorax inflated campanulate, with subcircular pores in longitudinal rows separated by ribs. Lumbar stricture moderate to indistinct. Abdomen subcylindrical, slightly inflated or simply tapering distally, of approximately the same width as the thorax, with pores subcircular to longitudinally elongate, arranged less regularly than on thorax. Porous part of abdomen shorter than thorax. Three feet broad, shovel-shaped, arising as prolongations of poreless distal part of abdomen.

Total length 155 to $240 \mu$, maximum breadth 95 to $110 \mu$.

Remarks: This species is distinguishable from $P$. papalis only by the less regular abdominal pores and the presence of a slight lumbar stricture. Specimens more typical (with less regular abdominal pores) than the holotype occur in older assemblages.

Podocyrtis (Lampterium) sinuosa Ehrenberg(?) (Plate 11, Figures 3 and 4):

[?] Podocyrtis sinuosa Ehrenberg, 1873, p. 253; 1875, Plate 15, Figure 5.

Podocyrtis mitra Ehrenberg, in Ehrenberg, 1875, Plate 15, Figure 4 [non Ehrenberg, 1854, Plate 36, Figure B20].

Cephalis hemispherical, with many small pores, and bearing a three-bladed horn of about the same length. Collar stricture marked by a change in contour, obscure in late specimens. Thorax campanulate (conical in some late specimens); and the abdomen subcylindrical, slightly inflated, both segments with subcircular pores in longitudinal rows usually (but not in some late specimens) separated by longitudinal ribs. Pores of the abdomen larger than those of thorax. Lumbar stricture moderate to slight. Three feet are broad, arising from poreless distal rim of abdomen, generally shovel-shaped but spathulate in some late specimens.

Thorax in early specimens 55 to $80 \mu$ long and 85 to $110 \mu$ wide; in late specimens 45 to $60 \mu$ long and 85 to $95 \mu$ wide. Length of abdomen plus feet in early specimens 125 to $180 \mu$, in late specimens 145 to $225 \mu$. Maximum breadth of abdomen in early specimens 115 to $140 \mu$, in late specimens 135 to $170 \mu$.

Remarks: This species is distinguished from Podocyrtis aphorma by the larger abdomen, and from $P$. trachodes by the smoother surface. With time, the abdomen increases in size while the thorax decreases.

Podocyrtis (Lampterium) mitra Ehrenberg (Plate 11, Figures 5 and 6):

Podocyrtis mitra Ehrenberg, 1854, Plate 36, Figure B20; 1873 , p. 251; [non Ehrenberg, 1875, Plate 15, Figure 4].

Podocyrtis eulophos Ehrenberg, 1873, p. 251; 1875, Plate 14, Figure 6.

[?] Podocyrtis pedicellaria Haeckel, 1887, p. 1347, Plate 72, Figure 8. 
Cephalis hemispherical, with few to many small pores, bearing a bladed horn of about the same length. Thorax thick-walled, conical to campanulate, with usually rather large subcircular pores and rough surface. Collar and lumbar strictures distinct. Abdomen thick-walled, expanding distally and contracting abruptly near its end, with large subcircular pores longitudinally aligned and in some specimens with the rows separated by ribs. Abdominal pores in many specimens have delicate spines projecting into them from their periphery. Abdominal surface is usually smooth, sometimes rough. Three feet short and flat, spathulate or triangular, or absent.

Thorax 55 to $80 \mu$ long, 80 to $100 \mu$ wide. Length of abdomen plus feet 125 to $250 \mu$. Maximum breadth of abdomen 110 to $180 \mu$.

Remarks: This species differs from $P$. sinuosa and $P$. trachodes in having its abdomen widest near the distal end rather than medially.

Podocyrtis (Lampterium) trachodes, new species (Plate 11, Figure 7; Plate 12, Figure 1):

Cephalis hemispherical, with many small pores, bearing a three-bladed horn of about the same length. Thorax campanulate and abdomen moderately inflated, broadest at about its mildde; both segments thick-walled with rough surfaces and with subcircular pores, larger in abdomen than in thorax, in indistinct longitudinal rows. Collar and lumbar strictures moderately distinct. Three feet short and flat, spathulate or triangular. In occasional specimens, feet are absent.

Thorax 45 to $70 \mu$ long, 85 to $100 \mu$ wide. Abdomen plus feet 135 to $220 \mu$ long. Greatest breadth of abdomen 135 to $170 \mu$.

Remarks: This species is distinguished by the rough surface of its thorax and (especially) abdomen.

Podocyrtis (Lampterium) chalara, new species (Plate 12, Figures 2 and 3 ):

[?] Podocyrtis (?) sp. Bury, 1862, Plate 12, Figure 2.

Cephalis irregularly hemispherical, with few to many small pores, and bearing a stubby bladed horn. Thorax thick-walled with rough surface approximately hemispherical, with rather large subcircular pores. Collar and lumbar strictures distinct. Abdomen robust, with smooth surface, of very large subangular meshes usually in approximate longitudinal rows; in outer form it expands slightly, then contracts distally. Abdominal pores commonly have short thorns projecting inward from their periphery. Vestigial triangular teeth are rarely present.
Thorax 40 to $65 \mu$ long, 80 to $95 \mu$ wide. Abdomen 155 (rarely 85 ) to $255 \mu$ long and 125 (rarely 100) to $165 \mu$ wide.

Remarks: This species differs from Podocyrtis mitra in having larger abdominal pores, and in generally lacking feet.

Podocyrtis (Lampterium) goetheana (Haeckel):

Cycladophora goetheana Haeckel, 1887, p. 1376, Plate 65 , Figure 5.

Genus Theocyrtis Haeckel

Theocyrtis Haeckel, 1887, p. 1405. Type species (designated by Campbell, 1954, p. 134) Eucyrtidium barbadense Ehrenberg (1873, p. 226; 1875, Plate 9, Figure 7).

Although it is not yet possible to demonstrate satisfactorily any very close relationship between the following species assigned to this genus, it seems likely that this will be possible when more suitable material becomes available.

Theocyrtis tuberosa Riedel (Plate 13, Figures 8, 9 and 10):

Theocyrtis tuberosa Riedel, 1959, p. 298, Plate 2, Figures 10 and 11.

Theocyrtis annosa (Riedel) (Plate 15, Figure 9):

Phormocyrtis annosa Riedel, 1959, p. 295, Plate 2, Figure 7.

\section{Genus Calocycletta Haeckel}

Calocycletta Haeckel, 1887, p. 1381. Type species (designated by Campbell, 1954, p. 132) Calocyclas veneris Haeckel (1887, p. 1381, Plate 74, Figure 5).

It is not yet possible to define satisfactorily the limits of this genus, but there seems little doubt that the following two species are closely related to the type species.

Calocycletta virginis Haeckel (Plate 14, Figure 10):

Calocyclas virginis Haeckel, 1887, p. 1381, Plate 74, Figure 4; Riedel, 1959, p. 295, Plate 2, Figure 8.

Calocycletta costata (Riedel) (Plate 14, Figure 12):

Calocyclas costata Riedel, 1959, p. 296, Plate 2, Figure 9.

Family ARTOSTROBIIDAE Riedel, 1967a

Genus Theocampe Haeckel

Theocampe Haeckel, 1887, p. 1422. Type species (designated by Campbell, 1954, p. 134) Dictyomitra ehrenbergi Zittel (1876, p. 82, Plate 2, Figure 5). 
Although the genera of artostrobiids are not yet satisfactorily worked out, it seems likely that the following species is more closely related to the type species of Theocampe than it is to that of Sethamphora (a carpocaniid according to Riedel, in press, a).

Theocampe mongolfieri (Ehrenberg) (Plate 12, Figure 9):

Eucyrtidium mongolfieri Ehrenberg, 1854, Plate 36, Figure 18B; 1873, p. 230; 1875, Plate 10, Figure 3. Sethamphora mongolfieri (Ehrenberg), Haeckel, 1887, p. 1251.

Theocampe mongolfieri (Ehrenberg), Burma, 1959, p. 329.

Cephalis hemispherical, with circular pores, and with an inconspicuous lateral tubule lying against the upper part of the thoracic wall. Collar stricture indistinct. Thorax slightly inflated annular, with circular pores inclined obliquely upward and inward as they traverse the thick wall. Lumbar stricture distinct. Abdomen inflated barrel-shaped, constricted distally to a short cylindrical, hyaline peristome. Abdominal pores strictly in longitudinal and transverse rows, the longitudinal rows separated by ridges.

Total length 115 to $170 \mu$, maximum breadth 70 to $100 \mu$.

Remarks: This species is evidently derived from a form with pores in transverse but not regular longitudinal rows, which precedes and co-occurs with it.

\section{Family CANNOBOTR YIDAE Haeckel}

Cannobotryidae Haeckel, 1881, emend. Riedel, 1967b, p. 296.

The sequence obtained at Site 29 contains a form (Plate 12, Figure 10) that may represent the earliest record of this family subsequent to the forms described by Foreman (1968) as Eribotrys, but this species is rare and has not been investigated in detail.

\section{Genus Acrobotrys Haeckel}

Acrobotrys Haeckel, 1881, p. 440. Type species (indicated by Campbell, 1954 , p. 144) Acrobotrys monosolenia Haeckel (1887, p. 1114).

The limits of this genus have not been worked out satisfactorily, and assignment here of the following species is a matter of temporary convenience only.

Acrobotrys tritubus Riedel:

Acrobotrys tritubus Riedel, 1957a, p. 80, Plate 1, Figure 5.

\section{EVOLUTIONARY LINEAGES}

One of the most interesting aspects of the middle Eocene radiolarian sequence at Site 29 is the fact that even a preliminary examination has resulted in the recognition of a number of evolutionary lineages (albeit many of them comprising only two species). These lineages are listed below, together with others known from late Eocene and younger sequences. Recognition of such phylogenetic series permits a modification of the Haeckelian generic classification of the species involved, so that the taxonomic system more closely reflects natural relationships. The lineages also provide a more reliable basis for the zonation and correlation of radiolarian sequences than would be provided by cryptogenetic species.

It seems highly probable that further research will reveal additional phylogenetic series in the Site 29 material, and thus these cores and the Oceanic Formation will become increasingly valuable in advancing our understanding of the polycystine radiolarians. Factors contributing to the usefulness of these sedimentary sequences for this type of investigation include: (1) deposition within the tropics, assuring representation of a wide variety of forms; (2) apparent continuity of the sequences, without disturbing hiatuses; and, (3) representation of periods long enough to demonstrate marked evolutionary changes.

\section{Lithapium (?) anoectum - L. (?) mitra (?) Lineage:}

This lineage includes only two species. Its origin is unknown, and the series apparently ends with the latter species.

Cannartus prismaticus - Ommatartus tetrathalamus Lineage:

The general outline of this lineage has been described previously (Riedel, 1959, p. 292 and text-figure 2), and extends from Cannartus prismaticus through $C$. tubarius, C. violina, C. mammiferus, C. laticonus, Ommatartus antepenultimus and $O$. penultimus to $O$. tetrathalamus. It appears likely that Cannartus (?) petterssoni and Ommatartus hughesi represent a sidebranch from this lineage.

Triactis tripyramis tripyramis - T. tripyramis triangula Lineage:

This lineage also includes only two taxa. It probably originated from a phacodiscid with more than three marginal spines, and is not known to have left any descendants.

Lithocyclia ocellus group - Lithocyclia angustum Lineage (?):

Although the details are not yet known, it seems possible that Lithocyclia angustum developed from a 
member of the L. ocellus group via a member of the L. aristotelis group.

Tristylospyris triceros - Dorcadospyris alata Lineage: Although the evolutionary sequence may be more complicated than suggested earlier (Riedel, 1959, p. 293, and text-figure 3), it appears that Dorcadospyris alata developed from Tristylospyris triceros through the intermediate forms Dorcadospyris ateuchus (and perhaps $D$. papilio), D. forcipata, D. dentata and perhaps D. simplex.

Lamptonium (?) fabaeforme fabaeforme (?) - L. (?) fabaeforme (?) constrictum Lineage:

This lineage also includes only two taxa, and is of uncertain origin.

Theocotyle cryptocephala (?) nigriniae - $T$. venezuelensis Lineage:

The intermediate form in this lineage is Theocotyle cryptocephala cryptocephala (?). T. venezuelensis is. defined very broadly, and apparently left no descendants.

\section{Thyrsocyrtis rhizodon - T. bromia Lineage:}

Two species are included, and the lineage apparently left no descendants.

\section{Thyrsocyrtis triacantha - T. tetracantha Lineage:}

It seems clear that the latter species developed from the former, which may in turn have descended from Thyrsocyrtis hirsuta.

\section{Eusyringium lagena (?) - E. fistuligerum Lineage:}

Only two species are included, and the lineage apparently left no descendants.

Sethochytris babylonis group - S. triconiscus (?) Lineage:

This lineage includes only two species, with clearly transitional intermediate forms. The series apparently became extinct with the latter species.

\section{Lithochytris archaea - L. vespertilio Lineage:}

Although only two species are included, both are defined broadly and may later be split into additional taxa. The lineage apparently terminates with the latter species. The development of Lithochytris vespertilio from $L$. archaea may prove to be a useful biostratigraphic datum, since both forms are robust and $L$. vespertilio at least is widespread. In the assemblages which include $L$. archaea there are a number of other forms with some similarities of structure (thick-walled inflated thorax, and cylindro-conical appendages with characteristically rough surface) which may later prove to be related to this lineage; one of them is illustrated on Plate 10, Figure I.
Cycladophora hispida - C. turris Lineage:

Only two species are included, and no descendants are known.

Stichocorys delmontensis - S. peregrina Lineage (?):

Although no convincing intermediate forms are known, it appears likely that the latter species developed from the former.

Artophormis barbadensis - A. gracilis Lineage:

Only these two species are included.

\section{Podocyrtis papalis - P. ampla Lineage:}

Three broadly defined species are included $(P$. diamesa being the intermediate form), and no descendants are known.

\section{Podocyrtis aphorma - P. goetheana Lineage:}

This lineage commences with Podocyrtis (Podocyrtis) papalis, and proceeds through Podocyrtis aphorma, $P$. sinuosa (?), $P$. mitra and $P$. chalara, to terminate in $P$. goetheana. It thus includes four of the five species ( $P$. trachodes being evidently related but apparently not in the direct line) here assigned to the subgenus Lampterium to separate them from the nominate subgenus ( $P$. papalis - $P$. ampla lineage). The succession in Lampterium is characterized by a decrease in the size of the thorax, an increase in the size of the abdomen and of its pores, and a diminution and ultimately the loss of the feet, with time.

Calocycletta virginis - C. costata Lineage:

Only two species are included, and no descendants are known.

\section{REFERENCES}

Bachmann, Alfred, Papp, Adolf and Stradner, Herbert, 1963. Mikropaläontologische Studien im "Badener Tegel" von Frättingsdorf, N. Ö. Geol. Ges. Wien, Mitt. 56 (1), 117.

Blow, W. H., 1969. Late Middle Eocene to Recent planktonic foraminiferal biostratigraphy. Proc. First Intern. Conf. Planktonic Microfossils. 1.

Bolli, H. M., 1957. Planktonic foraminifera from the Oligocene-Miocene Cipero and Lengua Formations of Trinidad, B.W.I. U.S. Nat. Museum Bull. 215, 97.

1966. Zonation of Cretaceous to Pliocene marine sediments based on planktonic foraminifera. Bol. Asoc. Venezolana Geol. Mineria Petrol. 9 (1), 3.

Bramlette, M. N. and Wilcoxon, J. A., 1967. Middle Tertiary calcareous nannoplankton of the Cipero section, Trinidad, W.I. Tulane Studies Geol. 5 (3), 93. 
Burma, B. H., 1959. On the status of Theocampe Haeckel, and certain similar genera. Micropaleontology. 5 (3), 325.

Bury, P. S., 1862. Figures of remarkable forms of Polycystins, or allied organisms, in the Barbados chalk deposit. 11 p., 25 pl.

Campbell, A. S., 1954. Radiolaria. In Treatise on Invertebrate Paleontology. R. C. Moore (Ed.). (Univ. Kansas Press and Geol. Soc. Am.) Pt. D, Protista 3, 11.

Campbell, A. S. and Clark, B. L., 1944a. Miocene radiolarian faunas from Southern California. Geol. Soc. Am., Spec. Papers. 51.

1944b. Radiolaria from Upper Cretaceous of Middle California. Geol. Soc. Am., Spec. Papers. 57.

Cayeux, Lucien, 1897. Contribution à l'étude micrographique des terrains sédimentaries 1. Étude de quelques dépôts siliceux secondaries et tertiaires du Bassin de Paris et de la Belgique. 2. Craie du Bassin de Paris. Soc. Géol. Nord, Mém. 4 (2).

Clark, B. L. and Campbell, A. S., 1942. Eocene radiolarian faunas from the Mt. Diablo area, California. Geol. Soc. Am., Spec. Papers. 39.

Deflandre, Georges, 1953. Radiolaires fossiles. In Traité de Zoologie. P.-P. Grassé (Ed.). Paris (Masson). 1, 389.

Ehrenberg, C. G., 1838. Über die Bildung der Kreidefelsen und des Kreidemergels durch unsichtbare Organismen. Abhandl, Deut. Akad. Wiss. Berlin. Jahre 1838. 59.

1840. Characteristik von 274 neuen Arten von Infusorien. Über die auffallend rasche Entwicklung dieser Kenntnisse. Ber. Deut. Akad. Wiss. Berlin. Jahre 1840. 197.

1847a. Über eine halibiolithische, von Herrn R. Schomburgk entdeckte, vorherrschend aus mikroskopischen Polycystinen gebildete, Gebirgsmasse von Barbados. Ber. Deut. Akad. Wiss. Berlin. Jahre 1846. 382 .

$1847 \mathrm{~b}$. Über die mikroskopischen kieselschaligen Polycystinen als mächtige Gebirgsmasse von Barbados und über das Verhältniss der aus mehr als 300 Neuen Arten bestehenden ganz eigenthümlichen Formengruppe jener Felsmasse zu den jetzt lebenden Thieren und zur Kreidebildung. Eine neue Anregung zur Erforschung des Erdlebens. Ber. Deut. Akad. Wiss. Berlin. Jahre 1847. 40.

1854. Mikrogeologie. Leipzig (Voss) Fortsetzung (1856).

1858. Kurze Characteristik der 9 neuen Genera und der 105 neuen Species des ägäischen Meeres und des Tiefgrundes des Mittel-Meeres. Monatsber. Deut. Akad. Wiss. Berlin. Jahre 1858. 10.

1860. Über den Tiefgründ des stillen Oceans zwischen Californien und den Sandwich-Inseln aus bis $15600^{\prime}$ Tiefe nach Lieut. Brooke. Monatsber. Deut. Akad. Wiss. Berlin. Jahre 1860. 819.
Ehrenberg, C. G., 1861. Über die Tiefgrund-Verhältnisse des Oceans am Eingange der Davisstrasse und bei Island. Monatsber. Deut. Akad. Wiss. Berlin. Jahre 1861. 275.

1872a. Mikrogeologischen Studien als Zusammenfassung der Beobachtungen des kleinsten Lebens der Meeres Tiefgründe aller Zonen und dessen geologischen Einfluss. Monatsber. Deut. Akad. Wiss. Berlin. Jahre 1872. 265.

$1872 \mathrm{~b}$. Mikrogeologische Studien über das kleinste Leben der Meeres-Tiefgründe aller Zonen und dessen geologischen Einfluss. Abhandl. Deut. Akad. Wiss. Berlin. Jahre 1872. 131.

1873. Grossere Felsproben des PolycystinenMergels von Barbados mit weiteren Erläuterungen. Ber. Deut. Akad. Wiss. Berlin. Jahre 1873. 213.

1875. Fortsetzung der mikrogeologischen Studien als Gesammt-Uebersicht der microskopischen Paläontologie gleichartig analysirter Gebirgsarten der Erde, mit specieller Rücksicht auf den Polycystinen-Mergel von Barbados. Abhandl. Deut. Akad. Wiss. Berlin. Jahre 1875. 1.

Foreman, H. P., 1966. Two Cretaceous radiolarian genera. Micropaleontology. 12 (3), 355.

1968. Upper Maestrichtian Radiolaria of California. Spec. Papers Palaeontol. (Palaeontol. Assoc., London). 3.

Frizzell, D. L. and Middour, E. S., 1951. Paleocene Radiolaria from Southeastern Missouri. Missouri Univ. School Mines Met., Bull., Tech. Ser. (77), 1.

Goll, R. M., 1969. Classification and phylogeny of Cenozoic Trissocyclidae (Radiolaria) in the Pacific and Caribbean Basins. Part II. J. Paleontol. 43 (2), 322.

Haeckel, Ernst, 1862. Die Radiolarien. (Rhizopoda Radiaria). Berlin, (Reimer).

1881. Entwurf eines Radiolarien-Systems auf Grund von Studien der Challenger-Radiolarien. Jena Z. Med. Naturwiss. 15 (3), 418.

1887. Report on the Radiolaria collected by H.M.S. Challenger during the years 1873-76. Rept. Voyage Challenger, Zool. 18.

Hay, W. W., Mohler, H. P., Roth, P. H., Schmidt, R. R. and Boudreaux, J. E., 1967. Calcareous nannoplankton zonation of the Cenozoic of the Gulf Coast and Caribbean-Antillean area, and transoceanic correlation. Trans. Gulf Coast Assoc. Geol. Soc. 17, 428.

Hinde, G. J., 1890. Notes on Radiolaria from the Lower Paleozoic rocks (Llandeilo-Caradoc) of the South of Scotland. Ann. Mag. Natur. Hist. 6 (31), 40.

Kozlova, G. E. and Gorbovets, A. N., 1966. Radiolyarii verkhnemelovykh i verkhneeotsenovykh otlozhenii Zapadno-Sibirskoi Nizmennosti. Tr. Vses. Neft. Nauchn.-Issled. Geologorazved.Inst. (VNIGRI), 248, 159 p.

Krasheninnikov, V. A., 1960. Nekotorye Radiolyarii Nizhnego i Srednego Eotsena Zapadnogo Predkavkazya. Min. Geol. i Okhr. Nedr SSSR Vses. Nauchn.Issled. Geol. Neft. Inst. 16, 271. 
Lipman, R. Kh., 1960. Radiolaria. In Stratigrafiya i fauna melovykh otlozhenii zapadno-sibirskoi nizmennosti. Min. Geol. SSSR, Tr. Vses. Nauchn.-Issled. Geol. Inst. (VSEGEI), new series, 29, 124.

Lucchese, Caterina, 1927. Radiolari miocenini di Salsomaggiore. Giorn. Geol. Bologna. 2 (2), 80.

Martin, G. G., 1904. Radiolaria. Maryland Geol. Surv. (Miocene). 447.

Müller, Johannes, 1855. Über die im Hafen von Messina beobachteten Polycystinen. Ber. Deut. Akad. Wiss. Berlin. Jahre 1855. 671 .

1858. Über die Thalassicollen, Polycystinen und Acanthometren des Mittelmeeres. Abhandl. Deut. Akad. Wiss. Berlin. Jahre 1858. 1.

Nakaseko, Kojiro, 1955. Miocene Radiolarian fossil assemblage from the Southern Tojama Prefecture in Japan. Osaka Univ. Sci. Rep. 4, 65.

1963. Neogene Cyrtoidea (Radiolaria) from the Isozaki Formation in Ibaraki Prefecture, Japan. Osaka Univ. Sci. Rep. 12 (2), 165.

Nakaseko, Kojiro and Chiji, Manzo., 1964. Discovery of radiolarian fossils from the Osaka Group. Osaka Museum Natur. Hist., Bull. 17, 87.

Nigrini, Catherine, 1967. Radiolaria in pelagic sediments from the Indian and Atlantic Oceans. Scripps Inst. Oceanog., Bull. 11.

Parker, F. L., 1967. Late Tertiary biostratigraphy (planktonic foraminifera) of tropical Indo-Pacific deep-sea cores. Bull. Am. Paleontol. 52 (235), 111.

Pessagno, E. A., Jr., 1963. Upper Cretaceous Radiolaria from Puerto Rico. Micropaleontology. 9 (2), 197.

Principi, Paolo, 1909. Contributo allo studio dei Radiolari Miocenici Italiani. Boll. Soc. Geol. Ital. 28, 1.

Riedel, W. R., 1952. Tertiary Radiolaria in Western Pacific sediments. Göteborgs $\mathrm{Kgl}$. Vetensk.-och Vitterhets-Samhallës Handl. följ 7, ser. B, 6 (3), 1.

1953. Mesozoic and Late Tertiary Radiolaria of Rotti. J. Paleontol. 27 (6), 805.

1957a. Radiolaria: a preliminary stratigraphy. Rept. Swed. Deep-Sea Exped. 6 (3), 59.

1957b. Eocene Radiolaria. U.S. Geol. Surv. Profess. Paper. 280G, 257.

1959. Oligocene and Lower Miocene Radiolaria in tropical Pacific sediments. Micropaleontology. 5 (3), 285.

1967a. Some new families of Radiolaria. Geol. Soc. London, Proc. (1640), 148.

1967b. Subclass Radiolaria. In The Fossil Record. W. B. Harland et al. (Eds.). London (Geol. Soc. London).
Riedel, W. R., (in press) a. Systematic classification of polycystine Radiolaria. In The Micropalaeontology of Oceans. B. M. Funnell and W. R. Riedel (Ed.). Cambridge (Cambridge Univ. Press).

(in press) b. Occurrence of pre-Quaternary Radiolaria in deep-sea sediments. In The Micropalaeontology of Oceans. B. M. Funnell and W. R. Riedel (Eds.). Cambridge (Cambridge Univ. Press).

Riedel, W. R. and Foreman, H. P., 1961. Type specimens of North American Paleozoic Radiolaria. $J$. Paleontol. 35 (3), 628.

Riedel, W. R. and Funnell, B. M., 1964. Tertiary sediment cores and microfossils from the Pacific Ocean floor. Quart. J. Geol. Soc. London. 120, 305.

Rüst, David, 1885. Beiträge zur Kenntniss der fossilen Radiolarien aus Gesteinen des Jura. Palaeontographica. 31, ser. 3, 273.

1888. Beiträge zur Kenntniss der fossilen Radiolarien aus Gesteinen der Kreide. Palaeontographica. 34, 181.

1892. Radiolaria from the Pierre Formation of North-Western Manitoba. Geol. Natur. Hist. Surv. Can., Contrib. Can. Micropalaeontol. 101.

Squinabol, Senofonte, 1914. Contributo alla conoscenza dei Radiolarii fossili del Veneto. Appendice: Di un genere di Radiolari caratteristico del Secondario. 1st Geol. Univ. Padova, Mem. 2, 249.

Stöhr, Emil, 1880. Die Radiolarienfauna der Tripoli von Grotte Provinz Girgenti in Sicilien. Palaeontographica. 26 (ser. 3, vol. 2), 71.

Strelkov, A. A. and Lipman, R. Kh., 1959. Podklass Radiolaria. Sistematicheskaya Chast. In Osnovy Paleontologii. Yu. A. Orlov (Ed.). Moscow (Izdatelstvo Akad. Nauk SSSR).

Sutton, H. J., 1896a. Radiolaria: A new genus from Barbados. Am. Mon. Microsc. J. 17 (194), 61.

1896b. Radiolaria: A new genus from Barbados. Am. Mon. Microsc. J. 17 (196), 138.

Tan Sin Hok, 1927. Over de samenstelling en het onstaan van krijten margelgesteenten van de Molukken. Verhandl. Mijnwezen Ned. Oost Indie, jaarg. 1926. 3,5 .

Vinassa de Regny, P. E., 1900. Radiolari Miocenici Italiani. Reale Accad. Sci. 1st Bologna, Mem. Ser. 5, 8,565 .

Wetzel, O., 1935. Die Mikropalaeontologie des Heiligenhafener Kieseltones (Ober-Eozän). Niedersaechs. Geol. Verhandl. Jahresber. 27, 41.

Zittel, K. A., 1876. Ueber einige fossile Radiolarien aus der norddeutschen Kreide. Z. Deut. Geol. Ges. 28, 75 . 


\section{EXPLANATION OF PLATES}

On the following plates, all figures are at a magnification of $\times 225$ unless otherwise specified.

The U. S. National Museum catalog numbers (from catalog 35) following each figure identification and its locality indicate the slide on which the illustrated specimen is to be found. These specimen locations following the USNM numbers are given in terms of "England Finder" coordinates (see Riedel and Foreman, 1961). The England Finder is always used with its label at the microscopist's left hand, and the RHS and LHS in the notations indicate whether the label of the specimen slide was on the right-hand side or left-hand side, respectively.
Figures are arranged in approximately systematic order in four groups-Cretaceous, middle Eocene, late Eocene and Oligocene, and Miocene. Illustrations of some members of the two last-mentioned groups are taken from well-preserved assemblages from Caribbean localities and deep-sea cores, since some of the species are not widely familiar and could not be effectively illustrated from the less well preserved material in the drill-cores.

On the plates of middle Eocene forms, groups of illustrations showing intraspecific variation are bracketed together, and arrows are used to show lines of evolutionary development. 

PLATE 1

Cretaceous Radiolaria

Figure 1 Actinommid, gen. et sp. indet. 24A-1-1. Dark; USNM 167256; A 30/3; LHS.

Figure 2 Saturnalin aff. Saturnalis minimus. 24A-1-1. Dark; USNM 167257; S 25/0; LHS.

Figure 3 Saturnalin, gen. et sp. indet. 24A-1-1. Dark; USNM 167258; Q 45/0; LHS.

Figures 4\&5 Amphibrachium cf. A. ornatum. 24A-1-1. 4: Dark; USNM 167256; S 22/0; LHS.

5: Dark; USNM 167259; C 49/2; RHS.

Figures 6\&7 Amphibrachium cf. A. concentricum. 24A-1-1. 6: Dark; USNM 167259; T 35/0; RHS.

7: Dark; USNM 167258; L 43/3; LHS.

Figures 8\&9 Spongodiscids, genn. et spp. indet. 24A-1-1.

8: Dark; USNM 167256; D 40/4; LHS

9: USNM 167260; E 55/0; RHS. 

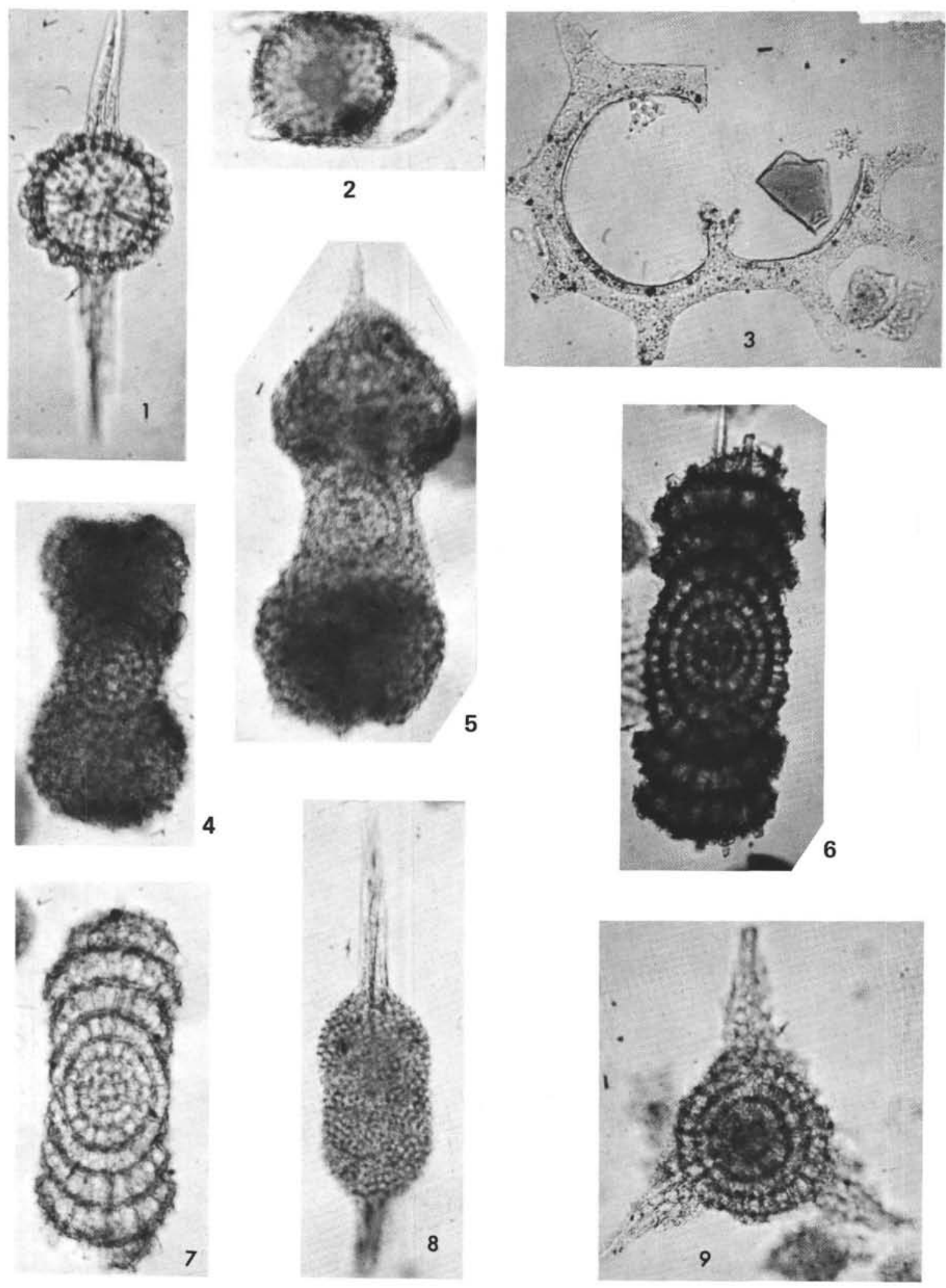

Plate 1. 
PLATE 2

Cretaceous Radiolaria

Figure 1 Spongodiscid cf. Septinastrum dogeli. 24A-1-1.

Dark; USNM 167256; W 18/0; LHS.

Figure 2 Spongopyle insolita. 24A-4-2, $20-22 \mathrm{~cm}$. USNM 167261; Z 14/2; LHS.

Figure 3 Euchitonia triradiata (?). 24A-4-2, 20-22 cm.

USNM 167261; S 29/3; LHS

Figure 4 Spongodiscid, gen. et sp. indet. 24A-4-2, 20-22 cm. USNM 167262; B 57/1; LHS.

Figure $5 \quad$ Pseudoaulophacus gallowayi (?). 24A-1-1.

Dark; USNM 167257; T 25/3; LHS.

Figures 6\&7 Pseudoaulophacids (?), genn. et spp. indet. 24A-1-1.

$\times 150$.

6: USNM 167258; P 27/3; LHS.

7: USNM 167257; A 14/4; LHS. 

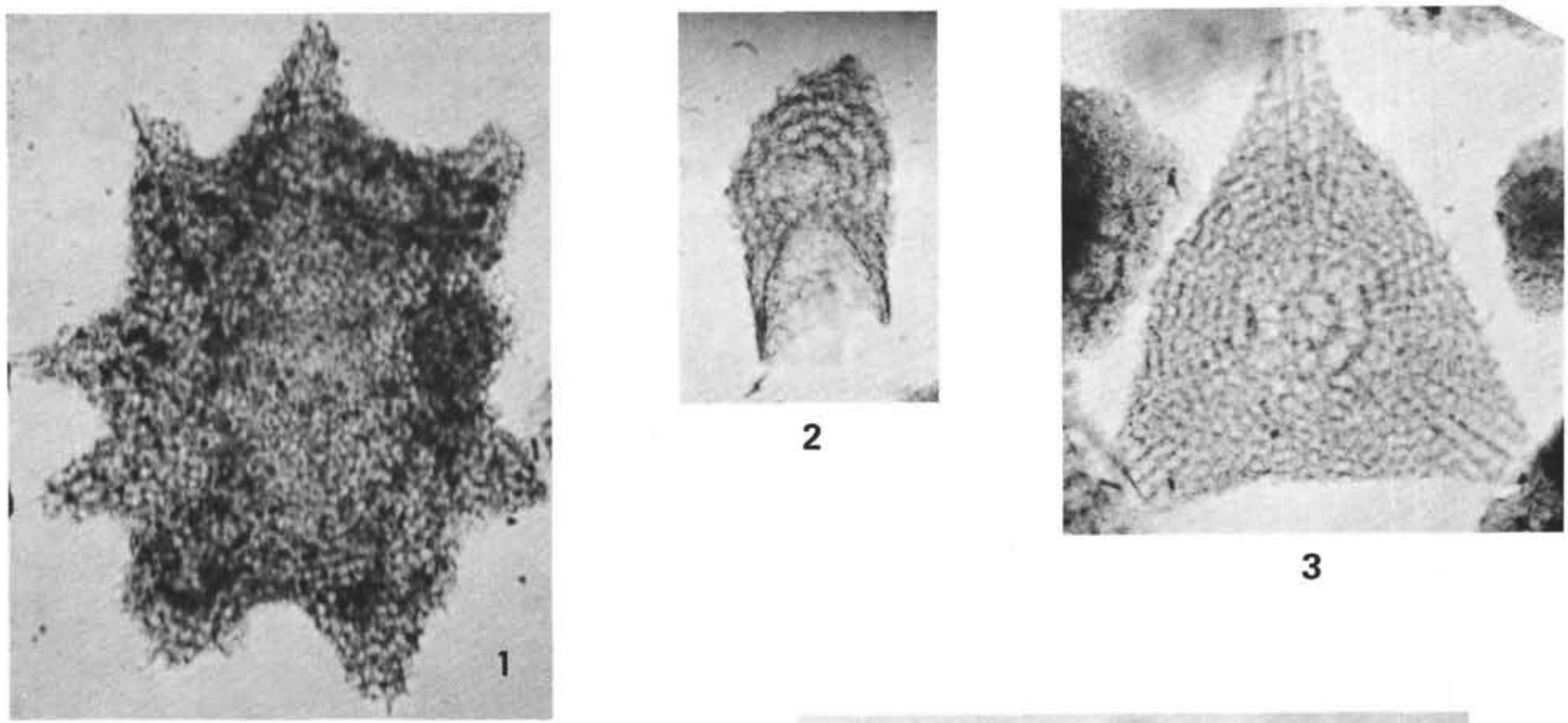

3
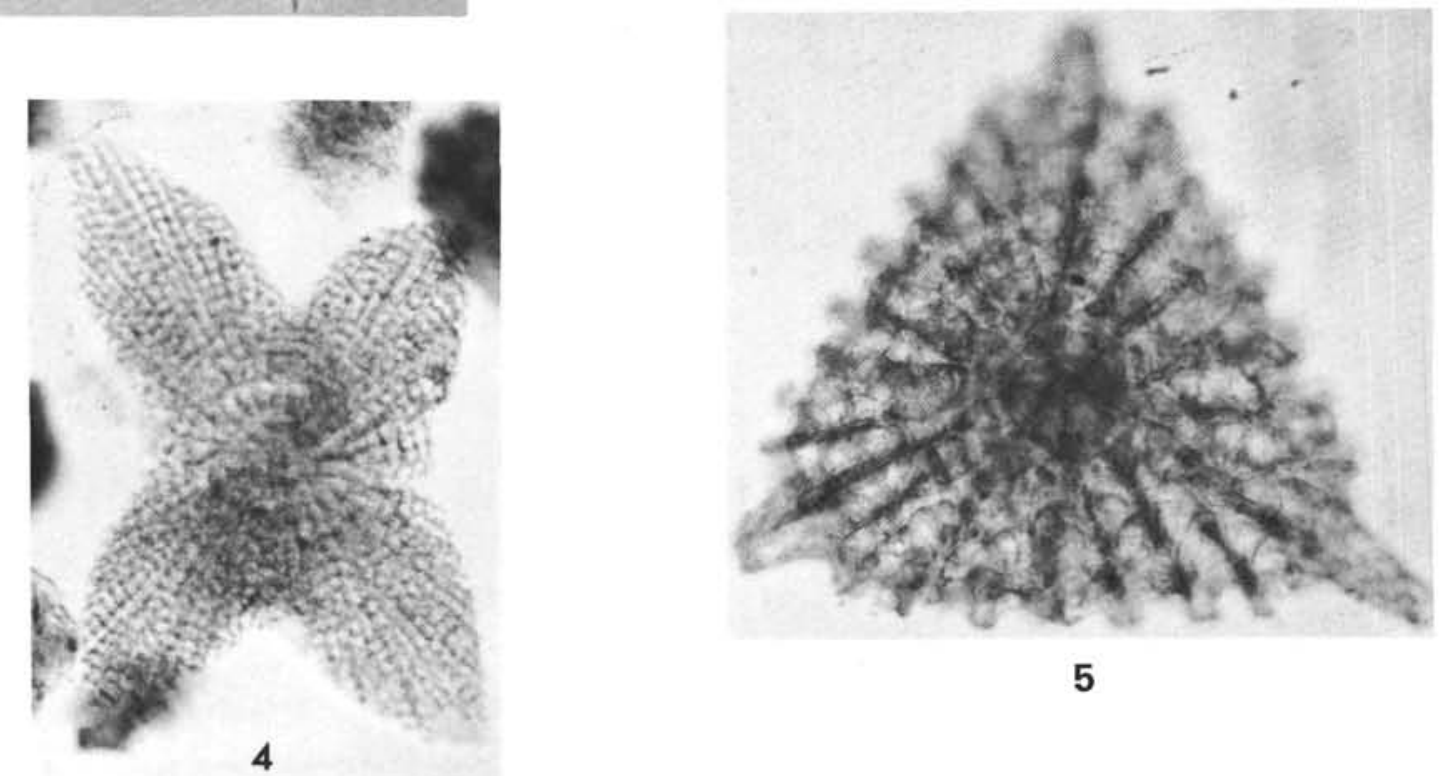

5
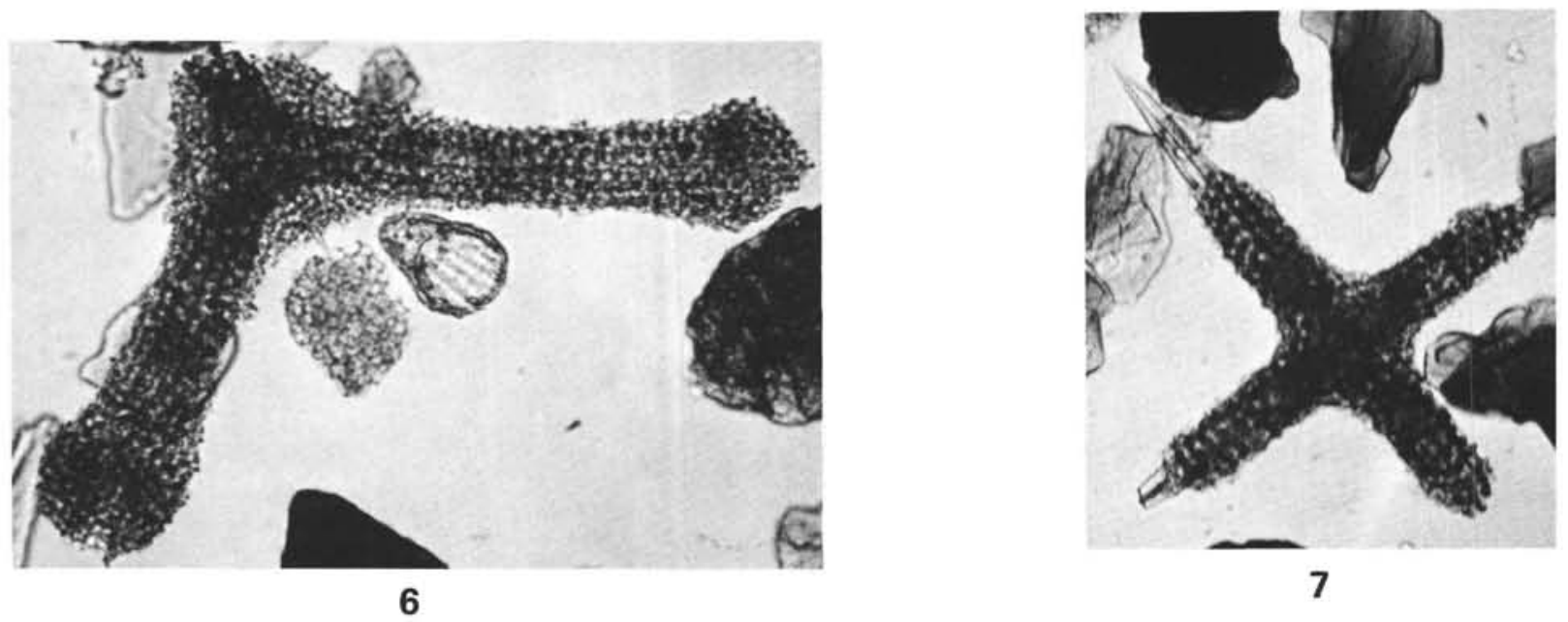

Plate 2. 
PLATE 3

Cretaceous Radiolaria

Figure 1 Theocapsomma sp. 24A-1-1

Dark; USNM 167257; M 52/0; RHS.

Figure 2 Dicolocapsa verbeeki (?) 24A-1-1.

Dark; USNM 167259; G 30/1; RHS. The specimen is oblique, the cephalis (in the lower part of the illustration) being on the side of the specimen toward the observer, and the mouth opposite.

Figure 3 Cornutella sp. 24A-1-1.

Dark; USNM 167263; W 26/1; LHS.

Figures $4 \& 5$ Theoperids, genn. et sp. indet. 24A-1-1.

4: Dark; USNM 167259; X 33/0; RHS.

5: Dark; USNM 167256; M 53/0; RHS.

Figures 6\&7 Theoperids cf. Sciadiocapsa. 24A-1-1.

6: USNM 167256; N 20/3; LHS.

7: USNM 167259; P 31/0; LHS.

Figures 8,9\&10 Dictyomitra spp. 24A-1-1.

8: USNM 167259; W 34/2; LHS.

9: USNM 167256; D 43/1; LHS.

10: USNM 167259; S 40/0; LHS.

Figure 11 Amphipyndax sp. 24A-1-1.

Dark; USNM 167256; G 10/0; LHS.

Figure 12 Theocampe sp. 24A-1-1.

Dark; USNM 167256; G 36/2; RHS.

Figure 13 Artostrobiid, gen. et sp. indet. 24A-4-2, 20-22 cm.

USNM 167264; M 44/4; LHS. 

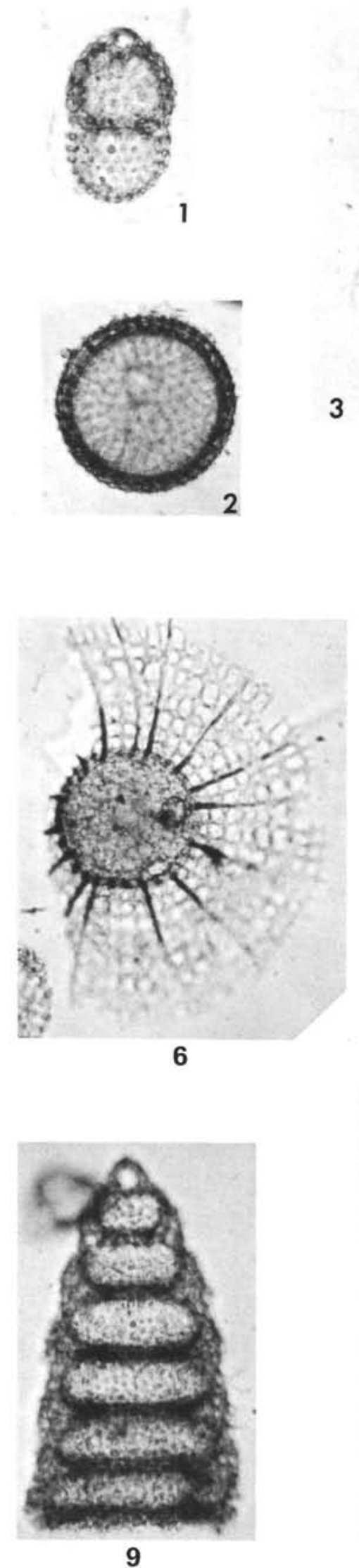
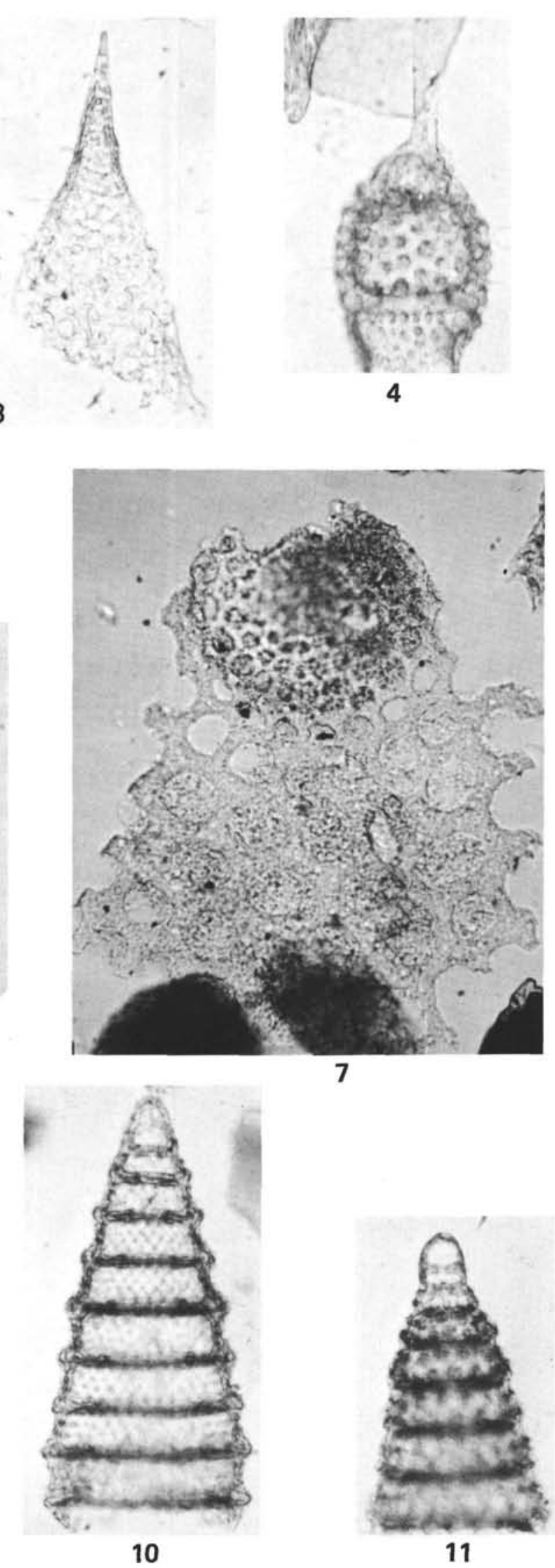

Plate 3.

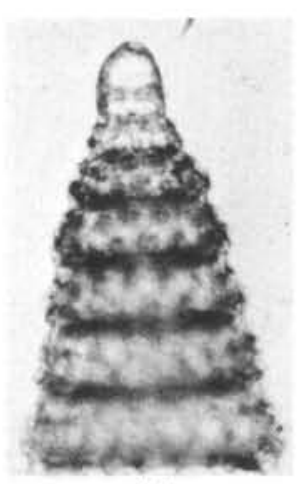

11
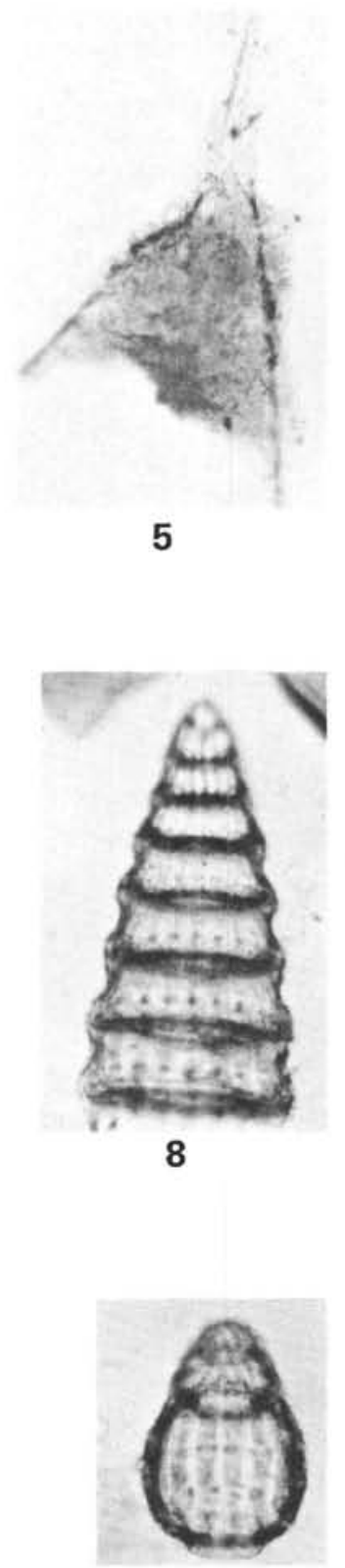

12

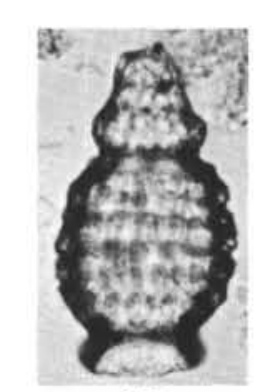

13

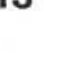




\section{PLATE 4}

Middle Eocene Radiolaria

Figure 1 Spongatractus pachystylus. $29-10-1,78-80 \mathrm{~cm}$. USNM 167265; B 29/0; RHS.

Figure 2 Lithapium (?) plegmacantha. $29-12-3,100-102 \mathrm{~cm}$. USNM 167266; R 11/4; RHS. Holotype.

Figure 3 Lithapium (?) plegmacantha. 29B-10-2, 100-102 cm. USNM 167267; X 26/1; RHS.

Figure 4 Lithapium (?) anoectum. 29-10-5, 120-122 cm. USNM 167268; H 54/4; LHS.

Figure 5 Lithapium (?) anoectum. 29-14-4, 102-104 cm. USNM 167269; T 54/1; RHS. Holotype.

Figure $6 \quad$ Lithapium (?) mitra (?). 29-9-6, $72-74 \mathrm{~cm} . \times 150$. USNM 167270; W 58/0; RHS.

Figure $7 \quad$ Lithapium (?) mitra (?). 29-9-5, $112-114 \mathrm{~cm} . \times 150$. USNM 167271; U 38/1; LHS.

Figure 8 Triactis tripyramis tripyramis. 29B-10-4, $24-26 \mathrm{~cm}$. USNM 167272; L 45/2; RHS.

Figure 9 Triactis tripyramis triangula. 29B-9-5, $83-85 \mathrm{~cm}$. USNM 167273; F 15/0; LHS.

Figure 10

Triactis tripyramis triangula. 29B-10-2, 100-102 cm. USNM 167267; F 44/1; RHS. 


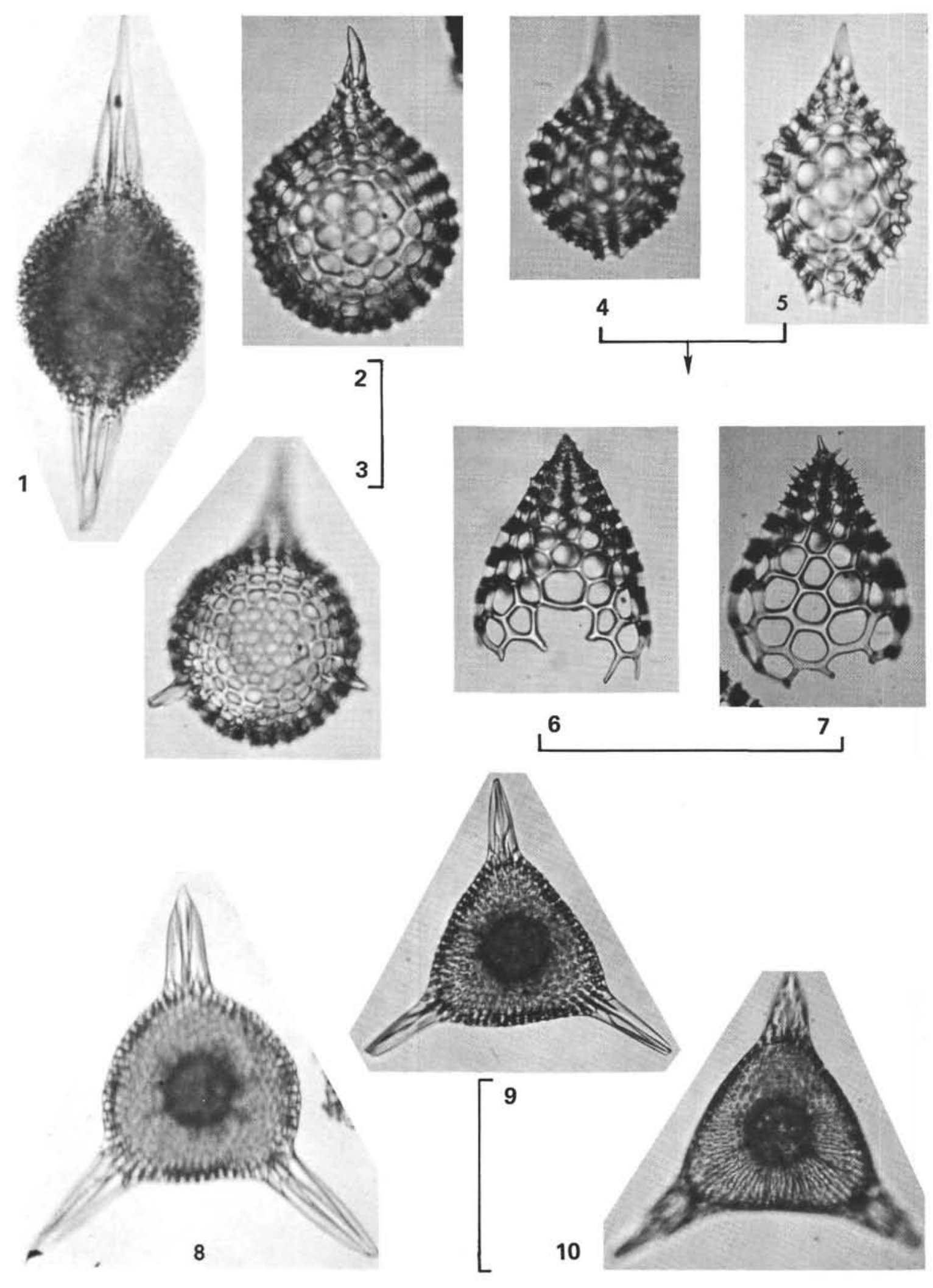

Plate 4. 


\section{PLATE 5}

Middle Eocene Radiolaria

Figure 1 Lithocyclia ocellus group. 29-10-1, 78-80 cm. USNM 167265; R 30/0; RHS.

Figure 2 Lithocyclia ocellus group. 29B-8-4, 111-113 cm. USNM 167274; J 37/0; RHS.

Figure 3 Giraffospyris didiceros group. 29B-9-2, 17-19 cm. USNM 167275; O 38/0; RHS.

Figure $4 \quad$ Giraffospyris didiceros group. 29-12-3, 100-102 cm. USNM 167276; W 17/0; LHS.

Figure 5 Giraffospyris didiceros group. 29-9-6, 8-10 cm. USNM 167277; M 26/1; RHS.

Figure 6 Lamptonium (?) fabaeforme fabaeforme (?). 29B-10-2, $100-102 \mathrm{~cm}$.

USNM 167267; P 51/4; RHS.

Figure $7 \quad$ Lamptonium (?) fabaeforme (?) constrictum. 29B-9-5, 83-85 cm.

USNM 167278; J 39/0; RHS. Holotype.

Figures 8\&9 Lamptonium (?) fabaeforme (?) chaunothorax. 29B-10-2, 100-102 cm.

8: USNM 167267; Y 43/0; RHS.

9: USNM 167267; S 18/3; LHS. Holotype. 

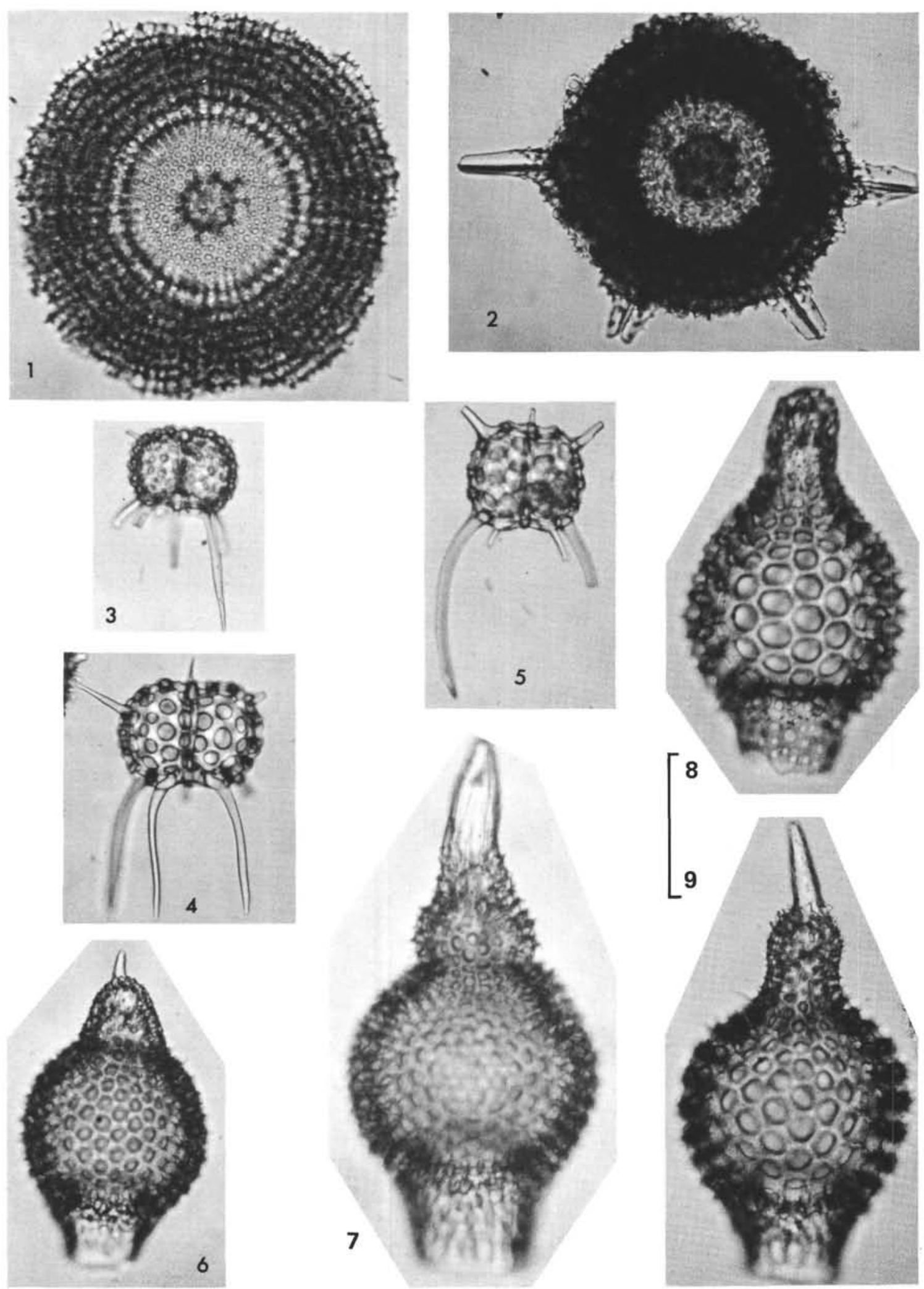

Plate 5. 


\section{PLATE 6}

Middle Eocene Radiolaria

Figure 1 Calocycloma (?) ampulla. 29-16-1, 116-118 cm. USNM 167279; W 29/2; RHS.

Figure 2 Anthocyrtoma sp. 29B-9-5, $83-85 \mathrm{~cm}$. USNM 167280; M 36/0; LHS.

Figures 3\&4 Anthocyrtoma sp. 29-9-5, 112-114 cm.

3: USNM 167271; H 42/4; RHS.

4: USNM 167271; L 15/3; LHS.

Figures 5\&6 Theocotyle cryptocephala (?) nigriniae. 29B-10-3, 10-12 cm.

5: USNM 167281; W 47/2; RHS.

6: USNM 167282; S 54/0; RHS.

Figures 7\&8 Theocotyle cryptocephala cryptocephala (?). 29B-10-2, 100-102 cm.

7: USNM 167283; K 18/4; LHS.

8: USNM 167267; K 54/3; RHS.

Figures 9\&10 Theocotyle venezuelensis. 29B-10-2, 100-102 cm. 9: USNM 167267; D 55/4; RHS.

10: USNM 167267; D 26/0; RHS. Holotype. 

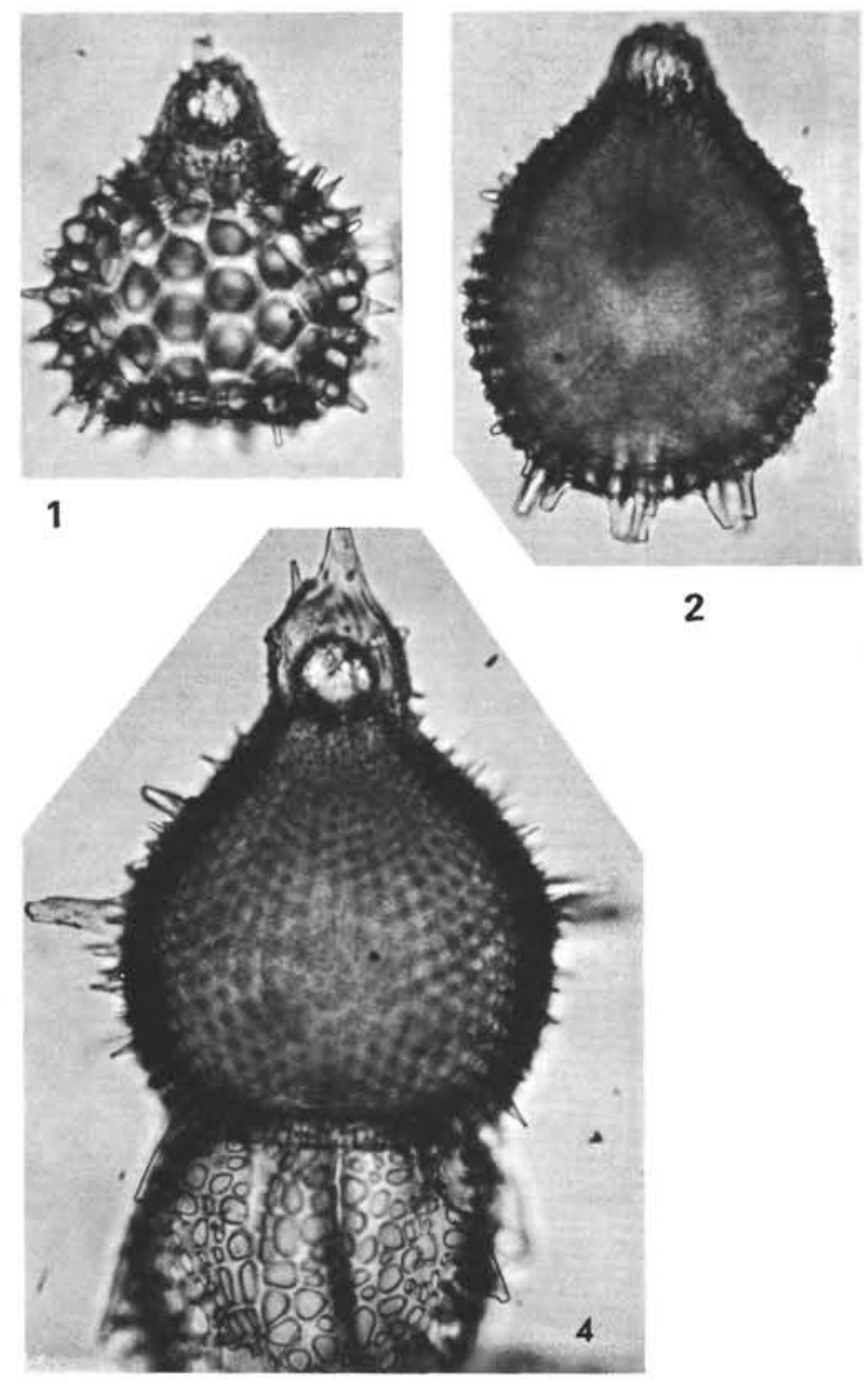

2
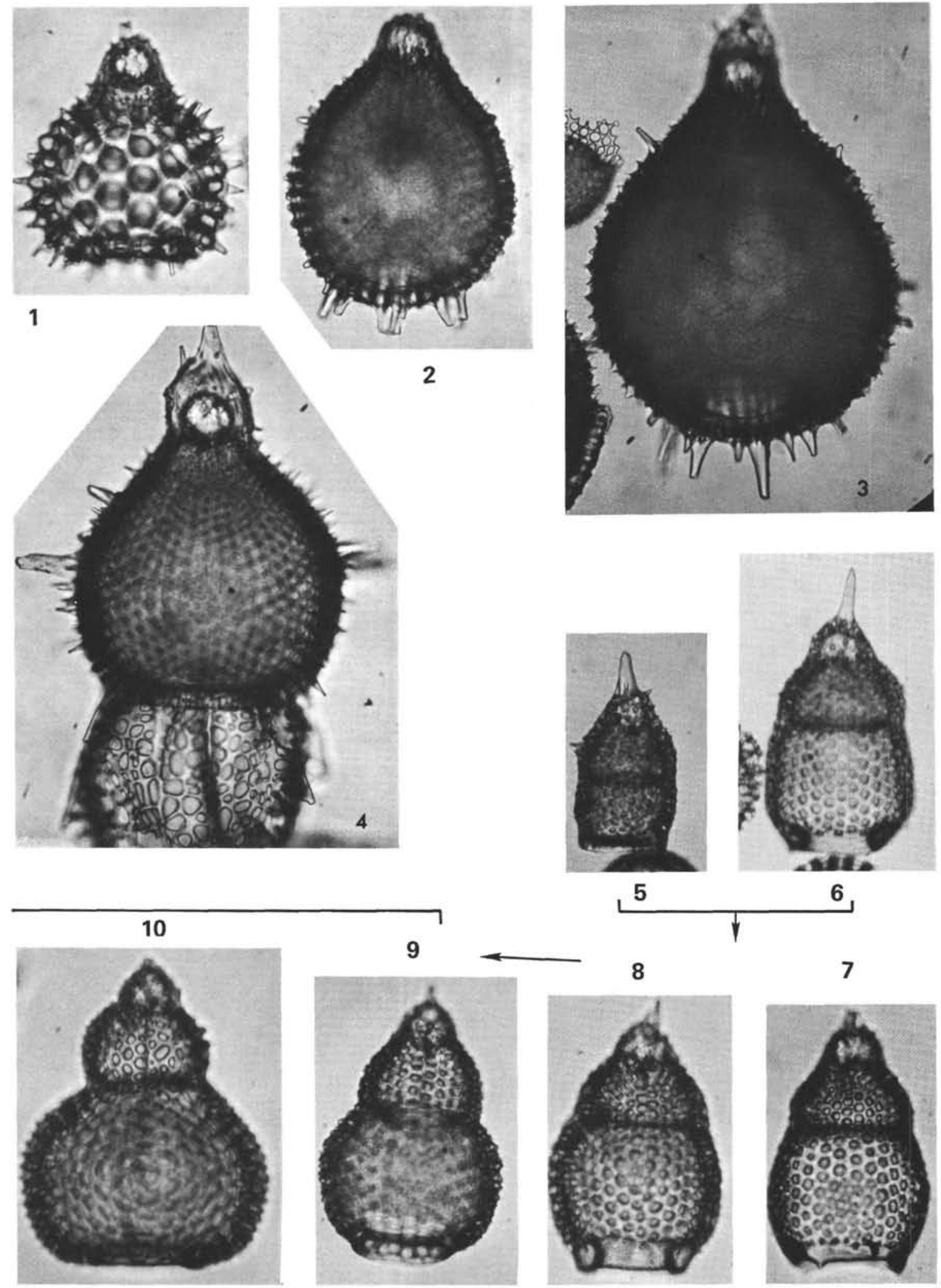

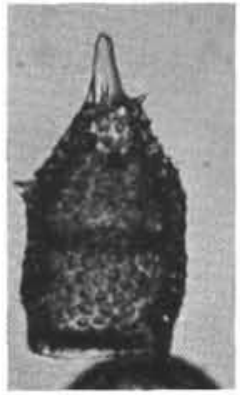

5

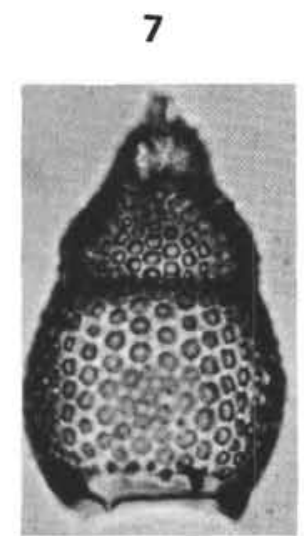

Plate 6. 
PLATE 7

Middle Eocene Radiolaria

Figures 1\&2 Theocotyle venezuelensis. 29-16-1, 116-118 cm.

1: USNM 167284; R 43/1; RHS.

2: USNM 167285 ; M 35/0; RHS.

Figure 3 Theocotyle (?) ficus. 29B-10-2, 100-102 cm. USNM 167286 ; $\mathrm{S} 30 / 0$; RHS.

Figure 4 Theocotyle (?) ficus. 29B-9-5, $83-85 \mathrm{~cm}$. USNM 167278; M 43/2; RHS.

Figure 5 Theocotyle (?) ficus. 29-9-5, 112-114 cm. USNM 167271; W 42/0; RHS.

Figures 6\&7 Thyrsocyrtis rhizodon. 29-9-6, 72-74 cm. 6: USNM 167287; T 31/1; RHS.

7: USNM 167287; S 50/1; LHS.

Figures 8\&9 Thyrsocyrtis hirsuta hirsuta. 29B-10-4, 24-26 cm. 8: USNM 167288; T 29/1; RHS.

9: USNM 167289; F 54/0; RHS. 


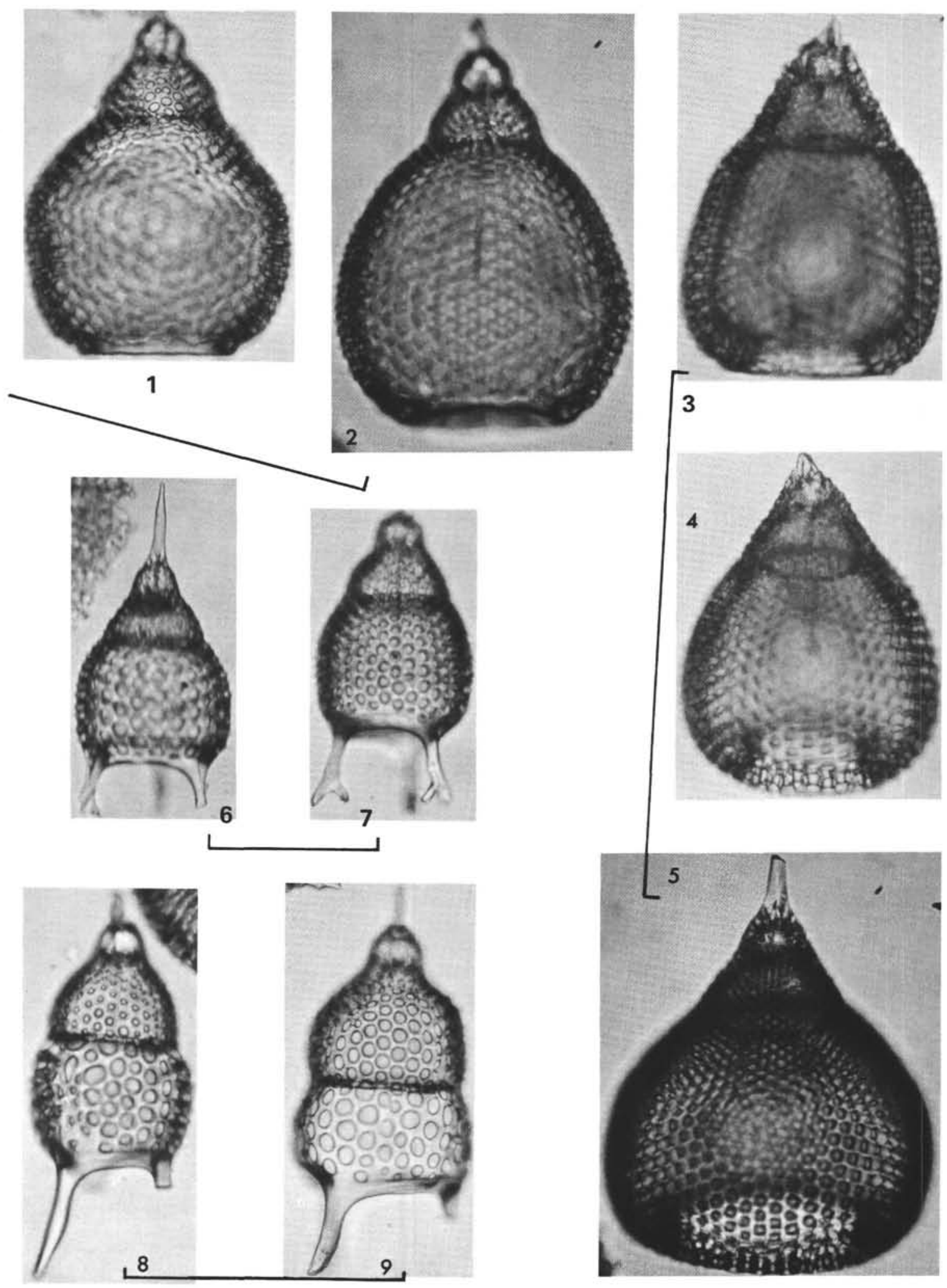

Plate 7. 


\section{PLATE 8}

Middle Eocene Radiolaria

Figure 1 Thyrsocyrtis hirsuta robusta. 29B-9-5, 83-85 cm. USNM 167290; V 56/4; RHS. Holotype.

Figure 2 Thyrsocyrtis triacantha. 29-10-1, 78-80 cm. USNM 167265 ; M 33/0; RHS.

Figure 3 Thyrsocyrtis triacantha. 29-9-6, $72-74 \mathrm{~cm}$. USNM 167287; M 26/2; RHS.

Figure $4 \quad$ Gen. et sp. indet. 29-9-5, 112-114 cm. USNM 167294; P 35/0; RHS.

Figure 5 Eusyringium lagena (?). 29-10-5, 120-122 cm. USNM 167291; R 36/1; LHS.

Figure $6 \quad$ Eusyringium lagena (?). 29-16-1, 116-118 cm. USNM 167279; N 25/4; LHS.

Figure $7 \quad$ Eusyringium lagena (?). 29-14-5, 37-39 cm. USNM 167292; H 46/0; RHS.

Figures 8\&9 Eusyringium fistuligerum. 29-10-5, 120-122 cm. 8: USNM 167293; K 16/2; LHS.

9: USNM 167268; M 50/1; LHS.

Figure $10 \quad$ Gen. et sp. indet. 29-9-5, 112-114 cm. USNM 167271; B 17/0; LHS. 

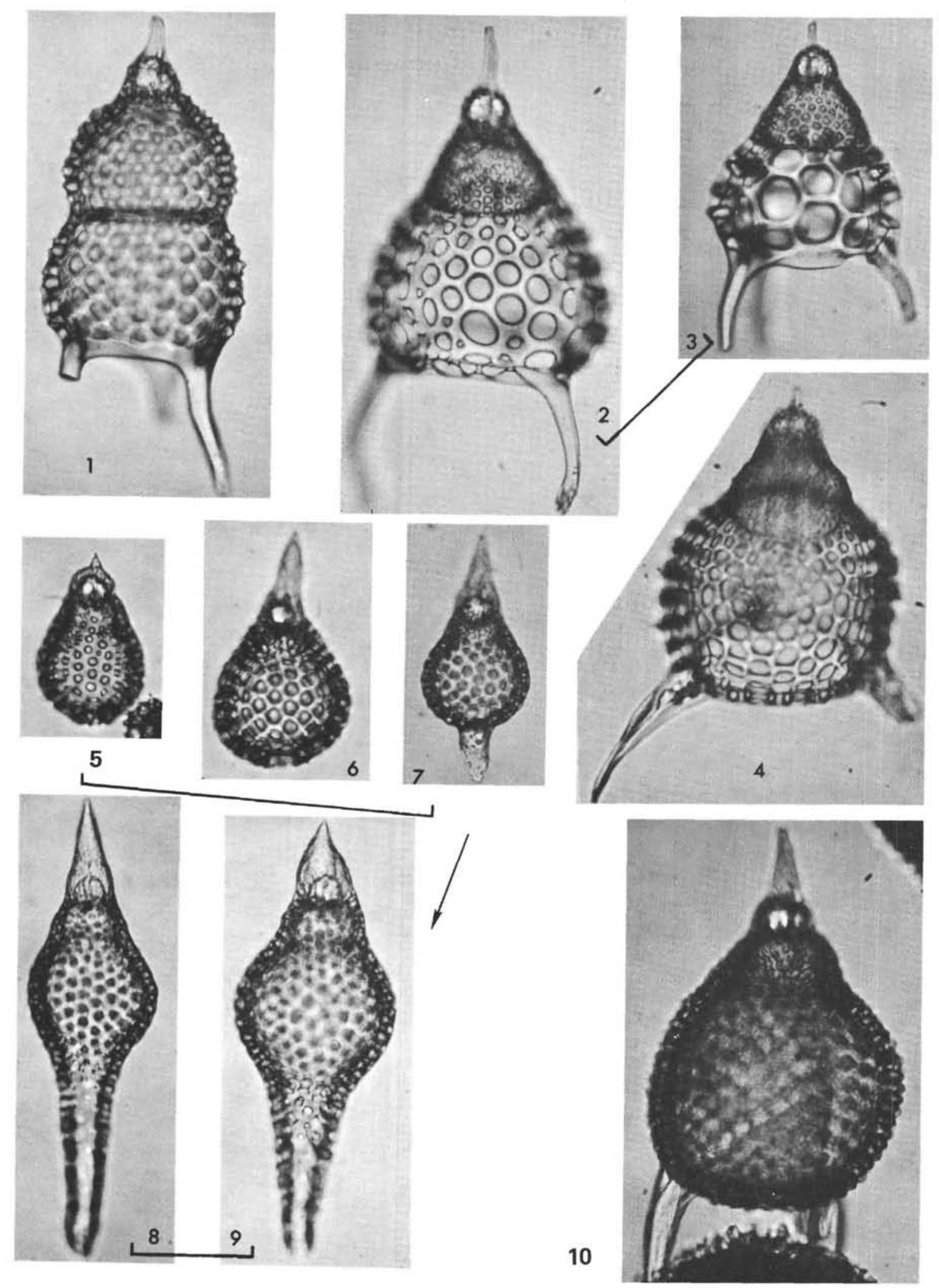

Plate 8. 


\section{PLATE 9}

Middle Eocene Radiolaria

Figure 1

Figure 2

Figure 3

Figure 4

Figure 5

Figure 6

Figure 7

Figure 8

Figure 9
Sethochytris babylonis group. 29-10-5, 120-122 cm. USNM 167293 R 45/2; LHS.

Sethochytris babylonis group. 29-9-3, 70-72 cm. USNM 167295; J 46/0; RHS.

Sethochytris babylonis group. 29-16-1, 116-118 cm. USNM 167296; G 45/0; LHS.

Gen. et sp. indet. 29-10-2, 99-101 cm. USNM 167297; D 29/0; RHS.

Gen. et sp. indet. 29-9-6, 72-74 cm. USNM 167287; B 32/1; RHS.

Sethochytris triconiscus (?). 29-9-6, 8-10 cm. USNM 167277; M 43/4; RHS.

Lithochytris archaea. 29B-10-4, 24-26 cm. USNM 167289; B 30/0; RHS. Holotype.

Lithochytris vespertilio. 29-16-1, 116-118 cm. USNM 167284; T 46/3; LHS.

Lithochytris vespertilio. $29-10-1,78-80 \mathrm{~cm}$. USNM 167265; E 41/1; RHS. 

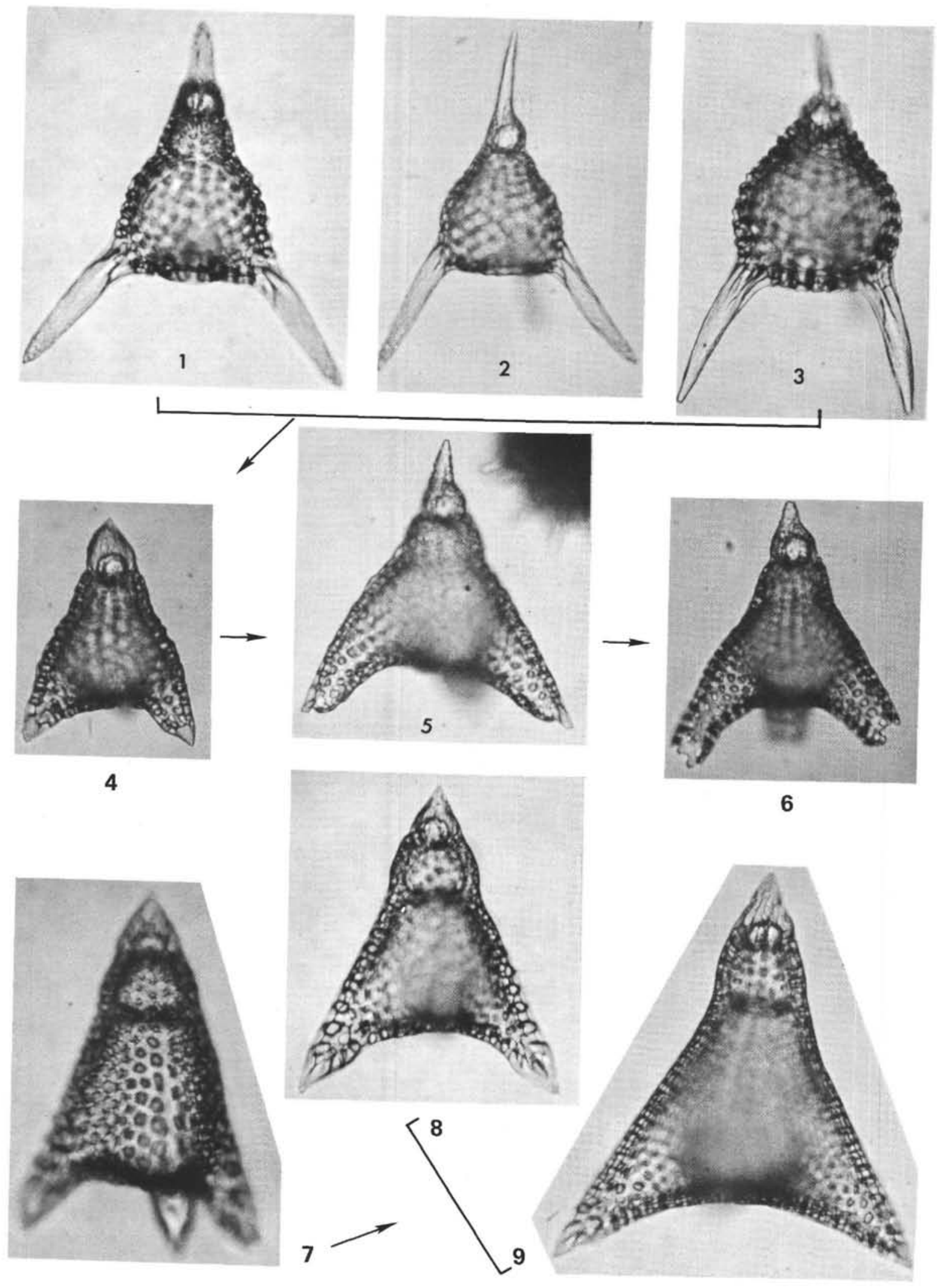

Plate 9. 
PLATE 10

Middle Eocene Radiolaria

Figure 1 Gen. et sp. indet. 29B-10-4, 24-26 cm. USNM 167298; Q 15/0; LHS.

Figures 2\&3 Theocorys anaclasta. 29B-9-5, 83-85 cm. 2: USNM 167299; E 37/4; LHS. Holotype. 3: USNM 167299; H 11/0; LHS.

Figure 4 Theocorys anapographa. 29-14-4, 102-104 cm. USNM 167300; J 46/1; RHS. Holotype.

Figure $5 \quad$ Lychnocanium bellum. 29-16-1, 116-118 cm. USNM 167301; H 38/3; RHS.

Figure 6 Dictyophimus craticula. 29-10-4, 100-102 cm. X 150. USNM 167302; F 29/2; RHS.

Figure 7 Phormocyrtis striata. 29B-10-2, 100-102 cm. USNM 167267; T 40/0; RHS.

Figure $8 \quad$ Lithocampium sp. 29-16-2, 90-92 cm. USNM 167303; O 52/3; RHS.

Figure 9 Cycladophora hispida. 29-9-6, 72-74 cm. USNM 167287; S 49/4; LHS. 


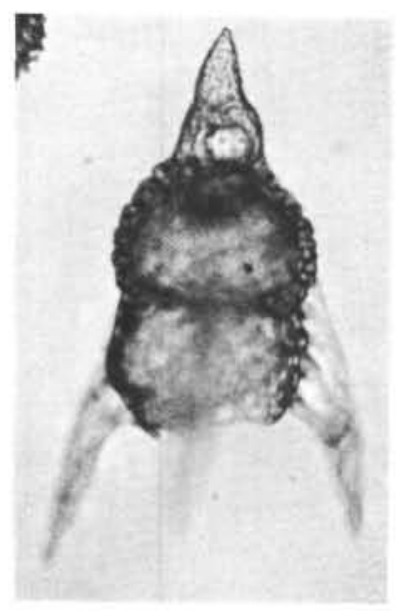

1

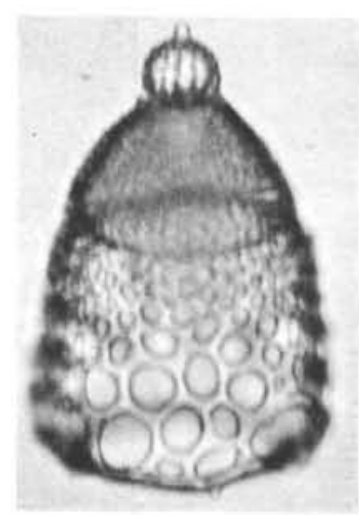

4

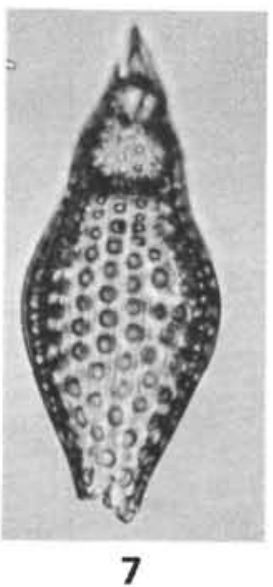

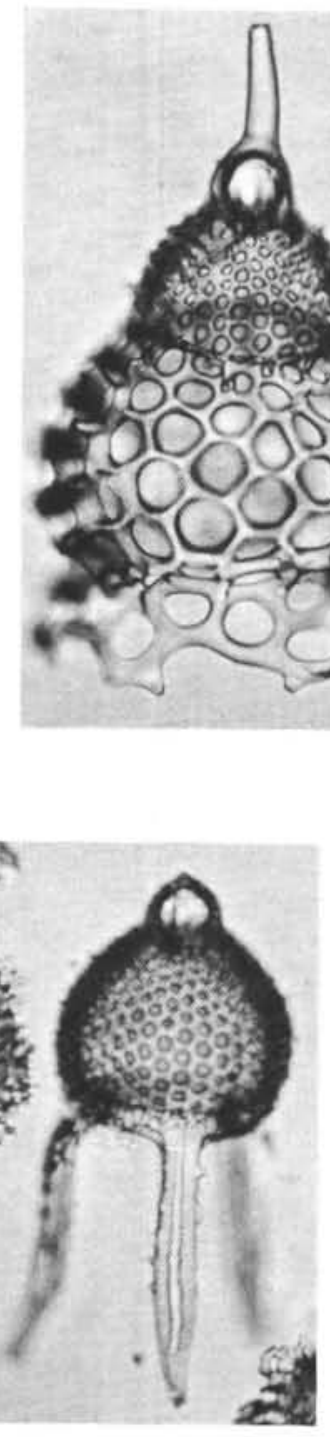

5
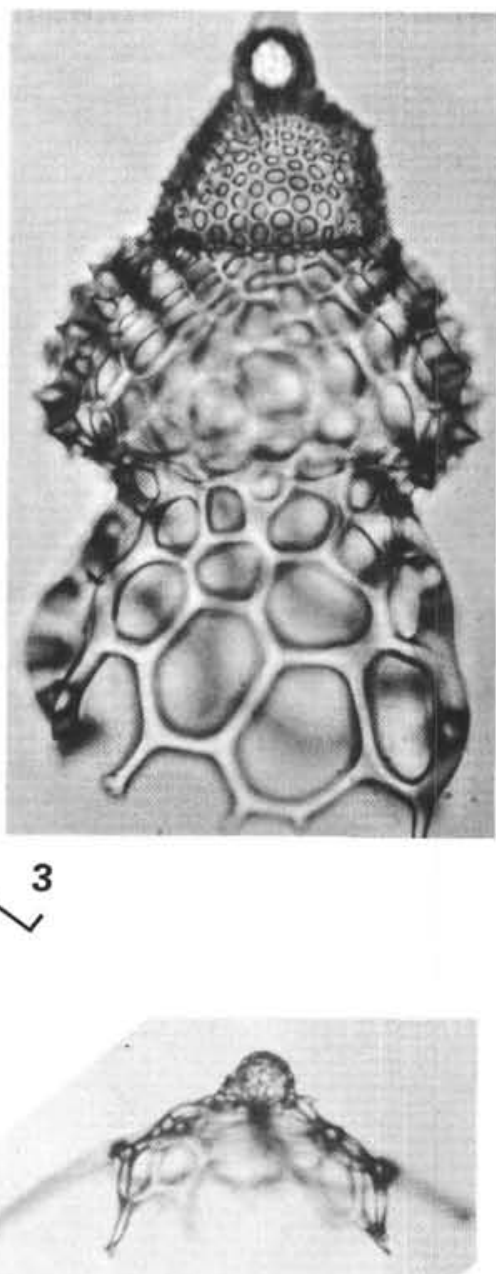

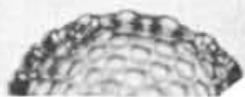

6

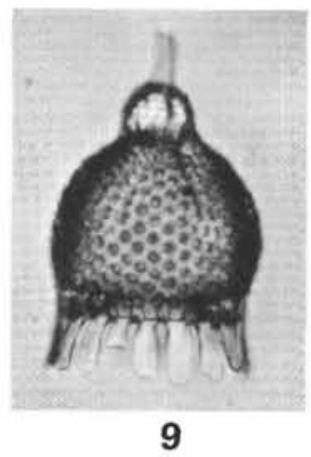

Plate 10. 
PLATE 11

Middle Eocene Radiolaria

Figure $1 \quad$ Podocyrtis papalis. 29-9-5, 112-114 cm. USNM 167304; Q 19/0; LHS.

Figure 2 Podocyrtis aphorma. 29B-10-4, 24-26 cm. USNM 167272; U 56/0; RHS. Holotype.

Figure 3 Podocyrtis sinuosa (?). 29-14-4, 102-104 cm. USNM 167300; U 42/2; RHS.

Figure $4 \quad$ Podocyrtis sinuosa (?). 29-12-3, 100-102 cm. USNM 167276; X 18/4; LHS.

Figure $5 \quad$ Podocyrtis mitra. 29-10-5, 120-122 cm. USNM 167268; E 18/4; LHS.

Figure 6 Podocyrtis mitra. 29-10-1, 78-80 cm. USNM 167165 ; S 41/3; RHS.

Figure 7 Podocyrtis trachodes. 29-10-1, 78-80 cm. USNM 167265; T 29/2; RHS. Holotype. 


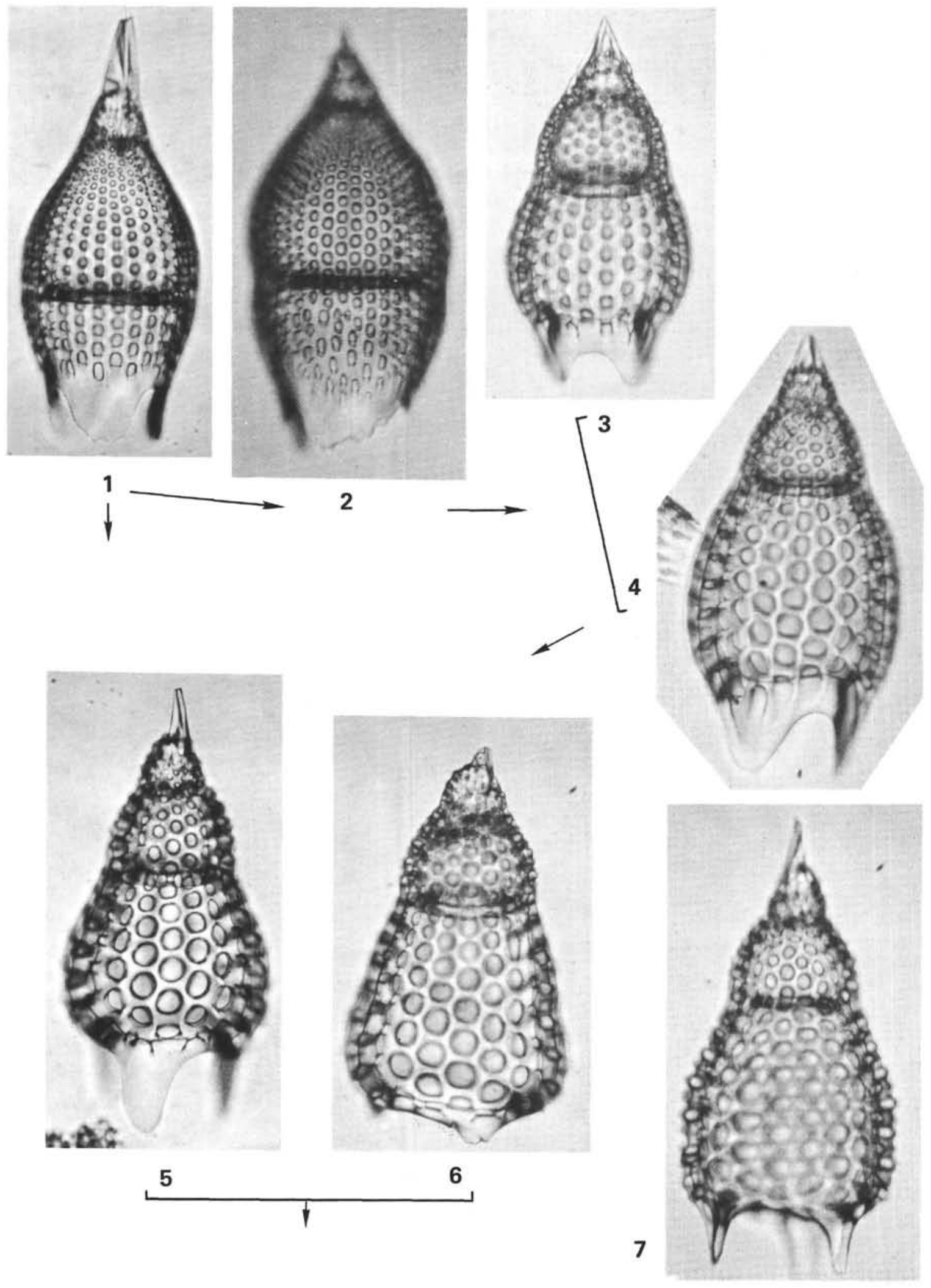

Plate 11. 
PLATE 12

Middle Eocene Radiolaria

Figure 1 Podocyrtis trachodes. 29-10-4, 100-102 cm. USNM 167302; 0 53/0; RHS.

Figures 2\&3 Podocyrtis chalara. 29B-8-4, 111-113 cm.

2: USNM $167305 ; \mathrm{C} 36 / 4$; LHS.

3: USNM 167305; K 52/4; RHS.

Figures 4\&5 Podocyrtis diamesa. 29-16-1, 116-118 cm. X 150.

4: USNM 167285; K 41/0; LHS.

5: USNM 167306; J 15/4; LHS.

Figure $6 \quad$ Podocyrtis diamesa. 29-15-3, 13-15 cm. X 150 . USNM 167307; M 53/1; LHS.

Figure 7 Podocyrtis ampla. 29-14-4, 102-104 cm. X 150. USNM 167308; X 23/4; LHS.

Figure $8 \quad$ Podocyrtis ampla. 29-10-5, 120-122 cm. X 150 . USNM 167309; B 16/3; LHS.

Figure 9 Theocampe mongolfieri. 29-12-3, 100-102 cm. USNM 167310; Y 22/1; LHS.

Figure 10 Gen. et sp. indet. 29-16-2, $90-92 \mathrm{~cm}$.

USNM 167311; Q 52/2; RHS. 

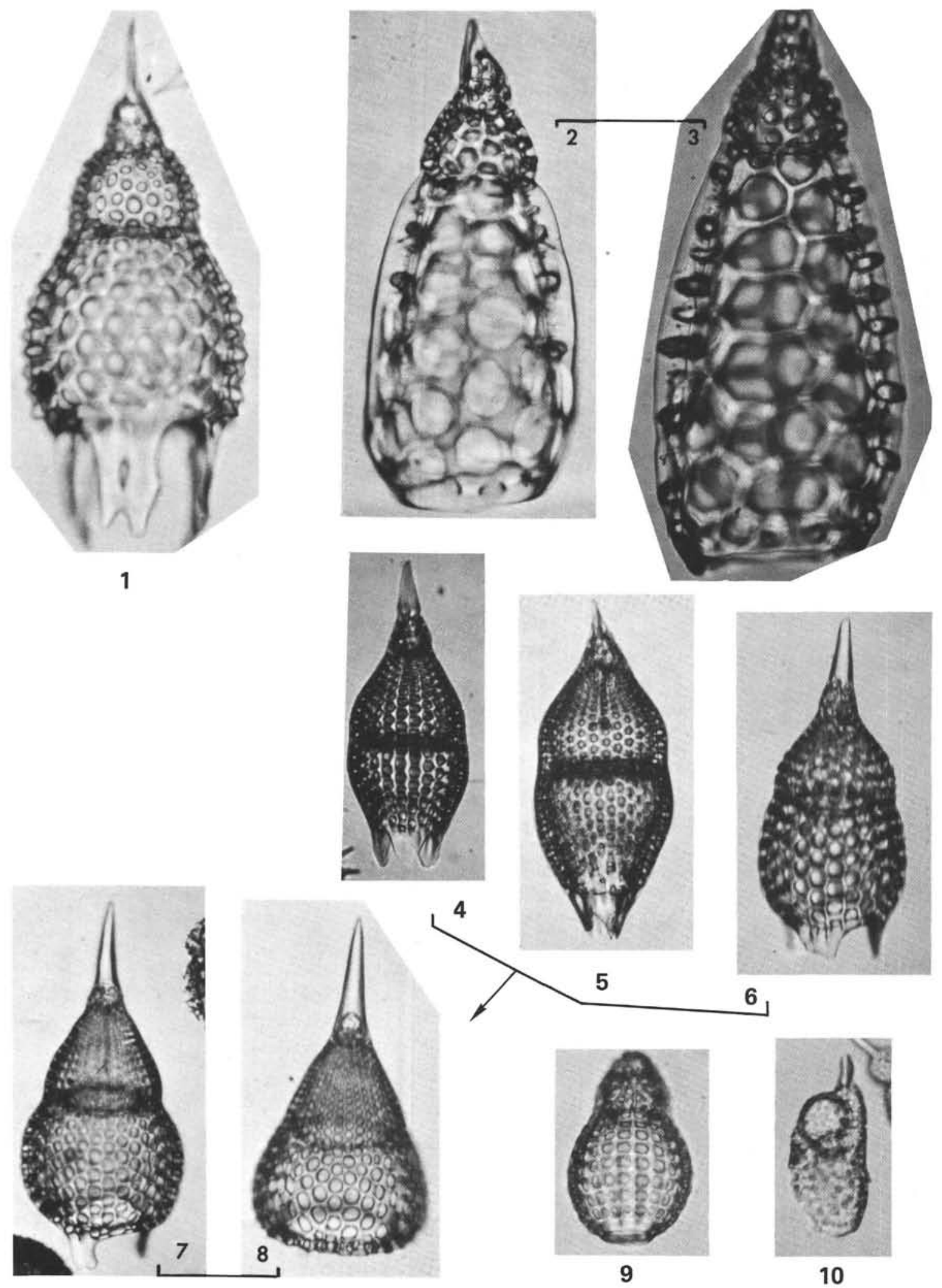

Plate 12. 
PLATE 13

Late Eocene and Oligocene Radiolaria

Figures 1\&2 Lithocyclia angustum. Bath Cliff, Barbados. 1: M-171; USNM 167312; E 34/1; RHS. 2: M-171; USNM 167312; V 34/0; RHS.

Figures 3\&4 Cycladophora turris. Bath Cliff, Barbados. 3: M-166; USNM 167313; Q 41/0; RHS. 4: M-167; USNM 167314; X 34/1; RHS.

Figure 5 Artophormis barbadensis. Bath Cliff, Barbados. M-163; USNM 167315; P 51/3; RHS.

Figures 6\&7 Artophormis gracilis. Bath Cliff, Barbados. 6: M-171; USNM 167312; L 45/3; RHS. 7: M-171; USNM 167312; N 25/0; RHS.

Figures 8,9\&10 Theocyrtis tuberosa. Bath Cliff, Barbados. (Figure 10 shows a fragment of the thorax, viewed along the axis of the shell.)

8: M-171; USNM 167312; O 42/2; RHS. 9: M-171; USNM 167312; C 46/0; RHS. 10: M-171; USNM 167312; F 44/3; RHS. 

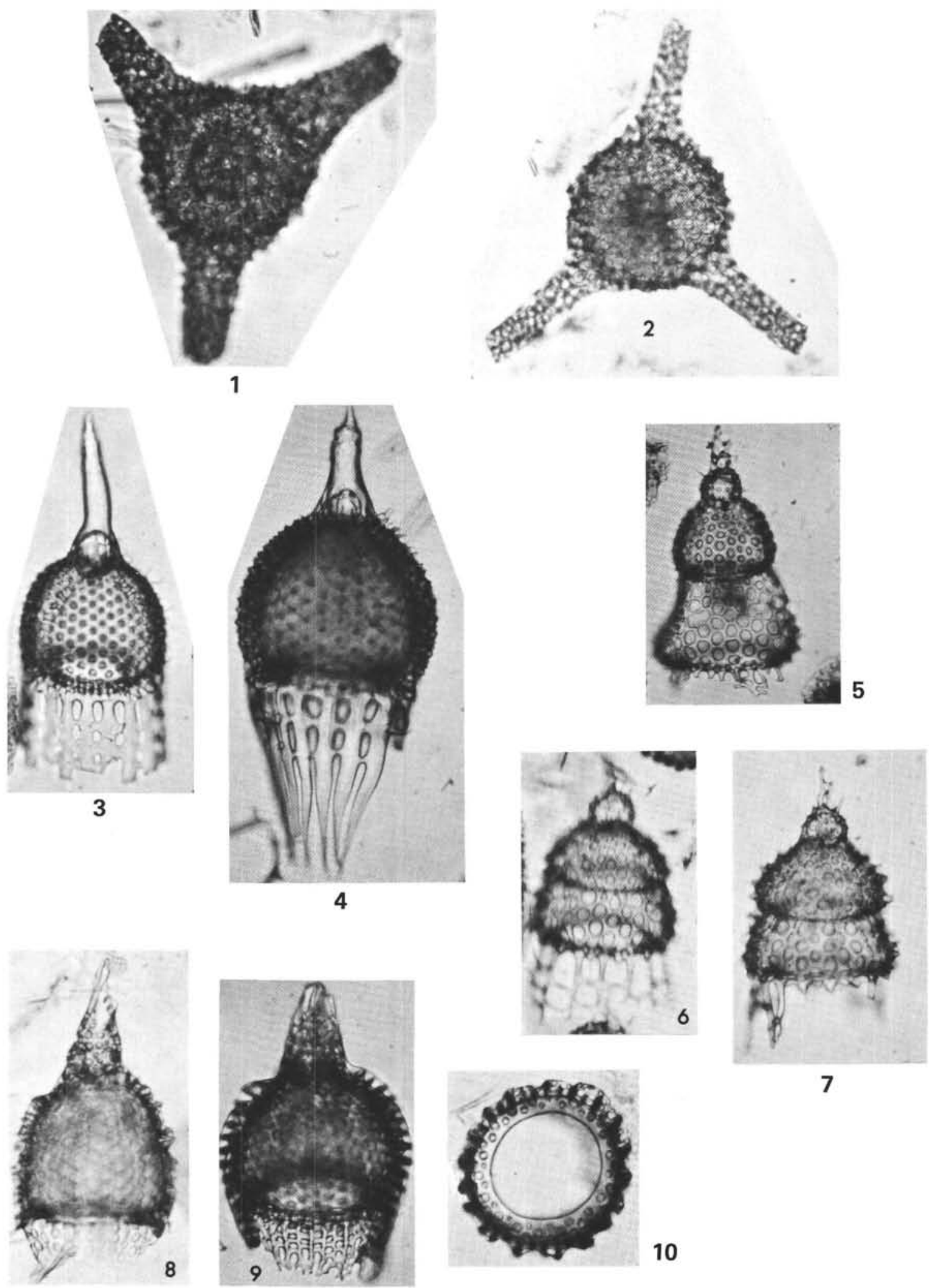

10

Plate 13. 
PLATE 14

Miocene Radiolaria

Figure 1 Cannartus mammiferus. Golconda, Trinidad (Rz. 554). USNM 167316; T 36/3; RHS.

Figure 2 Cannartus laticonus. AMPH 6P, 60-62 cm. USNM 167317; E 41/3; RHS. Holotype.

Figure 3 Cannartus (?) petterssoni. PROA 96P, $227-230 \mathrm{~cm}$. USNM 167318; G 33/2; RHS. Holotype.

Figure $4 \quad$ Ommatartus antepenultimus. AMPH 6P, $15-17 \mathrm{~cm}$. USNM 167319; G 27/3; RHS.

Figure $5 \quad$ Dorcadospyris alata. AMPH 91P, 243-245 cm. X 150. USNM 167320; U 31/2; RHS.

Figure 6 Stichocorys delmontense. AMPH 6P, 60-62 cm. USNM 167317; J 39/3; RHS.

Figure 7 Cyrtocapsella tetrapera. AMPH 6P, 60-62 cm. USNM 167317; G 34/2; RHS.

Figure $8 \quad$ Cyrtocapsella cornuta. WAH 7P, 257-259 cm. USNM 167321; N 49/0; RHS.

Figure 9 Cyrtocapsella japonica. AMPH 6P, 60-62 cm. USNM 167322; W 53/0; RHS.

Figure 10 Calocycletta virginis. AMPH 91P, $569.571 \mathrm{~cm}$. USNM 167323; K 40/0; RHS.

Figure $11 \quad$ Calocycletta cf. virginis. 31-9-Catcher. USNM 167324; F 41/0; RHS.

Figure 12 Calocycletta costata. AMPH 91P, $569-571 \mathrm{~cm}$. USNM 167325; L 38/2; RHS. 


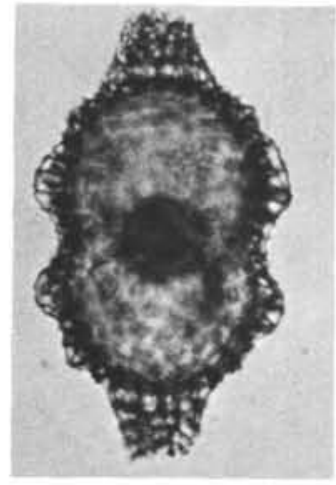

1

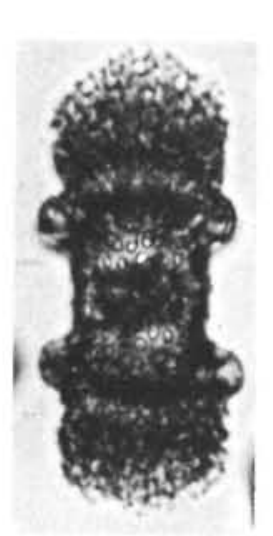

3
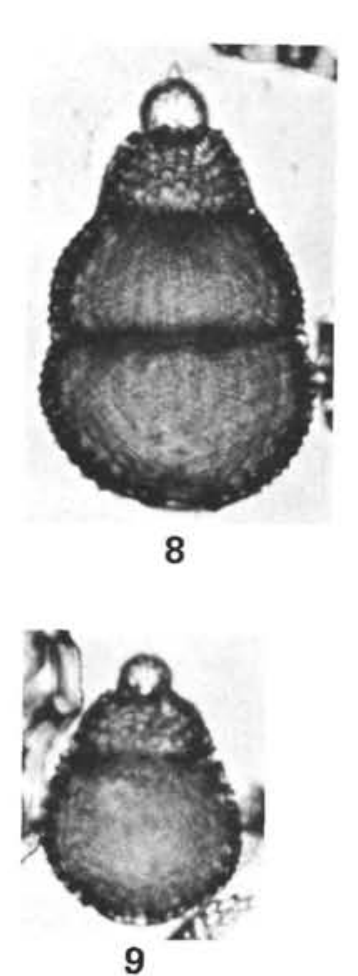
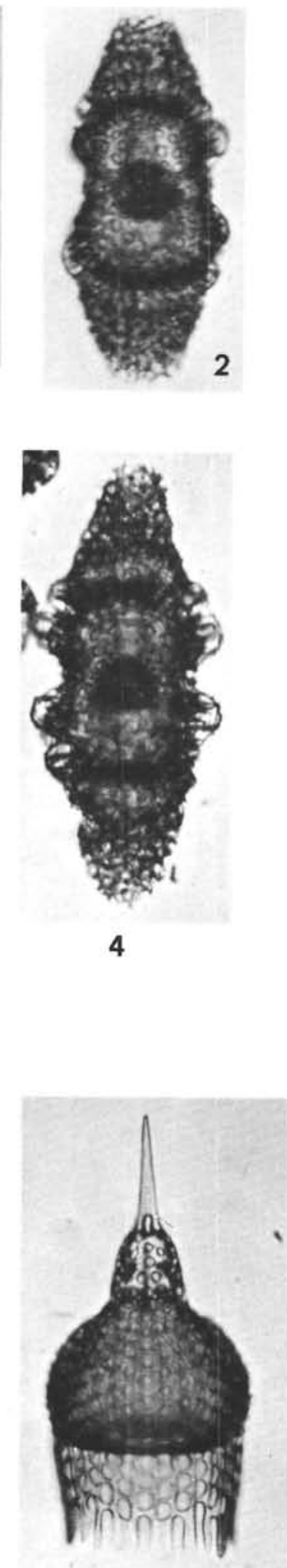

10
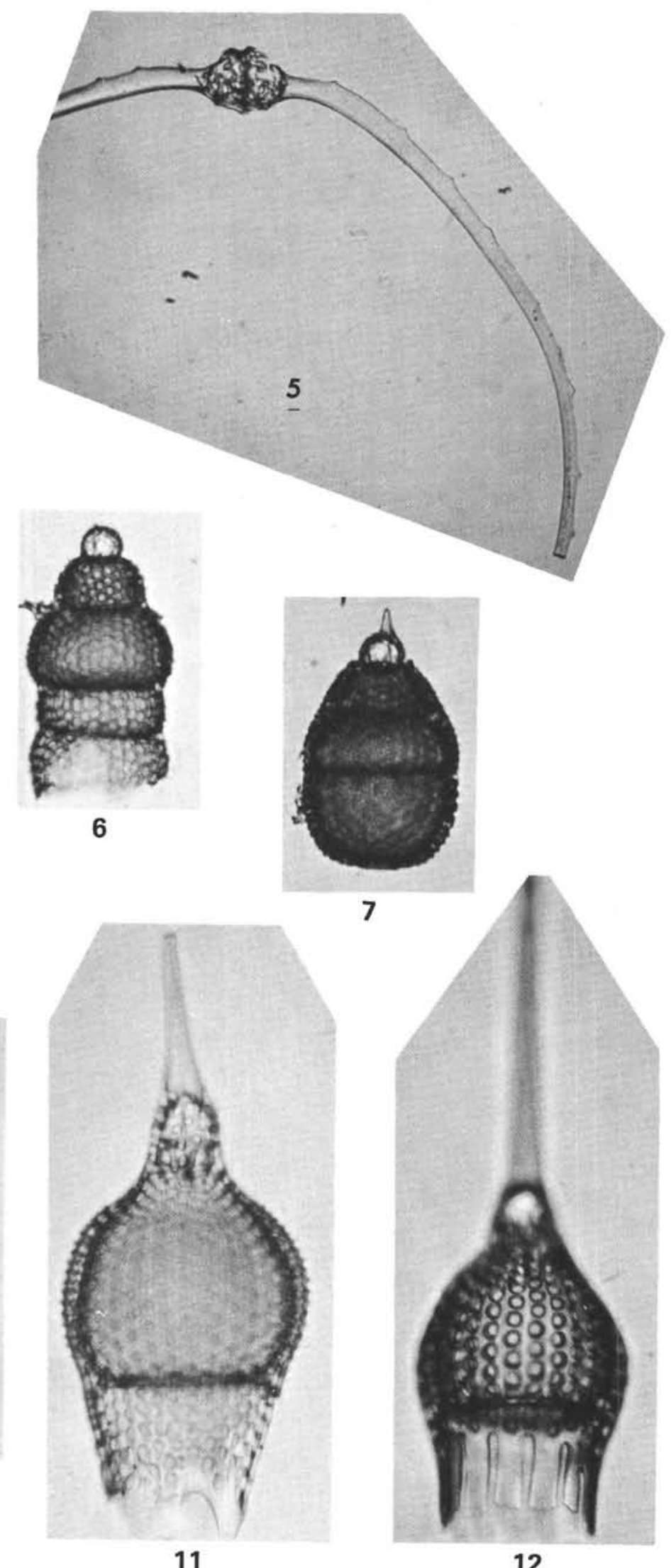

Plate 14. 
PLATE 15

Early Miocene and Pliocene Radiolaria

Figure 1 Cannartus prismaticus. 31-10-4. 0-3 cm. USNM 167326; T 50/3; RHS.

Figure 2 Cannartus tubarius. JYN V 20P. $457-459 \mathrm{~cm}$. USNM 167327; O 58/2; RHS.

Figure 3 Spongaster pentas. LSDH 78P. $520-522 \mathrm{~cm}$. USNM 167328; H 43/3; RHS. Holotype.

Figure 4 Dorcadospyris ateuchus. 31-10-4. 0-3 cm. X 150, USNM 167326; B 38/0; RHS.

Figure 5 Dorcadospyris papilio. $31-10-3.0-3 \mathrm{~cm} . \times 150$, USNM 167329; D 17/2; LHS.

Figure 6

Dorcadospyris simplex. 31-9-3. 0-4 cm. X 150, USNM 167330; F 57/4; RHS.

Figure 7 Dorcadospyris forcipata. $31-10-4.0-3 \mathrm{~cm} . \times 150$, USNM 167331; R 44/4; RHS.

Figure 8 Lychnocanium bipes. 31-9-Catcher. USNM 167324; L 34/3; RHS.

Figure 9 Theocyrtis annosa. 31-10-5. 0-3 cm. USNM 167332 ; X 58/0; RHS. 

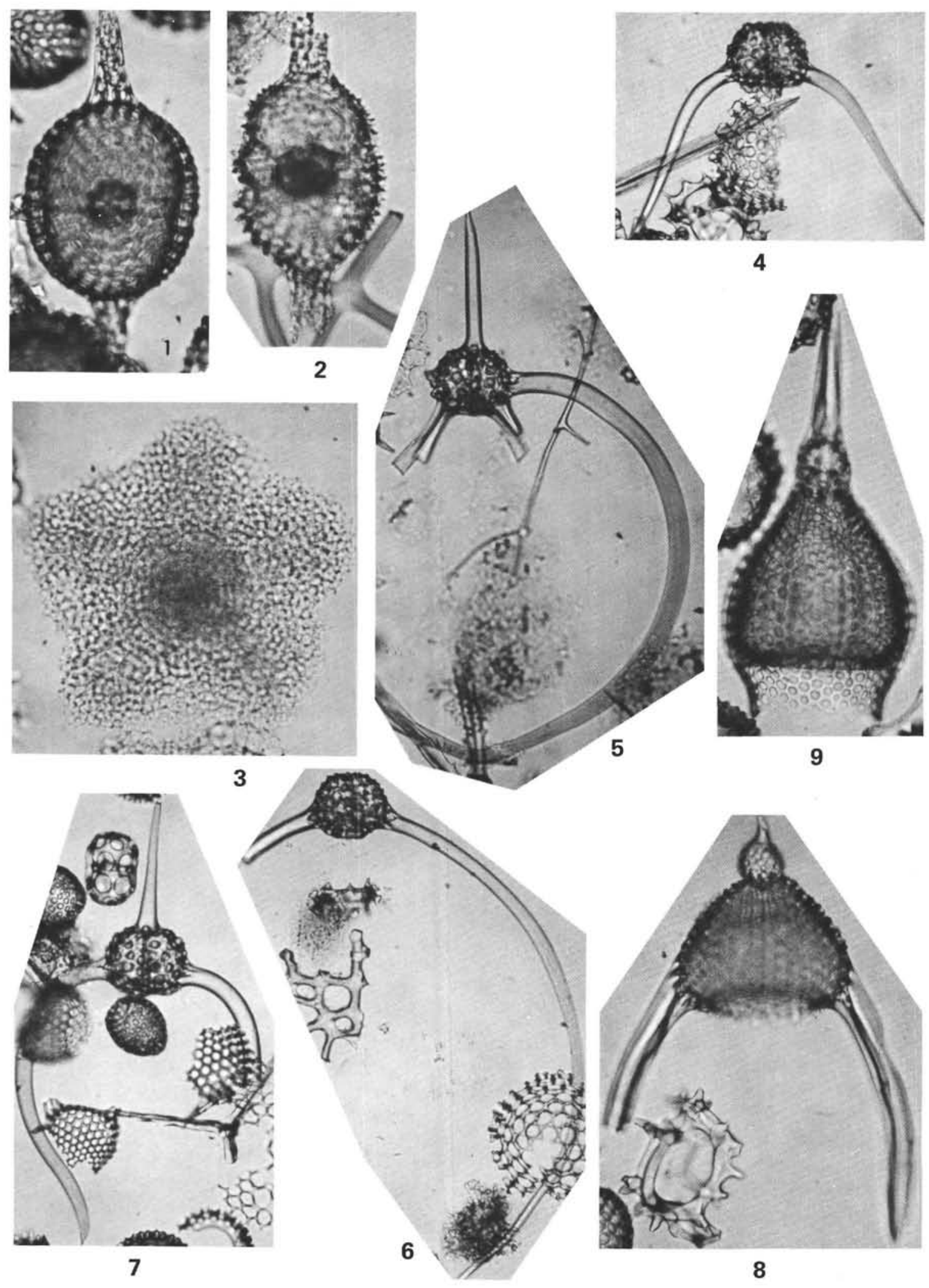

Plate 15. 


\section{INDEX OF RADIOLARIAN NAMES}

Only genus-group and species-group taxa are indexed. The principal references to thoroughly treated taxa are in italics.

Acerahedrina, 535

hirta, 535

Acerocanium, 535

globosum, 535

Acrobotrys, 542

monosolenia, 542

tritubus, 508; 512; 525;542

Alacorys lutheri, 540

Amphibrachium concentricum, 504; Pl. 1, Figs. 6, 7 ornatum, 504; Pl. 1, Figs. 4, 5

Amphipyndax, Pl. 3, Fig. 11 stocki, 505

Anthocyrtoma, 507; 511; 512; 523; 530; Pl. 6, Figs. 2, 3,4

Anthocyrtis hispida, 535 serrulata, 530

Artocapsa dunikowskyi, 537

Artophormis, 538 barbadiensis, 507; 508; 524; 538; 543; P1. 13, Fig. 5 dominasinensis, 507; 538

gracilis, 507; 508; 512; 523; 538; 543; P1. 13 Figs. 6, 7 horrida, 538

Astractinium, 528

Astractura, 528 ordinata, 528

Astrococcura, 528 concinna, 528

Astrocyclia, 528 solaster, 528

Astromma aristotelis, 528 pentactis, 528 pythagorae, 528

Brachiospyris alata, 529 simplex, 529

Calocyclas, 535 barbadiensis, 538 casta, 530 turris, 535 veneris, 541

Calocycletta, 541 costata. $508 ; 512 ; 525 ; 540 ; 543 ;$ Pl. 14 , Fig. 12 virginis, 508; 512; 524; 525; 540; 543; Pl. 14, Figs. 10, 11

Calocycloma, 530

(?) ampulla, 507; 511; 512; 523; 530; Pl. 6, Fig. 1 Cannartidium mammiferum, 526

Cannartus, 526 laticonus, 508; 512; 525; 526; 542; Pl. 14, Fig. 2 mammiferus, $508 ; 512 ; 525 ; 526 ; 542 ;$ Pl. 14, Fig. 1 (?) petterssoni, 508; 512;525;526; 542; P1. 14, Fig. 3 prismaticus, 508; 512; 524; 526; 542; Pl. 15, Fig. 1 tubarius, 508; 512; 524; 526; 542; P1. 15, Fig. 2 violina, $508 ; 512 ; 524 ; 525 ; 526 ; 542$

Cantharospyris ateuchus, 529

Ceratospyris ateuchus, 529

Clathrocyclas dominasinensis, 538

Coccocyclia, 528

Cormutella, 505

sp., Pl. 3, Fig. 3

circularis, 526

mitra, 526

Cycladophora, 535

enneapleura, 529

goetheana, $540 ; 541$

hexapleura, 540

hispida, 507; 511; 523; 535; 543; Pl. 10, Fig. 9 stiligera, 535

turris, 507; 523; 535; 543; Pl. 13, Figs. 3, 4

Cyrtocalpis fabaeforme, 529

Cyrtocapsa bicornis, 537

brevicornis, 537

compacta, 537

hirta, 537

macropora, 537

marinelli, 537

miocenica, 537

miocenica imperforaticauda, 537

miocenica laevicauda, 537

poligonalis, 537

pyrum, 537

rothpletzi, 537

strangulata, 537

subconica, 537

tetrapera, 536

Cyrtocapsella, 536

cornuta, 508; 512; 524; 528; 537; P1. 14, Fig. 8 elongata, $508 ; 512 ; 524 ; 525 ; 537$

japonica, 508; 512; 524; 525; 538; Pl. 14, Fig. 9

Tetrapera, 508; 512; 524; 525; 536; P1. 14, Fig. 7

Dicolocapsa elongata, 538

verbeeki, 505; Pl. 3, Fig. 2

Dictyomitra, 505

spp., 505; Pl. 3, Figs. 8-10

ehrenbergi, 541

uralica, 505

Dictyophimus, 533 
babylonis, 534

craticula, 525; Pl. 10, Fig. 6

crisiae, 533; 534

(?) tethyis, 534

Dictyopodium, 536

eurylophos, 537

Dipodospyris forcipata, 529

Dipospyris forcipata, 529

Dorcadospyris, 529

alata, 508; 512; 524; 525; 529; 542; Pl. 14, Fig. 5

ateuchus, 508; 512; 524; 529; 542; Pl. 15, Fig. 4

dentata, 508; 512;524; 525;529; 542

forcipata, 508; 512; 524; 525; 529; Pl. 15, Fig. 7

papilio, 508; 512; 524; 529; Pl. 15, Fig. 5

simplex, 508; 512; 524; 525; 529; 542; Pl. 15, Fig. 6

Dorysphaera, 526

\section{Eribotrys, 542}

Euchitonia triradiata, 505; Pl. 2, Fig. 3

Eucyrtidium ampulla, 525

ampullus, 525; 530

apiculatum, 538

barbadense, 541

cryptocephalum, 531

delmontense, 536

elongatum peregrinum, 536

ficus, 531

fistuligerum, 533

globicephalum, 537

ichikawai, 537

isseli, 537

lagenoides, 536; 537

mongolfieri, 542

sipho, 533

stephenophorum, 535; 536

tubulus, 533

turgidulum, 536

typus, 537

Eusyringium, 533

conosiphon, 533

curvispina, 536

fistuligerum, 506; 507; 511; 512; 520; 521; 522;

523; 533; 543; Pl. 8, Figs. 8, 9

haeckelianum, 537

isozakiense, 538

japonicum, 538

lagena (?), 506; 511; 520; 521; 522; 533; 543; P1. 8,

Figs. 5, 6, 7

marianii, 537

nipponicum, 537

oligoporum, 537

sipho, 533

yatsuoense, 537

Eusyringoma, 536

Giraffospyris didiceros, 529; Pl. 5, Figs. 3, 4, 5

Gongylothorax verbeeki, 505
Halioomma triactis, 527

Hexaspyris papilio, 529

Holocryptocapsa, 505

Hymenactinium, 528

Hymenactura, 528

archimedis, 528

copernici, 528

Hymeniastrum, 528

pythagorae, 528

Lamprodiscus, 535 monoceros, 535

Lampterium, 540; 543

Lamptidium, 540

Lamptonium, 529; 530

(?) fabaeforme (?) chaunothorax, 506; 511; 520; 521; 522; 530; ; Pl. 5, Figs. 8, 9

(?) fabaeforme (?) constrictum, 506; 511; 520;521; 522; 529; P1. 5 , Fig. 7

(?) fabaeforme fabaeforme (?), 506; 511; 520; 521; 522; 529; Pl. 5, Fig. 6

Lithapium, 526

(?) anoectum, 506; 511; 520; 521; 522; 526; 542;

P. 4. Figs. 4, 5

(?) mitra (?), 506; 507; 511; 520; 521; 522; 526;

542; Pl. 4, Figs. 6, b7

(?) plegmacantha, 506; 511; 520; 521; 522; 526;

Pl. 4, Figs. 2, 3

pyriforme, 526

Lithocampe hirundo, 535

micropyle, 537

turgida, 539

Lithocampium, 539

sp., 506; 520; 521; 522; 539; P1. 10, Fig. 8

stabile, 539

Lithochytris, 544

archaea, 506; 511; 520; 521; 522; 534; 543; Pl. 9, Fig. 7

barbadiensis, 534

cheopsis, 534

lucerna, 534

vespertilio, 506; 507; 520; 521; 522; 529; 533; 534;

543; Pl.9, Figs. 8, 9

Lithocyclia, 528

angustum, 508; 512; 523; 524; 528; 542; Pl. 13, Figs. 1, 2

aristotelis group, 507; 528; 543

ocellus, 528

ocellus group, 507; 520; 521; 522; 523; 528; 533; 542;

545; Pl. 5, Figs. 1, 2 stella, 528

Lithopera lagena, 533

Lithornithium, 535

Lophocyrtis, 535

(?) jacchia, 507; 536

Lychnocanium, 535

bellum, 506; 507; 512; 520; 521; 522; 523; 535; Pl. 10, Fig. 5 
bipes, 508; 512; 524; 535; Pl. 15, Fig. 8 clavigerum, 535

falciferum, 535

lucerna, 533

Lychnocanoma, 535

Monostylus, 526

Ommatartus, 527

amphicanna, 527

antepenultimus, 508;512;524;525;527; 542; Pl. 14, Fig. 4

hughesi, 508; 512; 519;527; 542

penultimus, 508; 512; 519;527; 542

tetrahaltmus, 542

Ommatocampe hughesi, 527

Panarium antepenultimum, 527

penultimum, 527

Pentactura, 528

Phacotriactis, 527

triangula, 527

Phormochytris, 538

annosa, 541

longicornis, 538

Phormocyrtis striata, 506; 520; 521; 522; 538; P1. 10, Fig. 7

Pipettella prismatica, 526

Pipettaria tubaria, 526

Pleuropodium, 535

Podocampe yatsuoensis, 537

Podocyrtarium, 531

Podocyrtidium, 539

Podocyrtis, 539

aculeata, 533

amphiacantha, 536

ampla, 506;511;520;521;539; 543; P. 12, Figs. 7, 8 aphorma, 506; 511; 520; 521; 522; 525; 540; 543;

Pl. 11, Fig. 2

brevipes, 538

chalara, 506; 511; 512; 520; 521; 522; 541; 543;

Pl. 12, Figs. 2, 3

charybdea, 535

cothurnata, 532

diamesa, 506; 511; 520; 521; 522; 539; 543; Pl. 12 ,

Figs. 4, 5, 6

dominasinensis, 538

eulophos, 540

fasciata, 539

goetheana, 507; 512;541;543

hirsutus, 532

mitra, 506; 507; 511; 512; 520; 521; 522; 523;540,

543; P. 11, Figs. 5, 6

papalis, 506;507; $512 ; 520 ; 521 ; 522 ; 523 ; 525 ; 257$;

539; 543; Pl. 11, Fig. 1

pedicellaria, 540

pentacantha, 533

princeps, 532 radicata, 532

rhizodon, 531

schomburgkii, 532

sinuosa, 506; 511; 520; 521; 522; 525; 540; 543;

Pl. 11, Figs. 3, 4

tetracantha, 533

trachodes, 506;511;520;521;522; 541; 543; Pl. 11,

Fig. 7; Pl. 12, Fig. 1

triacantha, 532

tripodiscus, 531

Podocyrtonium, 540

Pseudoaulophacus gallowayi, 505; Pl. 2, Fig. 5

Pterocanidium, 535

Pterocanium, 535

eucolpum, 535

prismatium, 508; 519; 535

proserpinae, 535

Saturnalis minimus, 504; Pl. 1, Fig. 2

Sciadiocapsa, 505; Pl. 3, Figs. 6, 7

Septinastrum dogeli, 505; P1. 2, Fig. 1

Sethamphora mongolfieri, 542

Sethocapsa, 533

lagena, 533

pyriformis, 533

Sethochytris, 533

babylonis group, 506; 507; 520; 521; 522; 523; 534;

543; Pl. 9, Figs. 1, 2, 3

triconiscus (?), 506; 511; 520; 521; 522; 523; 533; 534; 543; Pl. 9, Fig. 6

Spongaster, 528

pentas, 508; 519; 529; Pl. 15, Fig. 3

tetras, $528 ; 529$

Spongatractus pachystylus, 525; Pl. 4, Fig. 1

Spongopyle insolita, 505; Pl. 2, Fig. 2

Stichocapsa brevicauda, 537

elongata, 537

hexagona, 537

hirta, 537

laevigata, 537

longicauda, 537

macropora, 537

strangulata, 537

Stichocorys, 536

delmontense, 508; 512; 519; 515; 536; 543; Pl. 14, Fig. 6

peregrina, $508 ; 512 ; 519 ; 536 ; 543$

wolffii, $508 ; 512 ; 524 ; 525 ; 536$;

Syringium, 536

vinassai, 536; 537

Tetralacorys, 540

Theocampe, 541, 542

sp. Pl. 3, Fig. 12

mongolfieri, 505; 506; 507; 511; 520; 521; 522; 533; 542; Pl. 12, Fig. 9

Theocapsa cayeuxi, 538

elongata, 537 
himiensis, 538

piriformis, 537

salva, 505

Theocapsomma, 505; Pl. 3, Fig. 1

Theocorys, 530; 531; 536

anaclasta, 506; 511; 520; 521; 522; 525; 536; P1. 10,

Figs. 2, 3

anapographa, 506; 511; 520; 521; 522; 536; Pl. 10, Fig. 4

morchellula, 536

veneris, 536

Theocorythium, 530

Theocotyle, 530

cryptocephala cryptocephala (?), 506; 511; 520; $521 ; 522 ; 525 ; 531 ; 543$; Pl. 6, Figs. 7, 8

cryptocephala (?) nigriniae, 506;511; 520; 521; 522;

$527 ; 530 ; 531 ; 543 ;$ Pl. 6, Figs. 5, 6

(?) ficus, 506; 507; 512; 520; 521; 522; 523; 525; $530 ; 531$; Pl. 7, Figs. 3, 4, 5

venezuelensis, 506; 511; 520; 521; 522; 525; 530; 531; Pl. 6, Figs. 9, 10; Pl. 7, Figs. 1, 2

Theocyrtis, 541

annosa, 508; 512; 524; 541; Pl. 15, Fig. 9

tuberosa, 507; 508; 523; 524; 541; P1. 13, Figs. 8, 9,10

"Theodiscus" superbus, 505

Theosyringium tubulus, 533

Thyrsocyrtis, 531 bromia, 507; 512; 531; 532; 543

dionysia, 536

hirsuta, $531 ; 543$

hirsuta hirsuta, 506; 511; 520; 521; 522; 527; 532;

Pl. 7, Figs. 8, 9

hirsuta robusta, 506; 511; 520; 521; 523; 525; 532,

Pl. 8 , Fig. 1

jacchia, 536

rhizodon, 506; 507; 520; 521; 522; 523; 525; 531;

543; P. 8, Fig. 1

rhizopus, 531

tetracantha, 507; 512; 531, 533, 543

triacantha, 506; 507; 511; 520; 521; 522; 523; 531;

532; 543; Pl. 8, Figs. 2,3

Triactis, 527

tripyramis triangula, 506; 520; 521; 522; 527; 542;

Pl. 4, Figs. 9, 10

tripyramis tripyramis, 506; 511; 520; 521; 522; 527;

542; Pl. 4, Fig. 8

Triactiscus, 527

tripodiscus, 527

tripyramis, 527

Triactoma, 527

Tricolocapsa elliptica, 537

granti, 505

hexagonata, 537

Trigonactura angusta, 528

Tristylospyris triceros, 543 